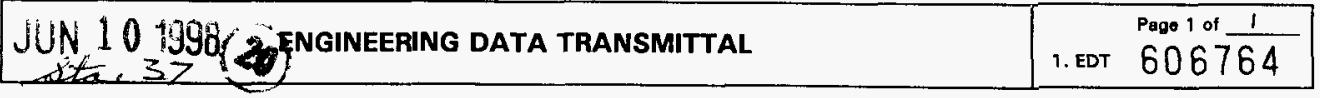

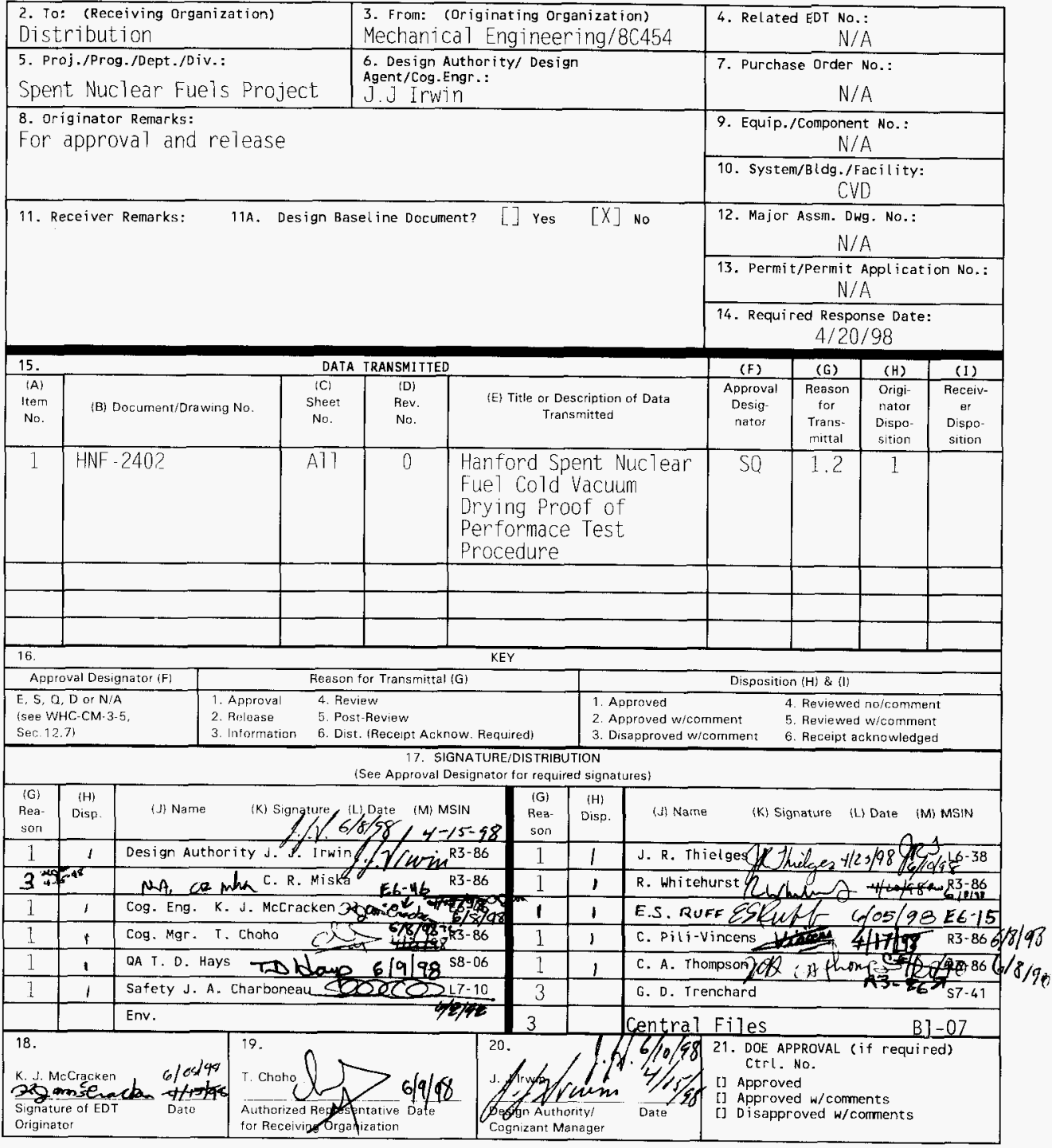

BD- $7400-172-2(05 / 96)$ GEF097 


\section{Hanford Spent Nuclear Fuel Cold Vacuum Drying Proof of Performance Test Procedure}

Kurt J. McCracken

Fluor Daniel Northwest. Richland. WA 99352

U.S. Department of Energy Contract DE-AC06-96RL 13200

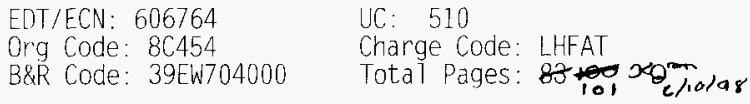

Key WordS: SPENT NUCLEAR FUEL, COLD VACUUM DRYING. FIRST ARTICLE TESTING. TEST PROCEDURE, $W-441$

Abstract: This document provides the test procedure for cold testing of the first article skids for the Cold Vacuum Drying (CVD) process at the $306 \mathrm{E}$ Facility. The primary objective of this testing is to confirm design choices and provide data for the initial start-up parameters for the process. The current scope of testing in this document includes design verification. drying cycle determination, equipment performance testing of the CVO process and MCO components, heat-up and cool-down cycle determination, and thermal model validation.

TRADEMARK DISCLAIMER. Reference herein to any specific commercial product, process, or service by trade name, trademark, manufacturer, or otherwise, does not necessarily constitute or imply its endorsement, recomendation, or favoring by the United States Government or any agency thereof or its contractors or subcontractors.

Printed in the United States of America. To obtain copies of this document, contact: Document Control Services, P.O. Box 950, Mailstop H6-08, Richland Wa 99352, Phone (50́9) 372-2420;

Fax (509) $376-4989$.
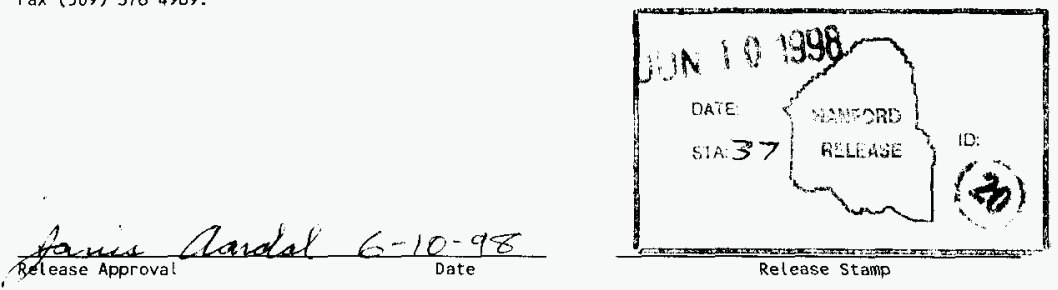

Approved for Public Release 


\section{HANFORD SPENT NUCLEAR FUEL COLD VACUUM DRYING PROOF OF PERFORMANCE TEST PROCEDURE}

Spent Nuclear Fucl Project

First Article Testing (LHFAT)

Prepared by

Numatec Hanford Corporation

P.O. Box 1300

Richland, Washington

by

Kurt J. McCracken, Engr. I

Spent Nuclear Fuel, Fluor Daniel Northwest

and

E.A. Smith, Engr. I

Fluor Daniel Northwest with

Technical Contributors

J. J. Irwin, Design Authority

Cold Vacuum Drying Facility, Numatec Hanford Company

C. R. Miska, Process Engineer

Cold Vacuum Drying Facility, Numatec Hanford Company

B.C. Fryer, Consulting Engineer

Thermal Analysis, John Marvin Incorporated

R. Whitchurst, Design Authority

Cold Vacuum Drying Facility, DESH

for

Duke Engineering Services Hanford

P.O. Box 1970

Richland, WA 99352 
HNF-2402

Rev. 0

HANFORD SPENT NUCLEAR FUEL COLD VACUUM DRYING PROOF OF PERFORMANCE TEST PROCEDURE

Spent Nuclear Fuel Project

First Article Testing (LHFAT)

Prepared by

Numatec Hanford Corporation

P.O. Box 1300

Richland, Washington

by

Kurt J. McCracken, Engr. I

Spent Nuclear Fuel, Fluor Daniel Northwest

and

E.A. Smith, Engr. I

Fluor Daniel Northwest

Prepared by: 20 rom Echadea

K. J. McCracken

$\frac{6 / 4 / 98}{\text { Date }}$

Numatec Hanford Corporation
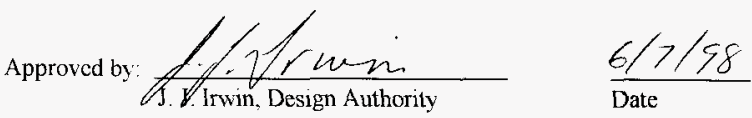

Independent Review

Approved by:
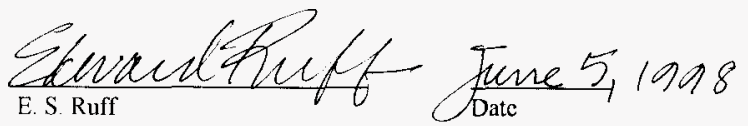

ii 
HNF-2402

Rev. 0

\section{INDEPENDENT REVIEW}

Document Reviewed Hanford Spent Nuclear Fuel Cold Vacuum Drying Proof of Performance Test Procedure

Author K. J. McCracken Report No. HNF-2402 EDT No. $\underline{606764}$

The subject document has been reviewed by the undersigned. The reviewer reviewed and verified the following items as applicable [HNF-PRO-445].

- Engincering Specification

- Design Input

- Basic Assumption

- Approach/Design Methodology

- Related Information

- Conclusion/Result Interpretation
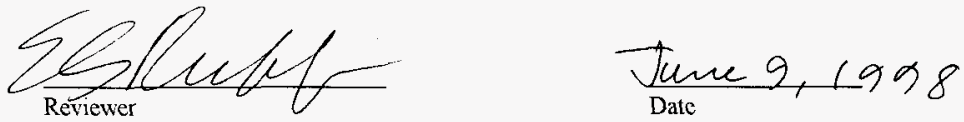


\section{TABLE OF CONTENTS}

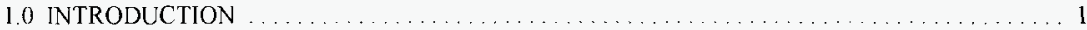

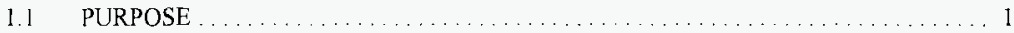

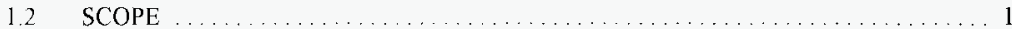

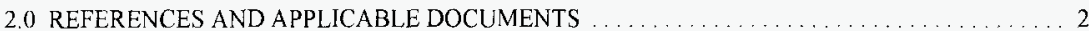

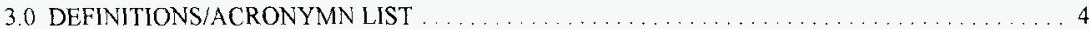

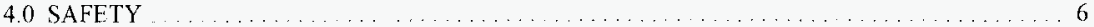

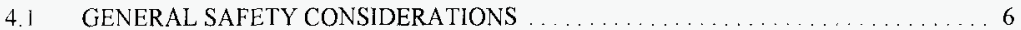

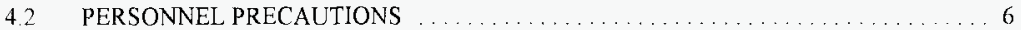

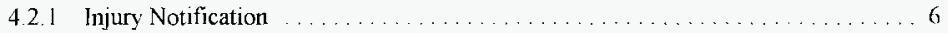

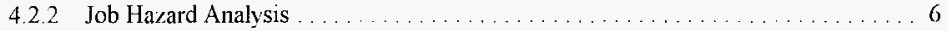

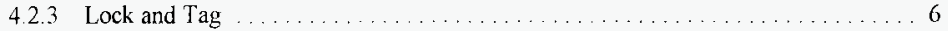

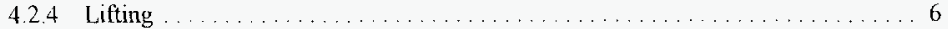

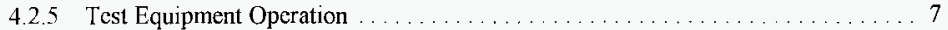

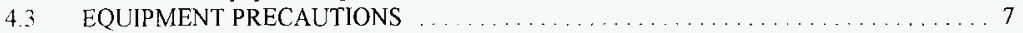

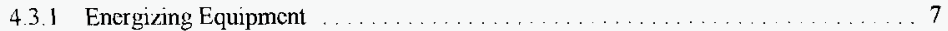

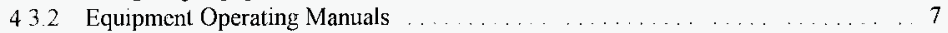

5.0 ORGANIZATION RESPONSIBILITIES, AUTHORITY, AND ADMINISTRATION _..... 7

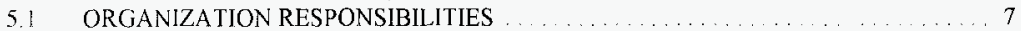

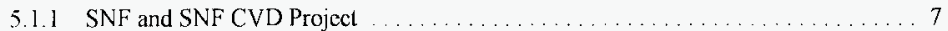

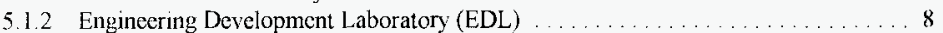

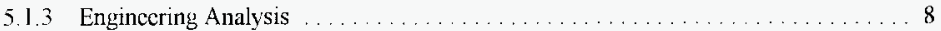

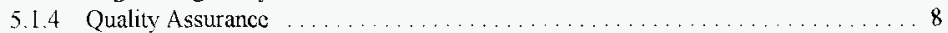

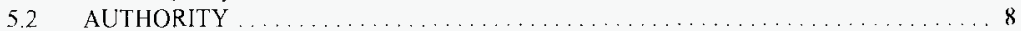

5.2.1 Project Design Management and Design Authority ................. 8

5.2 .2 Test Director . . . . . . . . . . . . . . . . . . . . . . . . 8

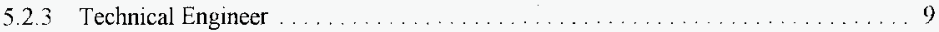

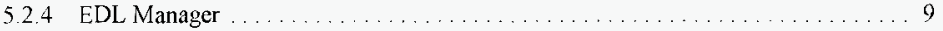

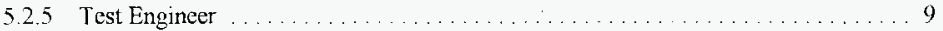

5.26 Test Performers/Operators . . . . . . . . . . . . . . . . . . . . . . . 9

5.2 .7 Test Review Board . . . . . . . . . . . . . . . . . . . . . . . . . . . . . 9

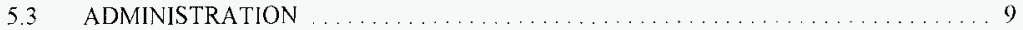

5.3 .1 Tagouts ........................................... 9

5.3 .2 Test Changes . . . . . . . . . . . . . . . . . . . . . . . . . . . . 10

5.3 .3 Acceptance Criteria . . . . . . . . . . . . . . . . . . . . . . 10

5.3 .4 Test Validity . . . . . . . . . . . . . . . . . . . . . . . . . . . . 10

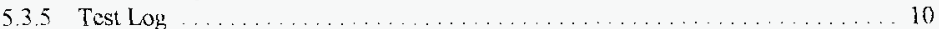

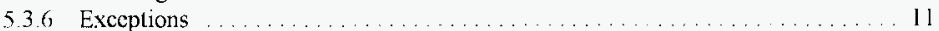

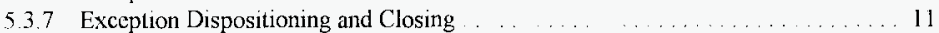

5.3 .8 Signatures .. . . . . . . . . . . . . . . . . . . . . . . . . . . . 11

5.3 .9 Repeat Testing . . . . . . . . . . . . . . . . . . . . . . . 11

5.3.10 Test Configuration Control ......................... 11

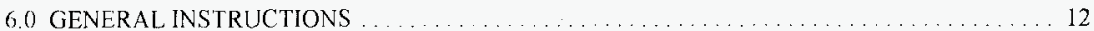

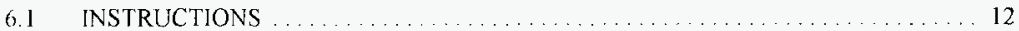

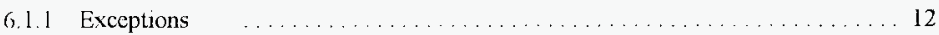




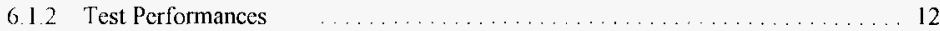

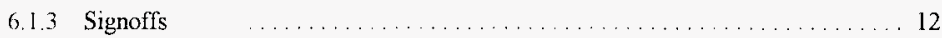

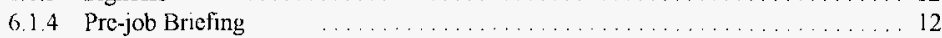

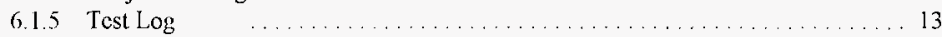

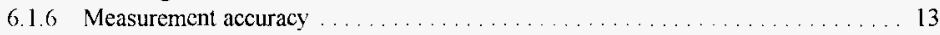

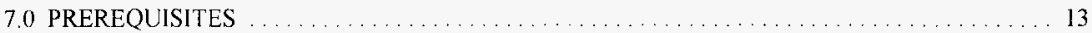

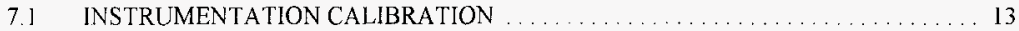

7.2 ADDITIONAL INSTRUMENTATION CALIBRATIONS $\ldots \ldots \ldots \ldots \ldots \ldots \ldots \ldots$

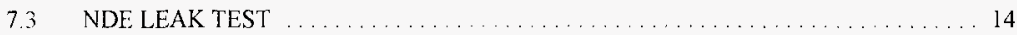

7.4 PRE-JOB SAFETY BRIEFING $\ldots \ldots \ldots \ldots \ldots \ldots \ldots \ldots \ldots \ldots \ldots \ldots \ldots \ldots$

8.0 TEST APPARATUS SET-UPS AND PRE-TEST PERFORMANCES $\ldots \ldots \ldots \ldots \ldots \ldots \ldots \ldots$

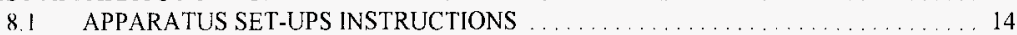

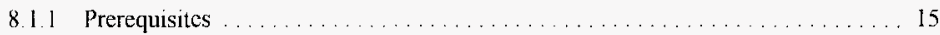

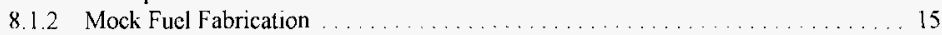

8.1.3 Equipment Performance Testing Apparatus (First Article Test Bed) . . . . . . 15

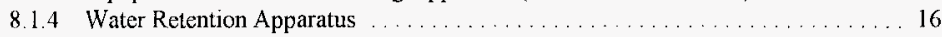

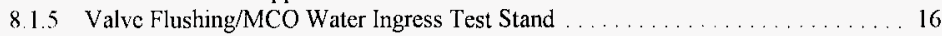

8.2 PRE-TEST PARAMETER ESTABLISHMENT $\ldots \ldots \ldots \ldots \ldots \ldots \ldots \ldots \ldots \ldots \ldots$

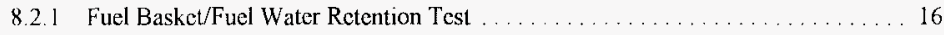

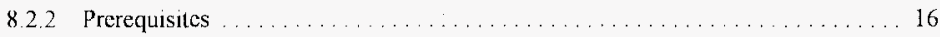

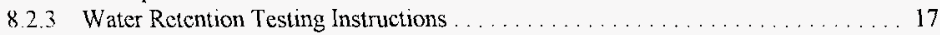

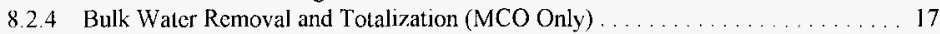

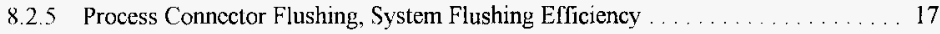

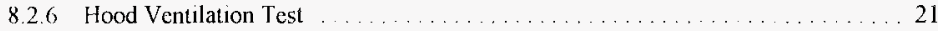

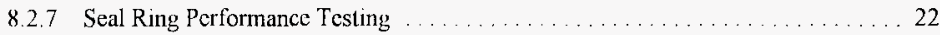

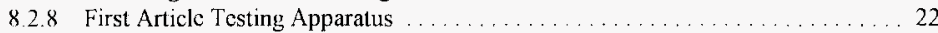

8.2.9 MCS Computer Control Setup and Testing .................. 23

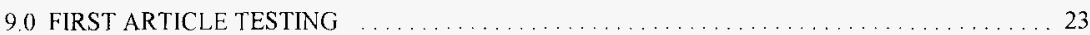

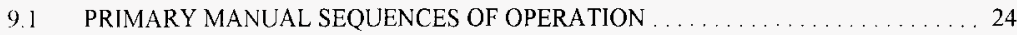

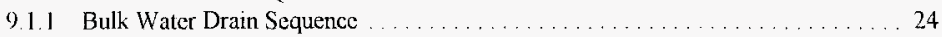

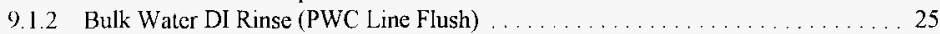

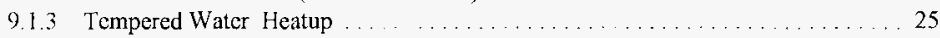

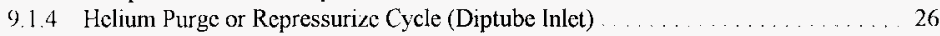

9.1 .5 Vacuum Drying with Condenser ......................... 26

9.1.6 Vacuum Drying without Condenser . . . . . . . . . . . . . . . . . 26

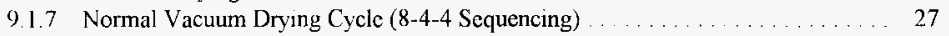

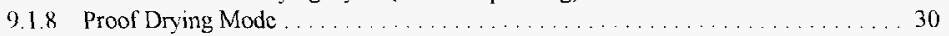

9.1 .9 MCO Cooling . . . . . . . . . . . . . . . . . . . . . . . 30

9.1 .11 MCO Venting . . . . . . . . . . . . . . . . . . . . . . . . . . 32

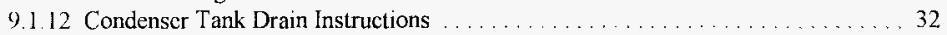

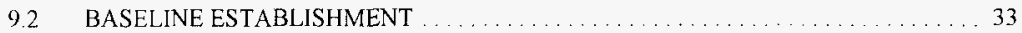

9.2.1 Prerequisitcs . . . . . . . . . . . . . . . . . . . . 33

9.2 .2 Vacuum Baseline Establishment Instructions . . . . . . . . . . . . . 33

9.2 .3 Helium Purge Baseline Establishment . . . . . . . . . . . . . . . . . . . 34

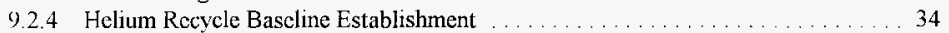

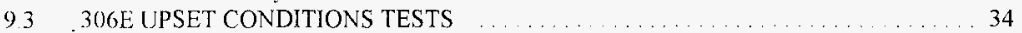

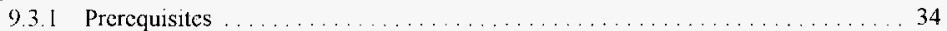

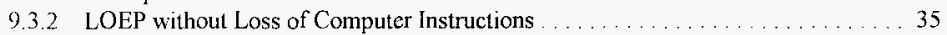

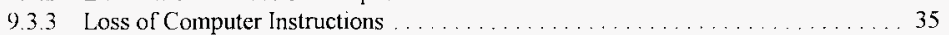


9.3.4 Loss of System Vacuum (Non-Vacuum Pump Failure) Instructions . . . . . . . 35

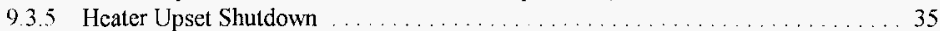

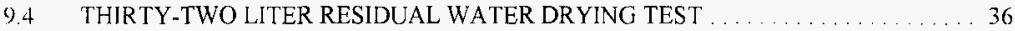

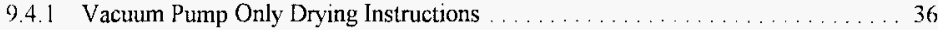

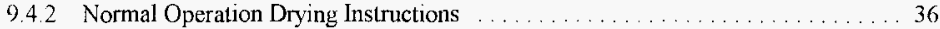

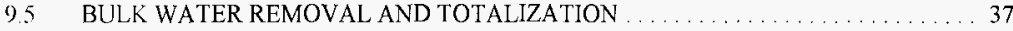

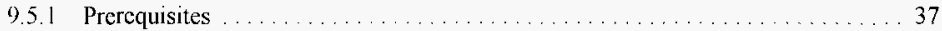

9.5.2 Bulk Water Removal with Clean and Empty MCO at Ambient Temperature . . . . 37

9.5 .3 Clean MCO with Basket and Mock Fucl (all configurations) . . . . . . . . . . 38

$96 \quad$ FUEL DRYING . . . . . . . . . . . . . . . . . . . . . . . . . . . 39

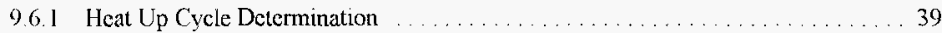

9.6.2 Pristine Fuel Normal Drying Scquence (Full 8-4-4 Cycle) . . . . . . . . . . . . . 40

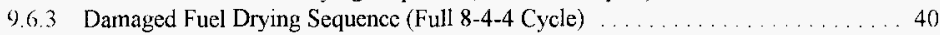

9.6.4 Mixed Fuel (Nominal) Normal Drying Sequence (Full 8-4-4 Cycle) . . . . . . . . 41

9.6 .5 Mixed Fuel (Nominal) Condenser/Purge 1 SCFM Cycle Drying . . . . . . . . . 42

9.6 .6 Mixed Fuel $\left(35^{\circ} \mathrm{C}\right.$ Bath) $8-4-4$ Cycle Drying . . . . . . . . . . . . . . 43

9.6 .7 Mixed Fuel Vacuum Only with Purge 1.6 SCFM Cycle Drying . . . . . . . . . . . 44

9.6 .8 Mixed Fucl $\left(10^{\circ} \mathrm{C}\right.$ Condenser $) 8-4-4$ Cycle Drying $\ldots \ldots \ldots \ldots \ldots \ldots \ldots 4$

9.6 .9 Mixed Fuel Helium Recycle or Purge Only Drying . . . . . . . . . . . . 45

9.6.10 Mixed Fuel (Nominal) Normal Drying Revised Sequence (Full 8-4-4 Cycle) . . . . 46

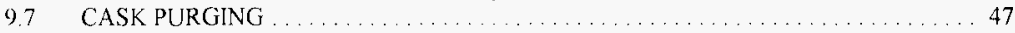

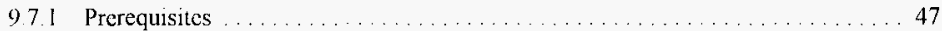

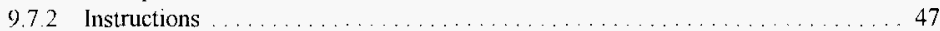

9.8 SPECIAL TOOLS AND SPECIAL FUNCTIONS $\ldots \ldots \ldots \ldots \ldots \ldots \ldots \ldots \ldots$

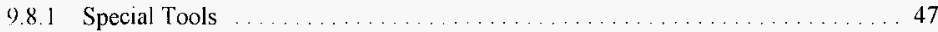

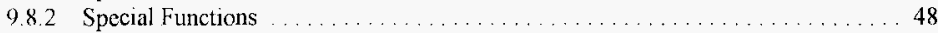

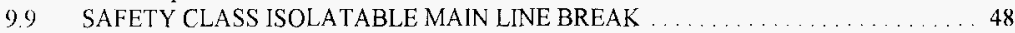

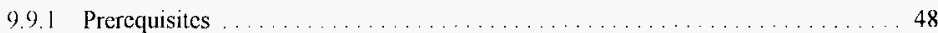

9.9.2 HEPA Filter Port Main Line Break Instructions $\ldots \ldots \ldots \ldots \ldots \ldots \ldots \ldots . \ldots . \ldots$

9.9.3 Diptube Port Main Line Break Instructions . . . . . . . . . . . . . . . . 49

9.10 SAFETY CLASS NON-ISOLATABLE MAIN LINE BREAK . . . . . . . . . . . . 49

9.10.1 Prerequisites . . . . . . . . . . . . . . . . . . . . . . . . . 49

9.10.2 HEPA Filter Port Main Line Break Instructions . . . . . . . . . . . . . 50

9.10 .3 Diptube Port Main Line Break Instructions . . . . . . . . . . . . . . . 50

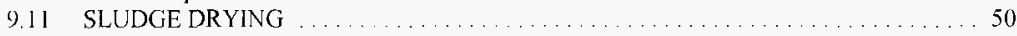

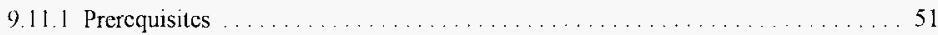

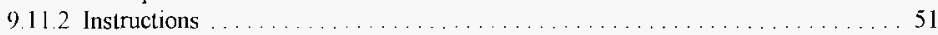

APPENDIX A TENTATIVE CVD PROOF OF PERFORMANCE TESTING SCHEDULE ... A A-1

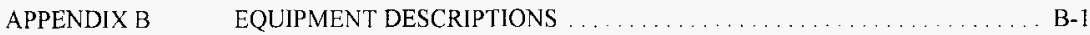

APPENDIX C TEST PROCEDURE EXCEPTION INSTRUCTIONS $\ldots \ldots \ldots \ldots \ldots \ldots$ C-1

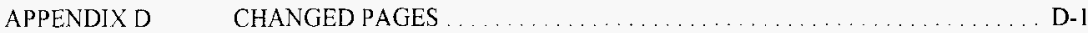

APPENDIX E WATER RETENTION TANK LEVEL DIFFERENTIAL AND VOLUME ... E-I

APPENDIX F INSTRUMENT CALIBRATION RECORDS $\ldots \ldots \ldots \ldots \ldots \ldots \ldots \ldots$

APPENDIX G PRE-JOB BRIEFING RECORDS $\ldots \ldots \ldots \ldots \ldots \ldots \ldots \ldots \ldots \ldots \ldots \ldots$ 
HNF-2402

Rev. 0

APPENDIX H SIGNATURE VERIFICATION DATA SHEET $\ldots \ldots \ldots \ldots \ldots \ldots \ldots \ldots$ H-1

APPENDIX I $\quad$ LEAK TEST PROCEDURES AND TEST REPORTS $\ldots \ldots \ldots \ldots \ldots \ldots \ldots$ I-1

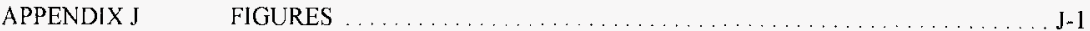




\section{LIST OF FIGURES}

Figure I. Water Retention Apparatus . . . . . . . . . . . . . . . . . . . . . . . . J-2

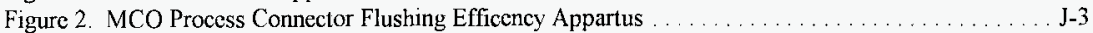

Figure 3. CVD Proof of Concept and Sludge Drying Apparatus Sketch $\ldots \ldots \ldots \ldots \ldots \ldots \ldots \ldots$ J-4

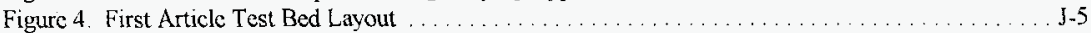

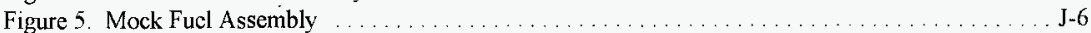

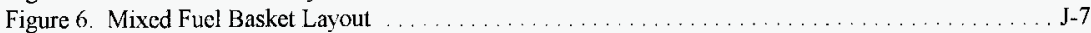

Figure 7. MCO Thermocouple Layout . . . . . . . . . . . . . . . . . . . . . . . J-8

Figure 8. Composite System P \& ID . . . . . . . . . . . . . . . . . . . . . . . J J

Figure 9. Remote PLC Layout for MCO, PWC, and SCHe Instrumtation . . . . . . . . . . . . J-10

Figure 10. SCHe GOV Power and Indication Wiring $\ldots \ldots \ldots \ldots \ldots \ldots \ldots \ldots \ldots \ldots \ldots \ldots \ldots$

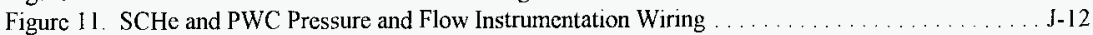

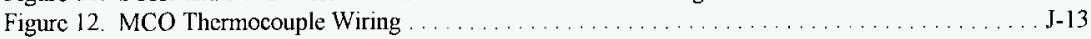

Figure 13. Process Hood, SCHe, and PWC Termination Panel Layout . . . . . . . . . . . . J-14

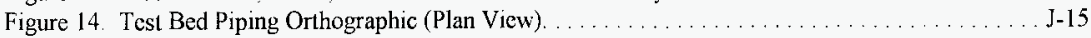

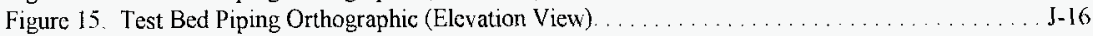




\subsection{INTRODUCTION}

\subsection{PURPOSE}

The objective of this document is to provide the test procedures for the Cold Vacuum Drying (CVD) Proof of Performance Cold Testing (First Article Testing) in support of the Cold Vacuum Drying subproject (CDVF). The CVD Facility and CVD process are described in detail in HNF-2356 Spent Nuclear Fuel Project Cold Vacuum Drying Facility Operations Manual. The test plan was based on the CVD design as evaluated at the $90 \%$ Design Review (January, 1998), although (to the extent possible) changes identified in the review are being incorporated during fabrication of test hardware. These proof of performance tests will be full scale and viewed as a continuation of the scale model proof of concept testing performed earlier (HNF-SD-SNF-TRP. 021 Hanford Spent Nuclear Fuel Cold Vacuum Drying Proof of Concept Test Report). The philosophy has been to procure a "first article" of each process system (skid) associated with the CVD facility. However, due to funding and schedule constraints, only the Vacuum Purge System (VPS) and the Tempered Water System (TWS) will be first article. The Process Water Conditioning (PWC) System, MCO/Cask Seal Ring, Local Process Ventilation Hood system, piping, MCO and cask will be full scale mockups or prototypes. The Safety Class I\&C System will not be tested, although a mockup of the Safety Class Helium Injection System will be included in performance testing. Some special tools required for the process such as the process connectors may also be classified as first article. Each system identified above will be tested together, as a whole, to validate process parameters, set points, and system response to normal and (limited) upset conditions in order to shorten the "in facility" pre-operational acceptance testing phase, and to provide information for the development of the CVD Process Simulator.

\subsection{SCOPE}

A testing strategy will be used to validate and verify that the VPS/TWS process equipment skid can perform its intended function as designed. The testing will also verify the performance capabilities of a prototype process ventilation hood/seal ring assembly, piping, a minimal first generation monitoring and control system (MCS), a portion of the PWC system, and a prototype safety class helium injection system. A transportation cask will be utilized with a prototypic MCO including simulated spent nuclear fuel clements. Testing will prove the capabilities of the process equipment as a unit.

Where tests indicate shortcomings, modifications to the process equipment will be integrated into the design as outlined in the VPS/TWS change control work plan (HNF-2548 First Article Process Equipment Skid Modification Work Plan). The equipment will be retested after the changes are made. Modifications will be incorporated via redlining to the "record" test drawings and documented in a future Design Modification Report. After preliminary testing, the redlined test drawings, the Design Modification Report on all process equipment and a future Operation's Maintenance Consideration Report will be forwarded to the Design Agent for formal changes to the process equipment specifications and drawings. Revised drawings and specifications will be forwarded to the appropriate vendor as a change order for evaluation and notice to proceed on the remaining process equipment. Additional details of configuration control are identified later in this document and the VPS/TWS skid change control work plan

Test articles consist of: process connector, MCO internal filter, basket offset or 'spider', four Mark IV fucl baskets and mock pristine and damaged fuel (up to 100\% mock damaged fuel elements with open ends and/or simulated cracks in four baskets to provide for maximum water retention in the MCO), a Mark IV scrap basket and mock scrap fuel (mock fuel pieces with damaged end caps, mock fuel pieces, 0.25 in. to 3 in), fincs (0.25 in. carbon stecl bcarings or fine gravel), and sludge simulant (as required). The test articles will be used to determine: 
- water retention amounts;

- heating cycle parameters (set points, ramp rates, and flow rates);

- bulk water removal and pipe cleansing parameters;

- $\quad$ sludge transport amounts from MCO to treatment system;

- drying duration and end point verification detection capabilitics;

- vacuum process and drying time establishment;

- helium recycle purge process establishment;

- combination vacuum and helium recycle process drying time establishment;

- final shipping test performance;

- $\quad$ cask purging performance;

- VPS skid operation, maintenance and leak checking processes or procedures;

- cquipment feature testing; and

- general service and safety class instrumentation, and control system performance

The feature testing will include performance of:

- $\quad$ process connector operation, sludge retention, and rinsing techniques;

- PWC ejector system;

- vacuum pump/condenser;

- helium circulation pump;

- $\quad$ system/piping and valves;

- cask, cask hood/seal ring and cask lower port connection assembly fit-up and operation;

- VPS Instrumentation and gas analysis system; and special tool operation.

\subsection{REFERENCES AND APPLICABLE DOCUMENTS}

DOE-RL-92-36, Hanford Site Hoisting and Rigging Mamual, Department of Energy, Richland, Washington 1997

HNF-PRO-078, Subcontractor Safety and Health Management, Rev 1, Fluor Daniel Hanford Company, Richland, Washington, Bell 1997.

HNF-PRO-079, Prejob Safety Planning, latest revision, Fluor Daniel Hanford Company., Richland, Washington, Bell, 1997.

HNF-PRO-081, Lock and Tag Requirements, Rev. 2, Fluor Danicl Hanford Company, Richland, Washington, Bell, 1997.

HNF-PRO-083, Personnel Protective Equipment Needs, Rev. 1, Fluor Daniel Hanford Company, Richland, Washington, Bell, 1997.

HNF-PRO-096, Material Handling and Storage, latest revision, Fluor Daniel Hanford Company, Richland, Washington, 1997

HNF-PRO-233, Review and Approval of Documents, Rev. 0, Fluor Daniel Hanford Company, Richland, Washington, 1997

HNF-PRO-242, Enginecring Drawing Requirements, Rev. 1, Fluor Danicl Hanford Company, Richland, Washington, 1997

HNF-N-62 Multi-Canister Overpack Component Tesing, Vol. 1, Fluor Daniel Northwest, Richland 
Washington, Ruff, 1997.

HNF-N-106, Cold Vacuum Drying Proof of Performance (First Article) Testing Log, Fluor Daniel Northwest, Richland Washington, McCracken, 1998.

HNF-2356, Rev. 0, Speni Nuclear Fuel Project Cold Vacuum Drying Facility Operations Manual, Duke Engineering Services Hanford, Irwin, 1998.

HNF-2548, Rev. 0, First Article Process Equipment SkidModification Work Plan, Numatec Hanford Corporation. Richland, Washington, Graves, 1998.

HNF-SD-SNF-OCD-001, Spent Nuclear Itiel Conditioning Product Criteria, Rev. 1, Hanford Corporation, Richland, Washington.

HNF-SD-SNF-TP-036, Rev. 0, Hanford Spent Nuclear Fuel Cold Vacuum Drying Proof of Performance Test Specification and Test Plan, Numatec Hanford Corporation, Richland, Washington, McCracken, 1997.

HNF-SD-SNF-TRP-(21, Rev. 0, Hanford Spent Nuclear Fuel Cold Vacuum Drying Proof of Concept Test Report, Numatec Hanford Company, Richland, Washington, Ritter, et al., 1997

RDC/DESH MCB-SLB-A06285-CAT-000, MCS Hardware Construction Acceptance Test, CH2MHill, Richland, Washington, DeSemple, 1998.

Report 627, Hammability Characteristics of Combustible Gases and Vapors, Bureau of Mines.

WHC-IP-0882, 306E Facility Administration Manual, Rev. 1, Westing House Hanford Company, Cronin, 1994.

W-441-PI Rev, N, Procurement Specification for the Fabricalion, Acceptance Testing, and Shipment of the Cold Vacuum Drying System Lquipment Process Equipment Skid, Numatec Hanford Compnay, Richland, Washington November, 1997

W-441-P2 Rev. N Procurement Specification for the Fabrication, Acceptance Tesing, and Shipment of the Cold Vacuum Drying Facility Process Water Conditioning Skid, Numatec Hanford Compnay, Richland, Washington November, 1997

W-441-P4 Rev. N Procurement Specification for the Fabrication, Acceptance Testing, and Shipment of the Cold Vacuum Irying Facility Process Hood, Seal Ring and Piping Assembly, Numatec Hanford Compnay, Richland, Washington November, 1997.

W-441-P5 Rev. N Procurement Specification for the Fabrication, Acceptance Testing, and Shipment of the Cold Vacuum Irying Facility Safety Class Helium System Equipment, Numatec Hanford Company, Richland, Washington November, 1997.

W-44I-P6 Rev. N Procurement Specification for the Fabrication, Acceptance Testing, and Shipment of the Cold Vacuum Drying Facility Safety Class Instrumentation and Control System, Numatec Hanford Company, Richland, Washington November, 1997.

H-1-83770, CVDF Process System Schematic, litrt Article Test, Numatec Hanford Company, Richland, Washington, Thomas, 1998 


\subsection{DEFINITIONS/ACRONYMN LIST}

BULK or FREE WATER

\section{CLEAN AND DRY}

CVD (Cold Vacuum Drying)

DRY

NORMAL SEQUENCE

(8-4-4 Cycle)

MCO (Multi-Canister Overpack)

MCS (Monitor and Control System)

MOCK FUEL

MCO Process Connectors

PWC (Process Water Conditioning)

RETAINED WATER

SCHe and SCIC
Water that is easily removed from the MCO or test apparatus by vacuum pumping or system purging with inert gas.

Visually clean and dry to the touch.

The process of removing water from the MCO and drying of the fuel

Dry is essentially less than a 3 torr pressure rise in the system over an hour period. Refer to Section 5.3.3 for acceptance criteria.

A "Full Cycle, 8-4-4 sequence" performed during a test is an 8 hour step with operation of the vacuum pump, condenser and helium purge (at $1.6 \mathrm{scfm}$ ), followed by a 4 hour helium purge at $1.6 \mathrm{scfm}$ or recycle (at $10 \mathrm{scfm}$ ), followed by 4 hours of vacuum pump operation. These durations may change throughout the course of testing.

The unit that will hold the fuel assemblies during the interim storage process. A full scale prototype will be used for the performance tests.

The MCS is the computer hardware and software including the programmable logic controllers to monitor and control the CVD process. A "first generation" system will be utilized for performance tests.

Unpainted carbon stcel tubing that simulates the $\mathrm{N}$ Reactor fuel, consisting of an inner and outer fuel element with approximately the same outside and inside diameter and wall thickness. The mock fuel will closely approximate the surface area of the real fuel. All the mock fuel elements will be allowed to rust throughout the testing and some elements will be initially damaged to provide water retention sites and debris as seen on the K Basin fuel and debris.

The process connectors are valve bodies that allow the MCO and VPS communication; these are to be prototypic for this testing.

The skid that contains the pumps, ejector, storage tanks, piping, valving, and instrumentation required to remove water from one full MCO. A mock-up will be used for performance testing.

Water remaining on articles after bulk water has been removed.

Safety Class Helium and Safety Class Instrumentation and Controls are defined as the stand alone system that is totally redundant and fail safe to prevent hydrogen burn and thermal runaway reactions inside the MCO in the CVDF facility. These systems will be a mock up for performance test applications. 
Seal Ring/Process Ventilation Hood

\section{SLUDGE SIMULANT}

TEST LOGBOOK

TEST PROCEDURE

TWS (Tempered Water Systcm)

VPS (Vacuum Purge Systcm)
The seal ring is the apparatus that is bolted to the cask top to create a scal between the cask and the MCO to maintain the tempered water closed loop system. The seal is accomplished by an inflatable O-Ring. The process ventilation hood attaches to the seal ring and provides air flow for removing airborne contaminants (in the CVDF) at the top of the $\mathrm{MCO}$. The hood is also used to house the process connectors. The seal ring/process ventilation hood assembly will be a prototype rather than fabricated as a "first article" for these performance tests.

The simulation of $\mathrm{K}$ Basin fuel sludge. The CVD project with information from SNF characterization will provide approximate sludge simulant ingredients and application techniques.

A logbook for recording all data and observations by the test performer which are not included in a test procedure

A test procedure determines the steps for each test and provides documentation for process parameters that will be established during the testing.

Considered part of the VPS skid, the TWS contains the pumps, heaters, piping, valving, and instrumentation designed to heat the $\mathrm{MCO}$ inside the transporter cask to $85^{\circ} \mathrm{C}$, or cool it to $10^{\circ} \mathrm{C}$. During normal operations, the TWS will operate between $25^{\circ} \mathrm{C}$ and $50^{\circ} \mathrm{C}$.

The skid that contains the vacuum pump, helium circulation unit, heat cxchangers, piping, valving, and instrumentation required for the vacuum drying process. This skid will be "first article" for performance testing.

$\begin{array}{ll}\text { CVDF } & \text { Cold Vacuum Drying Facility } \\ \text { CM } & \text { Control Manual } \\ \text { CSB } & \text { Canister Storage Building } \\ \text { DAS } & \text { Data Acquisition System } \\ \text { DOE } & \text { Department of Energy } \\ \text { ECN } & \text { Engincering Change Notice } \\ \text { EDL } & \text { Engincering Development Laboratory } \\ \text { GOV } & \text { Gas Operated Valve } \\ \text { HNF } & \text { Hanford } \\ \text { HRS } & \text { Helium Recirculation Systcm } \\ \text { I\&C } & \text { Instrumentation and Control } \\ \text { JHA } & \text { Job Hazard Analysis } \\ \text { MCO } & \text { Multi Canister Overpack } \\ \text { M\&TE } & \text { Measurement and Test Equipment } \\ \text { MSDS } & \text { Material Safety Data Sheet } \\ \text { NDE } & \text { Non Destructive Examination } \\ \text { PWC } & \text { Process Water Conditioning } \\ \text { QA/QC } & \text { Quality Assurance/Quality Control } \\ \text { RGA } & \text { Residual Gas Analyzer } \\ \text { SCHe } & \text { Safety Class Helium } \\ \text { SCIC } & \text { Safety Class Instrumentation and Control } \\ \text { SNF } & \text { Spent Nuclear Fucl } \\ \text { TWS } & \text { Tempered Water System } \\ & \end{array}$


VPS Vacuum Purge System

WRT Watcr Retention Tank

\subsection{SAFETY}

\subsection{GENERAL SAFETY CONSIDERATIONS}

All work completed shall be performed in accordance with the appropriate Project Hanford Occupational Safety and Health Policies and Procedures.

A pre-job mecting will be required before testing begins (per HNF-PRO-(079) to discuss personncl protective equipment needs (HNF-PRO-083), lock and tag requirements (HNF-PRO-081), subcontractor Safety and Health Management (HNF-PRO-078), and other relevant issues.

Salety review analyses or a Hanford Job Hazard Analysis (JHA) checklist and a 306E Specific JHA checklist shall be prepared and approved prior to testing in accordance with appropriatc Hanford procedures.

Therc is no radiation work associated with the test activities described in this test procedure.

Oniy the test director, cognizant test engineer, and/or their approved test personnel shall operate the test cquipment.

The following scctions specify safety requirements and precautions applicable to this testing.

\subsection{PERSONNEL PRECAUTIONS}

\subsubsection{Injury Notification}

The $306 \mathrm{E}$ building administrator shall be immediately notified if any personnel injury occurs. If the injury also warrants the need for outside assistance, medical aid shall be obtained by phoning 911 .

\subsubsection{Job Hazard Analysis}

A JHA checklist shall be prepared in accordance with HNF-PRO-079, Pre-Job Safely Planning, prior to testing and approved by the industrial safety representative and $306 \mathrm{E}$ facility management. All personnel pcrforming this test procedure and related work shall read and sign the JHA for this job. The onshift test engineer shall be responsible for ensuring this requirement is met.

\subsubsection{Lock and Tag}

Lock and tag shall be conducted in accordance with HNF-PRO-081, Hazardous Energy Control Program, and zero energy checks, mechanical or electrical, shall be performed on the affected system.

\subsubsection{Lifting}

All manual lifting shall be performed in accordance with HNF-PRO-096, Material Handling and 
Storage, and all mechanical lifts shall be performed in accordance with DOE-RL-92-36, Hanford Site Hoisting and Rigging Manual.

\subsubsection{Test Equipment Operation}

Only the test director, test enginecrs, and test director approved test performers shall operate the CVD test equipment.

\subsection{EQUIPMENT PRECAUTIONS}

\subsubsection{Energizing Equipment}

Supply power to a component must be off when connecting or disconnecting any electrical cables to that component. Where applicable supply power sources shall be locked and tagged in accordance with 4.2.3 to prevent the unexpected release of hazardous electrical energy.

\subsubsection{Equipment Operating Manuals}

The operating manuals for the VPS skid equipment, heaters, vacuum pumps, etc., shall be read, understood (by the test performers and engineers) and documented on the prejob briefing forms located in Appendix $G$ prior to testing to prevent equipment damage. Personnel safety and equipment precautions specified in the operating manuals shall be complied with throughout testing.

\subsection{ORGANIZATION RESPONSIBILITIES, AUTHORITY, AND ADMINISTRATION}

The Hanford Spent Nuclear Fuel (SNF) Project organization has ultimate responsibility for the CVD performance tests. Specific testing responsibilities are defined in the following sections.

\subsection{ORGANIZATION RESPONSIBILITIES}

\subsubsection{SNF and SNF CVD Project}

The Hanford Spent Nuclear Fucl (SNF) CVD project shall provide the Design Authority, Test Director, Technical Engineer and Quality Assurance Personnel as required for the CVD proof of performance testing.

The Hanford Spent Nuclear Fucl Project shall supply a prototypical mechanical closure MCO with shield plug, locking ring, and intcrnal HEPA filter; four Mark IV fucl basket prototypes and one Mark IV scrap basket prototypc; specifications for mock N Reactor Mark IV pristene and damaged fuel assemblics and mock scrap fuel. In addition, the chemical composition, preparation specifications and application procedure for simulated sludge were provided. The CVD project will supply the VPS/TWS skids, the Process Seal Ring Assembly mockup and the process connectors, plus a chiller required for the VPS chilled water system (minimum 10,000 Btuh at $0^{\circ} \mathrm{C}$ ). The CVD project also supplied the MCS system and design specifications for an equivalent PWC, safety class helium purge, and instrumentation systems ( $\mathrm{SCHc}$ and SCIC). 


\subsubsection{Engineering Development Laboratory (EDL)}

The proof of concept test stand, test mock-up apparatus (except VPS/TWS), and test articles are to be fabricated by the $306 \mathrm{E}$ Building EDL personnel. Test laboratory personnel shall prepare mock fuel, sludge simulant, and scrap fucl, to conduct retained water location tests, and to assist in first article testing as required. EDL shall modify (as necessary) mock fuel assemblies using commercially available stecl. EDL also shall construct the piping interfaces to mechanically connect the skids with design specified piping diameters and equivalent lengths to provide power for all components and skids. EDL shall fabricate the equivalent SCHe prototype, PWC mockup and process ventilation hood and piping assembly from commercially available general service components.

\subsubsection{Engineering Analysis}

Support from Engineering Analysis, currently John Marvin Inc. and FDNW SNF Engineering assists, as needed, in the test requirements and to perform compilation of testing results and test report preparation.

\subsubsection{Quality Assurance}

SNF Project Quality Assurance (QA) shall provide review of the test procedure(s) and will review the test report. SNF Project Quality Control (QC) shall provide support for the dimensional measurement of test components and independent verification of test apparatus set-ups and shall provide independent verification of selected hold and/or witncss points in the test procedure. SNF project QC shall provide certified personnel to support measurements or verification activities required by the test procedure.

\subsection{ALTTHORITY}

\subsubsection{Project Design Management and Design Authority}

The CVD project management includes project management and design authorities. The design authority has final authority over the conduction, repetition, or cancellation of any or all CVD tests. The CVD management and design authority directs the test director and may consult the technical engineer and test director for test input. The project management has the responsibility to communicate any changes to the "First Article" testing that may impact other SNF organizations such as operations and start-up.

\subsubsection{Test Director}

The first article lesting test director is responsible for the overall performance of the test procedurc and personncl safety. The test director shall be qualified by familiarity with the project, systems functions, and equipment operation. The test director is also responsible for all test material and personnel resource coordination. The test director directs the test engineer and reports to the design authority and project management. The test director may also be a test engineer and a test performer. The test director can act as both the test director and test engineer. The test director shall be appointed by the CVD project management and is currently assigned from FDNW. In the event of test director absence, the test director or project management may assign the responsibilities to another qualified individual. 


\subsubsection{Technical Engineer}

The technical engineer, currently from John Marvin Inc., will provide test design information and test data reduction as required during the course of these tests. The technical engineer may request a repeat test with concurrence from the design authority and test director.

\subsubsection{EDL Manager}

The EDL manager is responsible to coordinate all activities in the $306 \mathrm{E}$ facility and provides an interface with building management and personnel to establish prioritics and requirements. The EDL manager shall assure the test set-up, conduction, and safety precautions are within the facility guidelines outlined in WHC-IP-0882 306E Facility Administration Manual.

\subsubsection{Test Engineer}

The test engincer is responsible for directing performance of the test procedure and for personnel and plant safety as related to the performance of the test procedure. The test engineer directs personnel assigned to the test procedure. The test engineer reports to and is designated by the test director. The test engineer may be the test director and a test performer.

\subsubsection{Test Performers/Operators}

The test performers are directed by the test engineer. The test performers are directly responsible for test procedure performance, personnel safety, and cquipment precautions designated in the cquipment operation manuals. The test performers report to the test engineer and test director. The test performers are designated by the test director.

\subsubsection{Test Review Board}

The test review board shall provide a review of the test procedure(s), design modification report, and final test report(s). All redline changes to the first article skids, that are under configuration control, are subject to review by the appropriate members of the test review board as defined in the skid modification work plan. The test review board consists of: project management, design authority, test director, quality assurance, safety, design agent, test facility management, technical engineer, and DOE for informational purposes.

\subsection{ADMINISTRATION}

\subsubsection{Tagouts}

Tagouts shall be conducted in accordance with the appropriate Project Hanford Occupational Safety and Health Policies and procedures; and in accordance with the WHC-IP-0882 306E Facility Administration Manual as applicable. Zero energy checks (mechanical or electrical) shall be performed on the affected system. All tagouts shall be applied in accordance with section 4.2.3. 
HNF-2402

Rev. 0

\subsubsection{Test Changes}

Test procedure changes required during testing as described in HNF-SD-SNF-TP-036, cxcluding the skid drawings, sketches, or specifications (see section 5.3.10 below and as described in the skid modification work plan), may be made immediately in the field copy test procedure change sheets, provided that the changes cannot affect operating test facility safety, function, or performance and will not compromise or influence test data. Any such change must be recorded in the change log as a change exception and in the test $\log$. Test parameters may be changed with concurrences of the appropriate members the test review board (see section 5.2.7). At a minimum, the design authority, test director, EDL manager, and the technical engineer, shall concur with all test changes. Changes to quality assurance functions (e.g., QA/QC verifications, inspections, documentation) requires concurrence of the SNF Project Quality Engineer. All procedure changes shall be incorporated (at the end of testing) with an ECN.

Test changes that affect operating facility safety, function, or performance, or will compromise or influence test data are made via engineering change notice (ECN) to the test procedurc; the ECN will be approved by (at a minimum) the design authority, test director, facility manager (for facility safety), EDL manager, the technical engineer and the appropriate members of the Test Review Board.

Tests outlined in this plan may be performed out-of-sequence, if deemed appropriate by the test director with concurrence of the EDL manager, and the change documented in the test log.

\subsubsection{Acceptance Criteria}

The tests outlined in this document are expected to validate and/or establish a "recipe" for operation of the CVD process. The design input parameters shall be entered to the process control system and obscrvations shall be made to determine minimum heat-up cycles and maximum water removal rates. For any step in the test procedurc that has an associated acceptance criteria, the value will be designated in that step. The governing acceptance critcria, based on commercial practices, is an internal vacuum chamber pressurc rebound of less than 3 torr within $1 \mathrm{hr}$. If the pressure rebounds above this limit, the drying specimens (mock fucl, sludge, or scrap fuel) arc not completely dry. The pressure rebound starts after the vacuum vessel is pumped down to a base pressure, tentatively 0.5 torr, and the vacuum pump is isolated.

\subsubsection{Test Validity}

A specific test is valid if equipment, instrumentation, and data acquisition systems function satisfactorily during the test (i.e. vacuum pump maintains required system vacuum over the test duration, temperature detectors provide accurate readings, pressure gauges maintain accurate pressure indication, computer maintains data acquisition of these parametcrs and other control functions, etc.). Hardware failures must be recorded in an exception log, in a test log, and on an exception page. The test engineer will decide whether to continue with the test procedure in the event of a test step or equipment failure. The validity of a test in which hardware failures occur and the need to repeat it will be determined by the test director and Test Revicw Board.

\subsubsection{Test Log}

A narrative log of testing activities is to be maintained by the test engincer. Page numbers and dates shall be entered as new pages are added. Each added page will be stamped "CONTROL COPY". Dark, reproducible ink shall be used for all entries. The test $\log$ is in HNF-N-106, Cold Vacuum Drying Proof of Performance (First Article) Tesing Log. 
HNF-2402

Rev. 0

\subsubsection{Exceptions}

The test procedure shall not be closed with open exceptions. All exceptions shall be recorded per the test procedure exception instructions located in Appendix $\mathrm{C}$ unless it is immediately correctable and retested. Prior to the close of the test procedure, each exception is dispositioned. When all exceptions are dispositioned then the test procedure may be closed. The test procedure does not have to be changed due to the existence of an exception, however a change may be warranted if the exception causcs a significant impact to the performance of the test procedure

\subsubsection{Exception Dispositioning and Closing}

Dispositioning of exceptions can be accomplished in one of two ways, clear the exception or change the requirement/procedure (refer to Section 5.3.2 and 5.3.6). Exceptions are then closed when they have been dispositioned and signed by the test director.

\subsubsection{Signatures}

All personncl entcring signatures or initials in the test procedure must print their name and provide their signature and initials in the test procedure signature identification log located in Appendix $\mathrm{H}$.

\subsubsection{Repeat Testing}

One intent of first article testing is to verify computer models; if verification is accomplished, then repeat testing will not be required during performance testing. However, if invalid results are obtained because of equipment failure, or unexpected results are obtained, a particular test(s) will be repeated.

If repeat tests are required because of configuration or design changes, additional copies of applicable procedure sections or test procedure data sheets may be used. The addition of procedure sections to be used for repeat testing shall be added as Repeat Testing, noted in Appendix K, and concurred with by the test director and EDL manager.

\subsubsection{Test Configuration Control}

Changes required to the test procedure, shall be controlled per section 5.3.2. Changes to facility use hardware shall be controlled by HNF-2548, Hanford Spent Nuclear Fuel Cold Vacuum Drying Process Equipment Sikid Modification Work Plan.

Identıfied facility use hardware drawings, sketches, and specifications included as attachments within the test procedure shall be identified "Development Control". Changes, additions, or deletions to the "Development Control" drawing, sketch or specification shall be controlled by either marking the change in "red" or preparing additional pages or sketches and identifying traceability with the affected drawing, sketch, or specification. All changes shall be signed and dated next to each change by the design authority (for design baseline documents) or cognizant engineer (for all others) and also noted in the test log. The "Development Control" process specified within the test plan and procedure shall be applied to required changes during this phase of development, fabrication, and testing. Drawings, sketches, or specification originals under "Development Control" shall not be revised by ECN. At the end of development and fabrication. all "Development Control" changes shall be incorporated into the appropriate engineering 
documents. Engineering drawings shall be prepared and relcased as $\mathrm{H}$-series or "SK" drawings in accordance with HNF-PRO-242 (formerly HNF-CM-6-I EP-1.3).

\subsection{GENERAL INSTRUCTIONS}

This section provides general requirements that apply during the entire test procedure performance. All Test Engineers and Test Performers must read this section prior to performing any test procedure testing.

\subsection{INSTRUCTIONS}

\subsubsection{Exceptions}

An exception shall be logged for any step not meeting the requirements of the test procedure. An exception number must be obtained and a short description entered in the exception log in the Appendix C.

\subsubsection{Test Performances}

Each section is performed sequentially. Each test shall be performed at a minimum of two (2) times for data repeatability unless otherwise noted by the test director. The Test Engineer has authority to perform major sections out of sequence (without a test procedure change) provided:

1. The "Prerequisites" in that section are completed.

2. Performing the section out of sequence will not adversely impact any unfinished (previous or subsequent) sections or adversely impact the test procedure performance schedule.

3. The section does not bypass basic equipment control and interlock tests (related to the section) performed in previous sections

4. Concurrence from the Technical Engineer and Test Director are obtained and entered into the Test Log.

5. NO HOLD POINTS (Hold Point or HP) shall be by-passed.

6. When using computer manual sequencing (scction 9.1), the valves that are referenced are to bc actuated in the order in which they are listed. Any changes to this order, a test exception or red line change shall be required and noted in the tesing log.

\subsubsection{Signoffs}

The Test Engineer sign off of test steps certify that direct observation or inspection has been made or that a report was received from tost personnel signifying that the step was performed.

\subsubsection{Pre-job Briefing}

Prior to the start of any work performed under this test procedure, a pre-job bricfing will be conducted. The mecting shall be chaired by the test director. For each pre-job briefing, a form will be filled 
out and placed in Appendix G. At a minimum, the following topics will be discussed at the meeting:

a. Expected testing to occur on shift

b. Spccial safety concerns, including lifting precautions and electrical safety;

c. General facility and test procedure status; and

d. Review of the JHA.

\subsubsection{Test Log}

A test logbook will be maintained by the Test Enginecr. The Test Engineer shall be the designated logbook custodian. All pertinent observations, off-normal events, sketches, photographs, etc., shall be logged. All logged entrics shall be signed and dated in dark, reproducible ink. Additional notes or entries relating to a procedure data shect entry field or information shall be adequately referenced to the appropriate section of this procedure. The test log is HNF-N-106

\subsubsection{Measurement accuracy}

Dimensional measurements shall be taken to the nearest millimeter. Temperature measurements shall be taken to the nearest $2^{\circ} \mathrm{C}$ and time measurements will be to the nearest second. Pressure measurements shall be taken to the nearest 0.5 psig, psia and 0.1 torr. Calibration records shall be retained in Appendix F.

\subsection{PREREQUISITES}

The following sections specify prerequisites that must be completed prior to the start of the entire test procedure. In addition, some sections of the test procedure have special prerequisites that must be completed prior to starting that particular section only.

\subsection{INSTRUMENTATION CALIBRATION}

The test engineer and QA/QC representative shall verify that test instrumentation, items 81 through 91 in Appendix F, are within their current calibration cycle. Place all calibration records in Appendix F and sign below to confirm that test instrumentation are HSL calibrated, field verified, or have manufacturer calibration sheets.

Hold Point

\begin{tabular}{ll}
\hline Test Engineer & Date \\
\hline QA/QC & Date
\end{tabular}

\subsection{ADDITIONAL INSTRUMENTATION CALIBRATIONS}

Instrumentation residing on the VPS/TWS skid, items 1 through 79 in Appendix F, shall be calibrated by the Hanford Standards Lab (HSL), ficld verificd by using calibrated M\&TE and logged, or have the 
manufacturer calibrations sheets as prescribed in Appendix $F$. Record all information on the field verification data sheets located in Appendix F. At a minimum, M\&TE calibration number, last and next calibration date, as found and as left five point data across the instrument range, and any comments on instrument calibration adjustments.

Hold Point

\begin{tabular}{lc} 
& \multicolumn{1}{c}{ Date } \\
\hline Test Engineer & $/$ \\
\hline QC & Date
\end{tabular}

\subsection{NDE LEAK TEST}

A helium leak test shall be performed by qualified NDE personncl on all VPS process lines prior to tcsting. Also, a helium leak test shall be performed on the assembled $\mathrm{MCO}$. The leak ratc of the process systcm, which includes the VPS, HRS, and MCO, shall be less than $1 \times 10^{-5} \mathrm{std} . \mathrm{cm}^{3} / \mathrm{s} \mathrm{He}$. If there is excess leakage in the systcm, perform diagnostics, and contact test engineer and EDL staff to assist in system repair. After repairs are completc, recheck leak ratc.

Record equipment calibration information in Appendix F. Sign below to indicate initial system lcak tests have becn satisfactorily completed.

\section{Hold Point}

\begin{tabular}{lc} 
& \multicolumn{1}{c}{ Date } \\
\hline Test Engineer & Date
\end{tabular}

\subsection{PRE-JOB SAFETY BRIEFING}

Prior to the start of any work performed under this test procedure, a pre-job safety briefing shall be conducted. Additional pre-job briefings will be performed throughout testing as required by the test director. The briefing shall be chaired by the test director or test designee. For cach pre-job briefing, a form provided shall be completed and placed in Appendix G. At a minimum, the following topics will be discussed:

- Expected testing to occur on shift

- Special safety concerns, including lifting precautions and electrical safety

- General facility and test procedure status

- Review of applicable MSDS's

- Review of the JHA

Place all pre-job briefing forms in Appendix G

\subsection{TEST APPARATUS SET-UPS AND PRE-TEST PERFORMANCES}

\subsection{APPARATUS SET-UPS INSTRUCTIONS}

This section provides input required to set-up and fabricate the first article test bed and miscellancous 
test stands such as the mock fuel fabrication, the first article test bed, the water retention and totalization test stand, and the valve flushing test stand

Photographs shall be taken of each test apparatus and test article(s) and placed in the test log.

\subsubsection{Prerequisites}

These set-ups and verifications may be performed concurrently or out-of-sequence depending on test schedule, equipment deliveries, and/or test directors discretion, however NO HOLD POINTS (HP) shall be by-passed.

\subsubsection{Mock Fuel Fabrication}

Assure the mock fuel test articles are fabricated in accordance with the test director and QC inspect $10 \%$ of the mock fucl test articles in reference drawing SK-2-300395. Refer to Appendix J Figure 5 for general fabrication assistance.

Simulated course scrap fuel shall be fabricated by cutting mock fuel elements (inners and outers) into random lengths ranging from $1 / 4 \mathrm{in}$. to $3 \mathrm{in}$. long. Simulated fine scrap fuel shall be fabricated by breaking cast iron pipc, 1 to 3 inches in diameter, into small pieces ranging from $1 / 4$ in. 101 in. shards. Note inventory simulated scrap fuel in test log book.

Hold Point

$\frac{\text { Test Engineer }}{\mathrm{QC}} \frac{}{\text { Date }}$

\subsubsection{Equipment Performance Testing Apparatus (First Article Test Bed)}

Assure the test apparatus is fabricated in accordance with the test plan and the test director. Instrumentation calibration records are supplied and located in Appendix F. Changes to the test fixtures that differ from the $90 \%$ shall be documented in the Test Log Book HNF-N-106. (Refer to Figure 2, 8, 9, 10, 11, $12,13,14$, and 15 in Appendix $J$ for general set-up assistance.) Figure 8, (H-1-83770) the CVD process system composite P \& ID shall be avavilable on a full size drawing sheet maintained under the development configuration control at the test facility

Apparatus List

Hood Process Piping Assembly

PWC \& Connection Piping

Ventilation Hood and Seal Ring

Cask

Water Retention Apparatus

Electrical Power Distribution
VPS Chilled Water

TWS Chilled Water

Helium Supply

Compressed/Instruments Air Supply

Water Supply

PWC Water Heating System

$\frac{1}{\text { Test Engineer }}$




\subsubsection{Water Retention Apparatus}

Assure the test apparatus is fabricated in accordance with the test plan, the test director and calibration records for the measuring and test equipment requiring calibration are current and copies in the log book. Exceptions to the 90\% design packages shall be documented in the Test Log Book HNF-N- 106 . Refer to Figure l (Appendix J) for general set-up assistance.

$\frac{}{\text { Test Engincer }}-\frac{}{\text { Date }}$

\subsubsection{Valve Flushing/MCO Water Ingress Test Stand}

Assemble/fabricate test apparatus per test enginecr's direction using Figure 4 (Appendix J) as a guide. Assuring the isolation valve is in the vertical orientation and proper installation of the instrumentation.

$\frac{1}{\text { Test Engineer }}$

\subsection{PRE-TEST PARAMETER ESTABLISHMENT}

This section provides first article pre-testing to establish parmaters for mock fuel and basket water retention, bulk water removal and totalization, process connector flushing and $\mathrm{MCO}$ water ingress testing, ventialation hood airflow testing, seal ring leak testing, and MCS set-up, control, and data logging testing.

\subsubsection{Fuel Basket/Fuel Water Retention Test}

This scries of tests examines the amount and location of water retained on a prototypic, single MCO fucl basket, mock fucl in a varicty of conditions ranging from pristine to fully damaged with simulated scrap. The tcst apparatus is described in section 8.2 .3 and Figure 1 (Appendix J). The pristine and damaged fuel water retention tests were performed during the proof of concept testing and documented in Ritter, et al (1997). The tests will be conducted with the basket of mixed mock fuel as shown in Figure 6 (Appendix J); then the test will be repeated adding scrap fucl with and without fines. When each test article is removed from the water, a close video camera inspection with editorial comments will indicate where the remaining water is located. The test article shall be monitored during the drain time, up to 30 minutes after removal from water. Averaging techniques will be employed for these tests due to the uncertainty involved in qualifying and quantifying retained water. Equipment required for $\mathrm{MCO}$ water retention tests is

water retention measuring device; prototypic MCO fucl basket:

mock N Reactor fucl (pristine and damaged);

simulated scrap; and

prototypic MCO scrap basket with fines compartment.

\subsubsection{Prerequisites}

1.0 START video recording prior to cach test.

2.0 RECORD data in test log book. 
HNF-2402

Rev. 0

\subsubsection{Water Retention Testing Instructions}

1.0 FILL the WRT with approximately $61 \mathrm{~cm}$ (24 in.) of water (enough water to completely submerge the prototype fuel basket). ALLOW the water to settle (1-5 min) and RECORD the initial water level using the vernier scale and hook gauge or other apparatus.

2.0 SUBMERGE the fuel basket in the WRT. ALLOW basket to soak for 5-10 minutes. ELEVATE basket above the water surface and ALLOW dripping to start. Within 2 minutes RECORD the first watcr level indication. ALLOW water to drip for 30 minutes into the WRT. RECORD at a 15 minute interval and the final WRT level.

3.0 DETERMINE the amount of water left on the basket (initial and final) by using the level differential volume equivalent graph in Appendix E

4.0 PLACE basket in an air stream for approximately 2 hours or until basket is visually dry and dry to the touch. REPEAT steps 1.0 through 3.0 one additional time for the same basket. ALSO REPEAT TWO (2) times for basket and fuel assembly configurations (pristine, damaged, mixed); sludge; basket, fuel, and sludge; scrap basket; and scrap basket and scrap. FILL out water retention table in test log book. (Note: Due to some of the difficulties that may be encountered measure sludge and debris water retention, these tests may be NA until a later date or disregarded. The decisions shall be noted in the test log with concurrences from the test director, technical engineer, and design authority.)

Appendix E complete

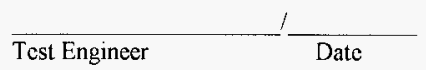

\subsubsection{Bulk Water Removal and Totalization (MCO Only)}

\subsubsection{Prerequisites}

1.0 Fill MCO with approximately 150 gallons of watcr using a technique described in section 9.1.10

\subsubsection{Clean, Dry, and Empty MCO Instructions}

1.0 Evaluate the MCO Bulk Water using section 9.1.1.

\subsubsection{Process Connector Flushing, System Flushing Efficiency, and MCO Water Ingress Test}

An apparatus, conceptually shown in Figurc 4 (Appendix J), shall be fabricated to test the VPS deionized water flush after the bulk water draining proccss. The apparatus consists of a process connector and shield plug valve assembly prototype and a gas operated ball valve (GOV) down stream of the process connector. This GOV will utilize the same seats and scals as specified in the $90 \%$ Cold Vacuum Drying System Equipment Process Equipment Skid, W-441-P1 Revision N procurement specification for GOV 1230 and GOV 1203. The purpose of this test is three fold: to identify any sludge traps in the process connector, to optimize flow settings providing maximum sludge clean-out without introducing added water back into the $\mathrm{MCO}$, and to test the sealing and isolation capabilities of the valve after the introduction of sludge.

These tests will determine if sludge will remain in the process connector, piping, and valves after 
rinsing. If so, significant connector redesign and valve seat specification may be necessary to reduce any radioactive dose an employee may receive while handling the connector. The process connector sludge retention test is conducted using a process connector and flowing a Magnaflux/sludge simulant/water solution through the connector and test body. The process connector will be removed from the test body and visually inspected with ultra-violet light to qualitatively determine the amount of sludge simulant on the process connect. The proccss connector will then be replaced on the test body and a flushing routine will be initiated. Once again, the process connector will be removed from the test body and visually inspected with UV light to determine the amount of sludge simulant remaining in the connector. If the connector shows signs of buildup , the process connector should be redesigned and retested to minimize sludge build-up. The process connector will also be leak checked after 20 donning/doffing and actuating sequences to check for any $\mathrm{O}$-ring and seal leakage.

The MCO drain process is controlled primarily by the VPS 1230 valve for isolation. This valve has the potential for seat and seal scarring from the MCO sludge being trapped prior to rinsing. The component must remain suitable for its intended use. A sludge simulant/water mixture shall be flowed through the valve and rinsed. This process may be repeated any number of times and valve leak tightness re-verified.

\subsubsection{Prerequisites}

1.0 Test stand has been fabricated per section 8.1 .5

2.0 MIX sludge per test engineer's direction using water, Kaolin, and/or Minusil with a Magnaflux as a tracer additive. Note Mixture "recipe" in logbook

Sludge Preparation

$\frac{1}{\text { Test Engineer }}$

3.0 RECORD all data in the test log book.

4.0 NDE leak check process connector to be leak tight to $1.0 \times 10^{-6} \mathrm{std} \mathrm{cc} / \mathrm{sec} \mathrm{He}$.

\begin{tabular}{ll} 
Test Engineer & Date \\
& 1 \\
\hline NDE & Date
\end{tabular}

\subsubsection{Apparatus Set-up and MCO Water Ingress}

\subsection{Acceptance Criteria}

Air flow and/or water flow DOES NOT enter the drop out tank for a period of 30 minutes.

\subsection{Instructions}

1. 0 ATTACH the process connector with bottom O-Ring in place to the mounting apparatus. TORQUE the process connector to $40 \mathrm{ft}$. lbs. using a criss-cross pattern in asending torque stages and a final check around the bolts. (Note: use unlubed condition, per HNF-N-62 Multi-Canister Overpack 
Component Testing, Vol 1, Ruff, 1997).

2.0 OPEN process valve to internal process connector stop.

3.0 SET and ADJUST as necessary, the air pressure to $20 \mathrm{psig}$ and flow to $5 \mathbf{s c f m}$. START the ejector flow pump and ALLOW flow to stabilize. RECORD ejector inlet flow and pressure readings. SET and ADJUST as necessary, the DI water pressure to $20 \mathrm{psig}$ and flow to $5 \mathrm{gpm}$.

4.0 FLUSH process connector for 5 minutes and OBSERVE and RECORD any water drop out in the drop out tank on the botiom of the mounting apparatus. IF ANY water is observed, INCREASE AND/OR DECREASE the air flow and/or water flow until water DOES NOT enter the drop out tank for a period of $\mathbf{3 0}$ minutes. RECORD the final pressure and flow settings in the data table.

5.0 ISOLATE DI water and air sources THEN STOP the ejector flow pump, and THEN close the isolation valve to the ejector. NOTE: This sequence must be followed to assure the system stays as dry as possible

\subsubsection{Process Connector Flushing Efficiency Test}

1.0 REMOVE process connector from apparatus. RECORD the process connector TARE weight ( \pm 1 gram). APPLY an even coating of sludge mixture approximately $1 / 16 \mathrm{in}$. $(1.6 \mathrm{~mm})$ thick to the process connector cavity. CAUTION: DO NOT apply sludge to the O-Ring seal on the process connector bottom. IF the O-ring becomes contaminated with sludge--REMOVE using a damp cloth. VIDEO TAPE the sludge layer under an ultraviolet lamp to verify the Magna-flux tracers.

2.0 REMOVE the process valve simulator from the mounting apparatus. RECORD the process valve TARE weight ( \pm 1 gram). APPLY an even coating of sludge mixture approximately $1 / 16$ in. $(1.6 \mathrm{~mm})$ thick to the process valve cavity and top interface scaling surface. IF the threads become contaminated with sludgc--REMOVE using a damp cloth. VIDEO TAPE the sludge layer under an ultraviolet lamp to verify the Magna-flux tracers.

3.0 RECORD the processor connector and process valve INTERMEDIATE weight.

4.0 INSTALL the process valve to its open position in the mounting apparatus. INSTALL and TORQUE process connect to $40 \mathrm{ft}$. lbs. using a criss-cross pattern in asending torque stages and a final check around the bolts. (Note: Use unlubed condition, per HNF-N-62 Multi-Canister Overpack Component Testing, Vol. 1, Ruff, 1997). on the mounting apparatus

5.0 START the ejector flow pump and ALLOW flow to stabilize. OPEN air isolation valve. OPEN the isolation valve to the ejector. OPEN the DI water isolation valve.

6.0 FLUSH the system for 5 minutes, OBSERVE process connector exterior for indications of water being forced passed the any $O$-Ring seals.

70 ISOLATE DI water and air sources THEN STOP the ejector flow pump, and THEN close the isolation valve to the cjector. NOTE: This scquence must be followed to assure the system stays as dry as possible

8.0 REMOVE process connector and VIDEO TAPE inspection with an ultraviolet lamp to identify any remaining sludge traps in the process connector. RECORD observations in logbook. REMOVE 
process connector and VIDEO TAPE inspection with an ultraviolet lamp to identify any remaining sludge traps in the process connector. RECORD observations in logbook.

9.0 RECORD the process connector and process valve FINAL weight.

10.0 IF MagnaFlux is observed in areas of the process connector and process valve internals

11.0 REPEAT steps 3 through 10 but increase the flush time 5 minutes on each repeat test and RECORD observations and times in logbook until the connector is flushed clean with no visible indications of the MagnaFlux tracer.

12.0 CLEAN the process connector, RE-APPLY sludge as described in steps 1 and 2 and REPEAT steps 3 through 10 at the flush time determined in step 11.0. REPEAT at test director discretion.

13.0 INSPECT process connector O-Rings under a bench top microscope for abrasion damaged and RECORD observations in test log.

14.0 NDE lcak check process connector to be leak tight to $1.0 \times 10^{-6} \mathrm{std} \mathrm{cc} / \mathrm{sec} \mathrm{He}$.

\begin{tabular}{ll}
\hline Test Engineer & Date \\
\hline NDE & Datc
\end{tabular}

\subsubsection{Valve Sealing Test}

1.0 NDE COMPLETE a leak check of the ejector isolation valve to $1 \times 10^{-4} \mathrm{~cm}^{3} / \mathrm{s} \mathrm{He}$. PLACE leak check report in the log book and SUMMARIZE results in Appendix I.

\begin{tabular}{l|l}
\hline NDE & Datc \\
\hline Test Enginecr & Datc
\end{tabular}

2.0 MIX a liquid sludge per test engincer's dircction using water, Kaolin, and/or Minusil with a Magnaflux as a tracer additive. Note Mixture "recipe" in logbook and VIDEO TAPE consistency.

Sludge Preparation

$\frac{1}{\text { Test Engineer }}$ Date

3.0 REMOVE the drop out tank from the mounting apparatus and REPLACE with tubing into the container with liquid sludge.

4.0 START the ejector flow pump and ALLOW flow to stabilize. OPEN the isolation valve to the ejector.

5.0 During the removal of the sludge, ACTUATE the ejector isolation valve 5 to 10 times. 
6.0 OPEN DI water isolation valve. During flushing, ACTUATE the ejector isolation valve 5 to 10 times.

7.0 ISOLATE DI water and cjector valve

8.0 REMOVE cjector isolation valve from system. NDE COMPLETE a leak check of the ejector isolation valve to $1 \times 10^{-1} \mathrm{~cm}^{3} / \mathrm{s}$ He. PLACE leak check report in Appendix I and SUMMARIZE results.

$\begin{array}{ll}\text { NDE } & 1 \\ \text { Test Engineer } & \text { Date }\end{array}$

\subsubsection{Hood Ventilation Test}

The process ventilation hood air flow measurements shall be conducted using a scale mock-up. This test is to establish that no eddy currents are produced while an operator is in front of the hood causing possiblc contamination to be spread in the operator breathing space. This test shall be conducted by a qualified vent and balance group using a manikin(s) and smoke tests to establish the air flow patterns. The apparatus will have to be set-up to supply the current design specified hood flow rate and hood face obstructions

\subsubsection{Prerequisites}

1.0 ASSEMBLE/FABRICATE test apparatus per test engineer's direction. ADJUST dampers until design flow of $1300 \mathrm{scfm}$ is achieved.

Apparatus fabrication

$\frac{1}{\text { Test Engineer }}$ Date

2.0 SCHEDULE Vent and Balance to perform an open faced hood ventilation test with two to three people standing in front of the open faced hood.

3.0 SCHEDULE Industrial Safcty to provide noise level determination.

4.0 Video tape smoke test.

\subsubsection{Instructions for Ventilation and Noise Test}

1.0 Vent and Balance ESTABLISH hood capture velocity of 125 FPM.

2.0 PLACE personnel or manikins (3) in the expected working space in front of the hood. NOTE personnel locations on location map provided in Log Book

30 Smoke TEST pursuant to Vent and Balance procedure (to be provided by V \& B) and video tape results. 
4.0 ADJUST flow as necessary to maintain particulate capture and minimizc personnel exposure.

5.0 RECORD final flow rate settings and capture velocities in Log Book

6.0 Industrial Safety ESTABLISH noise level readings at working distance and DETERMINE safe distances for personnel without hearing protection. RECORD preliminary findings in Log Book.

\subsubsection{Seal Ring Performance Testing}

\subsubsection{Prerequisites}

1.) INSTALL MCO in the cask.

2.0 INSTALL scal ring on cask and tighten bolts to 25-30 ft. lbs.

3.0 INFLATE inflatable O-Rings in the seal ring to 25 to 35 psig and RECORD setting.

\subsubsection{Instructions}

1.0 PRESSURIZE the cask to $25 \mathrm{psig}$ ( \pm lpsig) as necessary. NOTE: The MCO will float upwards approximately lin. inside the cask until contact is established with the seal ring.

2.0 NDE DETERMINE leak rates through the MCO inflatable O-Ring, O-Ring seal plate bottom Oring, and the O-Ring seal plate bore seal O-ring. Use drawings H-1-83264 sht. 1-2 and H-1-83275 sht 1-3 of Process Hood, Seal Ring and Piping Assembly W-441-P4 Rcv. N Procurement Spccification as necessary for reference.

MCO inflatablc O-Ring leak ratc std co/sec He

O-Ring scal plate bottom O-ring leak ratc std cc/sec He

O-Ring seal plate bore seal O-ring leak rate std $\mathrm{cc} / \mathrm{sec} \mathrm{He}$

PLACE leak test report in Appendix I

Seal Ring Leak rate establishment

\begin{tabular}{lll}
\hline NDE & Date \\
\hline Test Enginecr & Date
\end{tabular}

\subsubsection{First Article Testing Apparatus}

In conjunction w/section 8.1.3 the VPS/TWS processing skid has been delivered and installed in the 306E Facility First Article Test Bed.

$\frac{1}{\text { Test Director Datc }}$




\subsubsection{MCS Computer Control Setup and Testing}

A substantial amount of time and effort is planned to setup and test the control system. Since all programming has been done without physical connections to the process equipment, many required program changes are expected. The MCS used in first article testing will be "first generation" and will provide the minimum capability required to perform the planned testing.

As part of the first article testing of the MCS, the hardware will be verified during the Construction Acceptance Test \# RDC/DESH MCB-SLB-A06285-CAT-000 MCS Hardware Construction Acceptance Test in the $306 \mathrm{E}$ Building facility. The CAT tests will provide: loop calibrations; data logging; data storage; and demonstrate data transfer utilizing Intellution software. The actual MCS programmed sequences and automatic functions will be tested as part of the $306 \mathrm{E}$ Test Procedures. Included in these tests will be the drain sequence and as much of the proposed vacuum drying steps as available at the start of testing. Other steps or sequences will be added as soon as they are defined; those added during the $306 \mathrm{E}$ testing will be tested at that time. Since the recirculation mode is under consideration for elimination no automatic sequences will be programmed at this time; however, manual control will be provided. A small subset of the total alarms will be programed, basically only those necessary to support continued testing at the $306 \mathrm{E}$ facility without the need for continuous staffing. Interlocks for the TWS heater will be provided at a minimum. Other alarms and off-normal automatic responses are not available at this time and will be programmed as they become available.

MCS Construction Acceptance Test and mockup systems operational testing complete.

\begin{tabular}{lc}
\hline Control Systems Engineer & Date \\
\hline Test Director & Date
\end{tabular}

\subsection{FIRST ARTICLE TESTING}

The following tests identify specific operating temperatures, pressures, flows, bulk water amounts, however the parameters may change or be changed during the testing phase. These changes will be documented in the test log.

The test apparatus for prototype or first article testing consists of a full size prototypic $\mathrm{MCO}$ (which for the purpose of this section, will be referred to as the $\mathrm{MCO}$ ) and transportation cask (with mockup hood/scal ring and lower port connector assembly) connected to the first article VPS and TWS. Also connected to the first article VPS/TWS are prototypes of the PWC, the SCHe system, an equivalent process chiller system; all shall be controlled and operated utilizing a first generation MCS. The MCO and 'systems' shall be connected with prototype process connectors and equivalent length piping. The MCO will require instrumentation feed throughs (hermetic) to determine test article temperaturcs

A set of preliminary and first article proof of performance CVD tests are summarized in Appendix A. Details of the preliminary and first article tests are provided in this section. These tests are intended to provide the necessary data to aid in system operation, to optimize I \& $\mathrm{C}$ control and software process functions, and to demonstrate safe system operation durıng normal operation and some accident, upset and faulted conditions. These tests may be removed or other tests may be substituted from the testing program per the change control previously identified in section 5.3.2.

The general service process instrumentation and control system performance will be tested and edited 
mainly during the preliminary test sequence. Any control system changes that are observed during testing shall be documented on a Request for Information (RFI) and in the test log book and transmitted to the I \& C vendor for software implementation and the changes shall be reinstalled during a test reconfiguration or shut down interval, unless the changes are necessary for test completion and will not violate test data integrity. The general scrvice 1 \& $\mathrm{C}$ testing will be required to examine a small percentage of the normal, accident, upset, and faulted mode responses and fail safe positions of accident scenarios. These scenarios include: line breakage and oxygen ingress, loss of instrument air, and loss of electrical power at different times during the process sequence.

The safety class I \& C (SCIC) performance will not be tested as part of the first article testing. Jumpers will be installed to allow the general service I \& $\mathrm{C}$ to operate normally and act as the SCIC. The safety class helium injection system will be tested under a small percentage of the normal, accident, upset, and faulted mode responses and fail safe positions of different accident scenarios. These scenarios include: line brcakage and oxygen ingress, loss of instrument air, and loss of electrical power at different times during the process

VPS/TWS skid, process hood, PWC, MCO and MCS are ready for processing.

Hold Point

\begin{tabular}{lc}
\hline Test Director/Engineer & Date \\
& Date
\end{tabular}

\subsection{PRIMARY MANUAL SEQUENCES OF OPERATION}

The following CVD first article tests can often be described in terms of permutations of MCO fuel mockup conditions and a particular type of test cycle. Each of these cycles may use different hardware components (vacuum pump, condenser, etc.) operated at different test parameters (temperature, flow rate, etc.).

\section{Special Prerequisites}

When using computer manual sequencing, as described in this section, the valves that are referenced are to be actuated in the order in which they are listed. Any changes to this order, a test exception or red line change shall be required and noted in the testing log

Main Line Break Valves MLB-V-P001 to P004 shall REMAIN CLOSED throughout the procedure unless otherwise stated in the procedure

\subsubsection{Bulk Water Drain Sequence}

\subsubsection{Prerequisites}

1.0 OPEN GOV 4045 GOV 4046, and PWC-S-P001.

2.0 Pump PWC-P-4035 is ON

3.0 INSURE MINIMUM water level in the PWC tank AND RECORD water level. 


\subsubsection{Special Requirements}

1.) OBSERVE FI 4050 and PI 4034 for initial breakthrough (indicates draining finished) of water level. The pressure is expected to rise quickly from vacuum to atmospheric pressurc. The flow is expected to rise slightly just as the gas breaks through the system.

\subsubsection{Instructions}

1.0 CLOSE valves GOV 2221, 2222, 1206, 1217, 2204, 2205, 2207, PWC-R-P001, CV-BPV-P001, CV-BPV-P001, IXM-IV-P00I and IXM-IV-P002.

2.0 OPEN valves GOV 2203, 1209, 1212, 1230, 1201, and IXM-BPV-P001

3.0 PRESSURIZE MCO through HEPA filter port to 4 PSIG (PI 1236).

4.0 OBSERVE for MCO breakthrough as indicated in 9.1.1.2. HOLD gas flow for approximatcly 5 minutes.

5.0 RECORD final PWC tank level.

6.0 CONTINUE with scction 9.1 .2 as directed by the test engineer.

\subsubsection{Bulk Water DI Rinse (PWC Line Flush)}

1.0 DRAIN the PWC tank to MINIMUM level AND RECORD level.

2.0 PRESSURIZE MCO to 4 PSIG.

3.0 OPEN GOV 2203, 2204, 1212, 1230, 1209, 1201, 1202, 1217, and MOV 1211 goes to DI water side.

5.0 CLOSE GOV 2228.

6.0 FLUSH PWC lines for 15 minutes.

7.0 CLOSE GOV 1201, 1230, 1209, 1212, 1204, 2203, 1202, 1217, and MOV 1211 .

\subsubsection{Tempered Water Heatup}

1.0 CLOSE GOV 1215

2.0 OPEN GOV 3214, 1214.

3.0 START pump TW-P-3214

4.0 SET heater TW-HTR- 3211 at $50^{\circ} \mathrm{C}$. 


\subsubsection{Helium Purge or Repressurize Cycle (Diptube Inlet) \\ 1.0 SET flow controller FIC 1219 at 1.6 or $10 \mathrm{scfm}$ (purge flow or quick repressurization respectively). \\ 2.0 OPEN valves GOV 1202, 1209, 2203, 2204, and 1206 \\ 3.0 CLOSE valves GOV $1217,1212,1230,2221,2222,2207$, and 2205}

\subsubsection{Vacuum Drying with Condenser}

\subsubsection{Prerequisite}

1.0 Vacuum Pump VPS-P-2211 is ON with helium purge.

20 TWS is opcrating and maintaining set point (typically $50^{\circ} \mathrm{C}$ ).

3.0 Bulk water has been DRAINED (section 9.1.1) from MCO (as directed by the test director).

4.0 VPS CHW operating at specified flow and temperature (typically 4 gpm and TT 2236 indicates $2^{\circ} \mathrm{C}$ ).

5.0 Condenser tank (VPS-TK-2216) has been DRAINED (section 9.1.12).

6.0 SET FIC 1219 at $1.6 \mathrm{scfm}$ and OPEN GOV 1206, 1202, 1209, 2222, 2221, and 2204.

\subsubsection{Instructions}

1.0 OPEN GOV 1209, 2207, 2221, and 2222

2.0 CLOSE GOV 1217, 1230, 2204, 2203, and 2205.

3.0 IF the temperature difference $(\Delta \mathrm{T})$ between TI 2235 and Tl 2236 is $<2{ }^{\circ} \mathrm{C}$, CLOSE GOV 2222 , 2221 and OPEN 2203 to isolate the condenser (VPS-COND-2213)

4.) REDUCE FIC 1219 to $0 \mathrm{scfm}$ and CLOSE valve GOV 1206.

5.0 CONTINUE with vacuum pump only drying until PI 1208 is LESS THAN 0.1 torr.

\subsubsection{Vacuum Drying without Condenser}

\subsubsection{Prerequisites}

1.0 Vacuum pump VPS-P-2211 is ON with helium purge.

2.0 TWS is operating and maintaining set point (typically $50^{\circ} \mathrm{C}$ ).

3.0 Bulk water has been DRAINED (section 9.1.1) from MCO (as directed by the test director).

4.) SET FIC 1219 at $1.6 \mathrm{scfm}$ and OPEN GOV 1206, 1202, 1209, 2222, 2221, and 2204. 


\subsubsection{Instructions}

1.0 OPEN GOV 1209, 2207, and 2203

2.0 CLOSE GOV 2222, 2221, 1217, 1230, and 2204

\subsubsection{Normal Vacuum Drying Cycle (8-4-4 Sequencing)}

Full 8-4-4 Cycle Vacuum pump operated for 8 hours with condenser and helium purge (at $1.6 \mathrm{scfm}$ ), followed by a 4 hour helium recycle or purge (at $10 \mathrm{scfm}$ then $1.6 \mathrm{scfm}$ ), followed by 4 hours of vacuum pump only operation with helium purge (at $1.6 \mathrm{scfm}$ ). The 4 hour cycles are repeated until the MCO is "dry".

\subsubsection{Prerequisites}

1.0 Vacuum Pump VPS-P-2211 is $\mathbf{O N}$ with helium purge.

2.0 TWS is operating and maintaining set point (typically $\left.50^{\circ} \mathrm{C}\right)$.

3.0 Bulk water has been DRAINED (section 9.1.1) from MCO (as directed by the test director).

4.) VPS CHW operating at specified flow and temperature (typically 4 gpm and TT 2236 indicates $2{ }^{\circ} \mathrm{C}$ ).

5.0 Condenser tank (VPS-TK-2216) has been DRAINED (section 9.1.12)

6.0 SET FIC 1219 at $1.6 \mathrm{scfm}$ and OPEN GOV 1206, 1202, 1209, 2222, 2221, and 2204

\subsubsection{Vacuum Drying with Condenser (8 hour cycle)}

Condenscr/Purge Only Vacuum Pump and Condenser Operation $\left(1{ }^{\circ} \mathrm{C}\right)$ with Helium Purge at Cycle $1.6 \mathrm{scfm}$ for 8 hours.

1.0 SET FIC 1219 to $4 \mathrm{scfm}$.

2.0 OPEN GOV 1209 and 2207.

3.0 CLOSE GOV 1217, 1230, 2204, 2203, and 2205 .

4.) CONTINUE $4 \mathrm{scfm}$ helium flow for 10 minutes to reduce steam flow through the MCO internal HEPA filters.

5.0 REDUCE helium flow. ADJUST FIC 1219 to $1.6 \mathrm{scfm}$.

6.0 IF time is 4 hours under vacuum AND $\Delta$ T between TI 2235 and TI 2236 is LESS THAN $2{ }^{\circ} \mathrm{C}$ THEN OPEN 2203 AND CLOSE GOV 2222, 2221, 1202, and 1206 to bypass and isolate the condenser (VPS-COND-2213) and stop the helium purge.

7.0 IF pressure in MCO is GREATER THAN 9 torr AFTER 5 minutes from the condenser bypass, OPEN GOV 1206 and 1202 to resume vacuum drying with purge but without condenser UNTIL the 
time under vacuum is 7.5 hours.

8.0 IF time under vacuum EQUALS 7.5 hours THEN GOTO section 9.1.7.3.

NOTE: Stcp 8.0 applies to all steps in this section.

9.0 IF the tempcrature difference ( $\Delta$ T) between TI 2235 and TI 2236 is GREATER THAN $2{ }^{\circ} \mathrm{C}$ AND time under vacuum is LESS THAN 7.5 hours, THEN CONTINUE the evacuation.

10.0 IF time is LESS THAN 7.5 hours under vacuum AND $\Delta$ T between TI 2235 and TI 2236 is LESS THAN $2{ }^{\circ} \mathrm{C}$ THEN OPEN 2203 AND CLOSE GOV 2222, 2221, 1202, and 1206 10 bypass and isolate the condenser (VPS-COND-2213) and stop the hclium purge

11.0 IF pressure in MCO is GREATER THAN 9 torr AFTER 5 minutes from the condenser bypass, OPEN GOV 1206 and 1202 to resume vacuum drying with purge but without condenser UNTIL the time under vacuum is 7.5 hours.

12.0 IF pressure (PT 1208) decrcases in pressure and can be maintained BELOW 0.1 torr for 15 minutes, GOTO section 9.1.7.5. OTHERWISE OPEN GOV 1206 and 1202 to resume vacuum drying with purge but without condenser UNTIL the time under vacuum is 7.5 hours.

\subsubsection{Helium Recycle (Purge Cycle- 4 hours)}

Only a helium recycle or purge at $10 \mathrm{scfm}$ then reduced to $1.6 \mathrm{scfm}$ is performed to dry the MCO for 4 hours.

1.0 CLOSE GOV 2207

2.0 SET FIC 1219 at $10 \mathrm{scfm}$

3.0 OPEN GOV 1209, 2221, 2222, and 2204 to valve in the condenser

4.0 CLOSE GOV 1217, 1230, 2203, 2205, and 1212

5.0 AFTER 5 minutes of $10 \mathrm{scfm}$ purge flow REDUCE FIC 1219 to $1.6 \mathrm{scfm}$.

6.0 AFTER 3 hours 55 minules of purging, GOTO 9.1.7.4

\subsubsection{Vacuum Drying without Condenser (4 hour cycle)}

Condenser/Purge Only Vacuum Pump and Condenser Operation $\left(1^{\circ} \mathrm{C}\right)$ with Helium Purge at Cycle $1.6 \mathrm{scfm}$ for 4 hours.

1.0 INCREASE FIC 1219 to $4 \mathrm{scfm}$.

2.0 OPEN GOV 1209, 2204, and 2203.

3.0 CLOSE GOV 1217, 1230, , 2203, 2205, 2207, 2221, and 2222.

4.0 AFTER 30 minutes of 4 scfm flow, CLOSE GOV 2204, OPEN 2207, AND REDUCE flow to 1.6 scfm for 15 minutes. 
5.0 CLOSE GOV 1202 and 1206 to stop helium flow.

6.0 IF time under vacuum EQUALS 3.5 hours THEN GOTO section 9.1.7.3.

NOTE: Step 6.0 applies to all steps in this section.

7.0 IF pressure in MCO is GREATER THAN 9 torr AFTER 5 minutes from the condenser bypass, OPEN GOV 1206 and 1202 to resume vacuum drying with purge but without condenser UNTIL the time under vacuum is 3.5 hours THEN REPEAT section 9.1.7.3.

8.0 IF pressurc (PT 1208) decreases in pressure and can be maintained BELOW 0.1 torr for 15 minutes, GOTO section 9. 1.7.5, OTHERWISE OPEN GOV 1206 and 1202 to resume vacuum drying with purge but without condenser UNTIL the time under vacuum is 3.5 hours THEN REPEAT section 9.1 .7 .3

\subsubsection{Pressure Rebound Test}

NOTE: IF time under vacuum ( $7.5 \mathrm{hrs}$ or $3.5 \mathrm{hrs}$. section 9.1 .7 .2 or 9.1 .7 .4 respectively) is exceeded at any time during these following steps GOTO 9.1.7.3

1.0 ISOLATE MCO. CLOSE GOV 1230, 1202, 1206, and 1209.

2.0 MONITOR PRESSURE over 10 MINUTES

3.0 IF pressurc RISE is GREATER THAN 0.5 TORR in 10 minutes, RESUME vacuum drying with purge but without condenser. OPEN GOV 1209, 1202, 1206 AND INCREASE purge to $1.6 \mathrm{scfm}$ to continue vacuum drying without condenser UNTIL the time under vacuum is exceeded $(7.5 \mathrm{hrs}$ or 3.5 hrs section 9 1.7.2 or 9.1.7.4 respectively).

NOTE: IF returning to section 9.1.7.4, REPEAT steps 1.0 through 3.0 of this section EVERY HOUR UNTIL the step 3.0 CANNOT be met, THEN CONTINUE with step 4.0.

4.0 ISOLATE MCO. CLOSE GOV 1230, 1202, 1206, and 1209

5.0 MONITOR PRESSURE over 1 HOUR

6.0 IF pressure RISE is GREATER THAN 3 TORR in lhour, RESUME vacuum drying with purge but without condenser. OPEN GOV 1209; 1202, 1206 AND INCREASE purge to $1.6 \mathrm{scfm}$ to continue vacuum drying without condenser UNTIL the time under vacuum is exceeded ( $7.5 \mathrm{hrs}$ or 3.5 hrs section 9.1 .7 .2 or 9.1 .7 .4 respectively).

7.0 IF pressure RISE is LESS THAN 3 TORR in 1 hour, the MCO is DRY AND the test is COMPLETE. CONTACT test director or test engineer 


\subsubsection{Proof Drying Mode}

\subsubsection{Prerequisites}

1.) MCO is LESS THAN 9 torr AND is DRY.

2.0 TWS is operating at $50^{\circ} \mathrm{C}$ (Hot standby mode).

\subsubsection{Instructions}

1.0 RETURN to vacuum purge without condenser mode and without purge. CLOSE GOV 1202, 1230, 1217,2221 , and 2222 AND OPEN GOV 1209, 2203, and 2207

2.0 MAINTAIN vacuum lcvels below $<9$ torr for 19 hours (should be less than 0.5 torr).

3.0 IF pressure RISES above 9 torr within 2 hours, a system leak has occur and repair is required CONTACT test director

4.0 AFTER 19 hours, ISOLATE MCO. ClOSE GOV 1209

5.0 CONFIRM pressure RISE is LESS THAN 3 TORR in 1 hour. The MCO is DRY AND the test is COMPLETE.

6.0 REPRESSURIZE the MCO to $1-5 \mathrm{psig}$. SET FIC 1219 to $0.5 \mathrm{scfm}$ AND OPEN GOV 1206 and 1202.

7.0 MONITOR PT 1236 until I-5 psig is met THEN CLOSE GOV 1206 and 1202.

\subsubsection{MCO Cooling}

\subsubsection{Prerequisites}

1.0 MCO is at $50 \% \mathrm{C}$ or at discretion of the test engineer and noted in the logbook.

2.0 MCO is filled with Helium at $1-5$ psig.

\subsubsection{Instructions}

1.0 SET the Tempered Water Heater controls (TIC 3205) to $25^{\circ} \mathrm{Cor}$ at the discretion of the test engineer AND OPEN GOV 3201 for TW cooling flow UNTIL the TT 3212 and the MCO shell TCs (TE 6-10) reach LESS THAN $25^{\circ} \mathrm{Cor}$ at the discretion of the test engineer. (NOT to be below $10^{\circ} \mathrm{C}$ and noted in the test logbook.)

2.0 When temperature is achicved, increase MCO pressure to $7.3 \pm 1.5 \mathrm{psig}$. SET FIC 1219 to $0.5 \mathrm{scfm}$ AND OPEN GOV 1206 and 1202 .

3.0 MONITOR PT 1236 until $7.3 \pm 1.5 \mathrm{psig}$ is met THEN CLOSE GOV 1206, 1202, and 3201 . 
HNF-2402

Rev. 0

\subsubsection{MCO Water Fill}

First article testing requires the MCO to be filled to certain levels or certain volumes of water without removing the MCO shield plug. The following steps will dictate how this process can be done safely without damage to the equipment or submerging the MCO internal filters.

\subsubsection{Computer Manual Water Fill for Large Quantities of Water}

\subsubsection{Prerequisites}

1.() SHUT OFF pump PWC-P-4035

2.0 CLOSE GOV 4046 and 4045

\subsubsection{Instructions}

1.0 FILL the EMPTY WRT with the specified amount of water PLUS 20 gallons to offset the WRT dip leg measurement.

2.0 START the vacuum drying with condenser manual operation as referred to in section 9.1.5.

3.0 ALLOW the system pump to $\sim \mathbf{1 0 0}$ Torr.

4.0 ISOLATE the MCO by CLOSING GOV 1209.

5.0 Manually OPEN the check valve bypass valve in the PWC/Hood spool piecc.

6.0) ISOLATE the IXM and place into IXM bypass by CLOSING IXM-IV-P001 and P002 and OPENING IXM-BPV-P001

7.0 OPEN GOV 1230. This allows water begin flowing into the MCO.

8.0 OBSERVE the WRT until the WRT indicates approximate the water quantity or the WRT level is below the WRT dip leg.

9.0 RECORD the amount of water in the PWC/MCO system in the test log book.

10.0 CLOSE the IXM bypass valve IXM-BPV-P001.

11.0 WAIT approximately 5 minutes.

12.0 CLOSE GOV 1230

13.0 VENT MCO per section 9.1.11

\subsubsection{Manual Water Fill for Small Volumes of Water}

1.) OPEN the MCO boroscope inspection port. 
2.0 FILL with desired amount of water utilizing a funnel.

3.0 RECORD the amount of water in the MCO in the appropriate test log book.

4.0 CLOSE the MCO boroscope inspection port.

\subsubsection{MCO Venting}

\subsubsection{Prerequisites}

1.0 CLOSE GOV 2207 to isolate vacuum pump VPS-P-2211

\subsubsection{Manual MCO Only Venting Instructions}

1.0 Computer manual CLOSE GOV 1230, 1202, and 1209

2.0 OPEN MCO boroscope port.

3.0 ALLOW MCO vent UNTIL MCO pressure is at atmosphere

4. CLOSE MCO boroscope port.

\subsubsection{Manual System and MCO Venting}

1.0 OPEN main linc break valve MLB-V-P00I

2.) ALLOW MCO vent UNTIL MCO pressure is at atmosphere

3.0 CLOSE MCO MLB-V-P001.

Note: For system only venting, if necessary, without venting MCO, CLOSE both MCO port valves using the process connectors.

\subsubsection{Condenser Tank Drain Instructions}

\subsubsection{Prerequisites}

1.0 OPEN GOV 4045 and GOV 4046.

2.0 Pump PWC-P-4035 is $\mathbf{O N}$

3.0 INSURE MINIMUM water level in the PWC tank AND RECORD water level.

9.1.12.2 Instructions

1.0 CLOSE GOV $1230,1202,1209,2203,2207,2205$, and 2222. 
2.0 OPEN 2204, 2221, 1212, and 2216 to hclium purge and drain condenser tank (VPS-TK-2216).

3.0 CONTINUE condenser tank drain UNTIL break through occurs as indicated by PI 4034.

4.0 CLOSE GOV 1212,2221, 2204, and 2216

\subsection{BASELINE ESTABLISHMENT}

This testing of the dry MCO shall establish initial system vacuum baselines and overall system operational verification for determining VPS/MCO system evacuation times for thermal model verification (i.e., Process Simulator), MCO baseline dryness for pressure and moisture sensors, VPS/MCO system leakage, and system off-gassing for the RGA baselines. The baseline establishment will also verify operation of the Helium purge and recirculation systems, tempered water syetem, the PWC eductor (section 9.5), gas operated valves, pressure control valves, flow control valves, and temperature set points.

\subsubsection{Prerequisites}

1.) RECORD obscrvations in logbook.

2.0 All other system starting prerequisites in sections 8.2.7 and 8.2.8 have been completed.

NOTE: These tests will be conducted with a clean, dry, and empty MCO.

\subsubsection{Vacuum Baseline Establishment Instructions}

1.0 CONDUCT MCO Heating by referring to tempered water heating section 9.1 .3 for heating instructions.

2.0 CONDUCT vacuum drying with condenser utilizing vacuum drying sequence with condenser or manually use section 9.1 .5 .

3.0 MONITOR and RECORD system pressures, tempcratures, dewpoint, RGA parameters and time in the test log. Observations such as: times of visibly changing slope in pressure and tempcratures; visible changes such as $\mathrm{MCO}$ deformations.

4.0 OPEN GOV 2203 and CLOSE GOV 2221 and 2222.

5.) VENT entire system to almosphere and REPEAT step I one additional time and RECORD data in the test log.

Vacuum Baseline Establishment Complete and Acceptance Criteria of system base pressure of 0.1 torr OR LESS in LESS THAN 1 hour.

$\frac{1}{\text { Test Engineer }}$

Witness Point

Design Authority




\subsubsection{Helium Purge Baseline Establishment}

1.0 CONDUCT MCO Heating by referring to tempered water heating section 9.1 .3 for heating instructions

2.0 CONDUCT helium purge utilizing helium purging sequence or manually use section 9.1.4.

3.0 MONITOR and RECORD system pressures, temperatures, dewpoint, RGA parameters and time in the test log. Observations such as: times of visibly changing slope in pressure and temperatures; visible changes such as $\mathrm{MCO}$ deformations.

4.0 VENT entire system to atmosphere.

Helium Purge Baseline Establishment Complete

$\frac{1}{\text { Test Engineer }}$

\subsubsection{Helium Recycle Baseline Establishment}

1.0 CONDUCT MCO Heating by referring to tempered water heating section 9.1 .3 for heating instructions

2.0 USE helium recycle sequence and procede to step 5.0 OR OPEN GOV 2228, 1217, 1202, 1209, 2203. 2204, and MOV 1211 SET to He side. PROCEDE with steps 3.0, 4.0, and 5.0.

3.0 CLOSE GOV 1206, 2222, 2221, 2207, and 2205.

4.0 START Hclium pumps VPS-P-2205 and VPS-P-2206.

5.0 MONITOR and RECORD system pressures, temperatures, dewpoint, RGA parameters and time in the test $\log$. Observations such as: times of visibly changing slope in pressure and temperatures; visible changes such as $\mathrm{MCO}$ deformations.

Helium Recycle Baseline Establishment Complete

$\frac{1}{\text { Test Engineer }}$

\subsection{E UPSET CONDITIONS TESTS}

The purpose of these tests is to demonstrate that the system(s) will reach a safe shut down condition in the $306 \mathrm{E}$ building from four specific upset conditions. The shutdown response of the system shall be tested with respect to loss of 1) electrical power, 2) loss of the computer, 3) loss of system vacuum and 4) heater remote shutdown. A safe shutdown of the unmanned system during vacuum drying in $306 \mathrm{E}$ is defined as: the state where the MCO is slightly pressurized ( $0.5 \mathrm{psig})$ with a helium purge.

\subsubsection{Prerequisites}

1.0 Record observations in logbook. 


\subsubsection{LOEP without Loss of Computer Instructions}

10 With an EMPTY MCO, OPERATE a Vacuum w/ Condenser sequence manually as described in section 9.1 .5 or automatically.

2.0 SWITCH VPS AND TWS skid main powers OFF.

3.0 OBSERVE and RECORD skid responses such as: Valve failure positions; Water backflow characteristics; Tank levels and SCHe operations.

LOEP Upset Complete

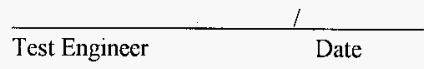

\subsubsection{Loss of Computer Instructions}

1.0 With an EMPTY MCO, OPERATE a Vacuum w/ Condenser sequence manually as described in section 9.1 .5 or automatically.

2.0 SWITCH MCS main powers OFF.

3.0 OBSERVE and RECORD skid responses such as: Valve failure positions; Water backflow characteristics; Tank levels and SCHe operations.

Loss of Computer Upset Complcte

$\frac{1}{\text { Test Engineer }}$

\subsubsection{Loss of System Vacuum (Non-Vacuum Pump Failure) Instructions}

1.0 With an EMPTY MCO, OPERATE a vacuum with CONDENSER BYPASSED sequence manually as described in section 9.1 .6 or automatically.

2.0 ISOLATE the Safety Class Helium Injection system such that it DOES NOT operate.

3.0 Using the PLC and software to simulate a OPEN FV 1219 UNTIL system pressure above 140 TORR as indicated by PI 2209.

4.0 OBSERVE systcm for 10 minutes. Vacuum pump VPS-P-2211 should power down. Loss of Vacuum Upset Completc

$\frac{1}{\text { Test Engineer } \quad \text { Date }}$

\subsubsection{Heater Upset Shutdown}

1.0 START TW-P-3214 and OPEN GOV 3214 and 1214

2.0 ADJUST the Tempered Watcr Heater TW-HTR-3211 to $50^{\circ} \mathrm{C}$

3.0 As process temperature is rising, STOP TW-P-3214 by switching off the pump at the electrical power distribution panel. 
4.0 VERIFY power to the heater controller TC 3205 has been interrupted.

Heater Upset Complete

$\frac{1}{\text { Tcst Engineer } \quad \text { Date }}$

\subsection{THIRTY-TWO LITER RESIDUAL WATER DRYING TEST}

Thirty-two (32) liters of water shall be placed into the MCO, then heated to a temperature (nominally $50^{\circ} \mathrm{C}$ ) with the TWS, and evacuated and dried using the VPS vacuum pump with the condenser operating at $1^{\circ} \mathrm{C}$. This test provides basic information such as water temperature and pressures inside the MCO to cstablish design performance and for the thermal model verification without additional complications such as fuel, water in isolated locations, and sludge.

\subsubsection{Vacuum Pump Only Drying Instructions}

1.) START the tempered water heating at a set point of $50^{\circ} \mathrm{C}$ using section 9.1 .3 for manual start (if not already started).

2.0 ADD 32 liters $(+/-0.5 \mathrm{I})$ of heated $\left(\sim 50^{\circ} \mathrm{C}\right)$ water using steps outlined in section $9.1,10$.

HP 32 liters added

\begin{tabular}{lc} 
& $/$ \\
\hline Test Engineer & Date \\
\hline QC & Date
\end{tabular}

3.0 BEGIN vacuum drying sequence with condenser bypassed (section 9.1.8) or computer manual sequence

4.0 CONTINUE test until PT 1208 indicates less than 0.5 torr.

5.0 ISOLATE MCO by CLOSING GOV 1202, 1230, and 1209

6.0 IF pressurc rcbound is greater than 3 torr in one hour ( 0.75 torr in 15 minutes), RETURN to vacuum drying by opening GOV 1202, 1230, and 1209 .

7.0 IF rebound test is successful, VENT MCO by steps outlined in section 9.1 .11 and INSPECT the MCO interior with the boroscope. ENSURE surfaces are dry and not frozen. RECORD observations and data file in logbook

\subsubsection{Normal Operation Drying Instructions}

1.0 START the tempered water heating at a set point of $50^{\circ} \mathrm{C}$ using section 9.1 .3 for manual start (if not already started)

2.0 ADD 32 liters $(+/-0.51)$ of heated $\left(\sim 50^{\circ} \mathrm{C}\right)$ water using steps outlined in section 9.1 .10 
HP 32 liters added

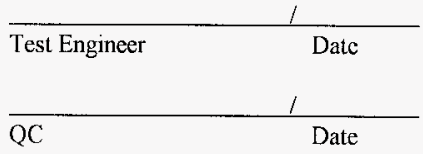

3.0 BEGIN 8-4-4 vacuum drying sequence or computer manual sequence per section 9.1.7

4.) CONTINUE test until PT 1208 indicates less than 0.5 torr.

5.0 ISOLATE MCO by CLOSING GOV 1202, 1230, and 1209.

6.0 IF pressure rebound is greater than 3 torr in one hour ( 0.75 torr in 15 minutes), RETURN to vacuum drying by OPENING GOV 1202, and 1209.

7.0 IF rebound test is successful, VENT MCO by steps outlined in section 9.1.11 and INSPECT the MCO interior with the boroscope. ENSURE surfaces are dry and not frozen. RECORD observations and data file name in logbook.

\subsection{BULK WATER REMOVAL AND TOTALIZATION}

Bulk water removal may be accomplished by pumping the free water from the vacuum vessel utilizing the prototype bulk water removal pump (eductor), or by pressurizing the vacuum chamber with either compressed air or inert gas, or a combination of methods. For determining (roughly) the amount of bulk water removed from the $\mathrm{MCO}$ (totalization) during this process, the water will be pumped into an empty totalizing vessel. During first article testing, bulk water removal and totalization will utilize (MCO) pressurization with helium, and evacuation with the PWC with the IXM pre-filter bypassed. The water retention tank will be utilized to determine the amount of water removed, allowing a determination of the amount remaining in the system. It is estimated that roughly 32 liters of residual water will remain after the bulk water has been removed. Once the remaining cycle for a given drying test is completed, the bulk water totalization will be combined with the RGA residual water detection (mass spectrometry) to determine total water removed from the system.

Although described in this section, the three primary bulk water removal and totalization tests will be performed at the start of the "full cycle" pristine fuel test (section 9.6.2), the damaged fuel test (section 9.6.6) and the mixed fuel test (section 9.6.10).

\subsubsection{Prerequisites}

1.0 RECORD observations in logbook.

2.0 BYPASS IXM. (CLOSE IXM isolation valves IXM-IV-P001 AND IXM-IV-P002 AND OPEN IXM-BPV-P001.)

\subsubsection{Bulk Water Removal with Clean and Empty MCO at Ambient Temperature Instructions}

NOTE: DO NOT operate TWS for this test and 9.5 .3

1.0 ADD 150 gallons to the MCO by following the steps in section 9.1.10 for MCO Water Fill. 
HP 150 gallons added (requircd only once)

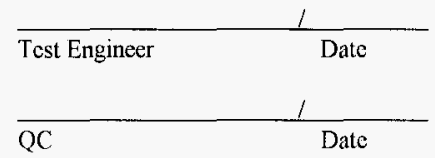

2.0 VENT the MCO by following the steps of section 9.1.11. Visually INSPECT the water depth in the MCO using the boroscope. RECORD approximate water level in logbook. REMOVE borscope and CLOSE inspection port.

3.0 START Bulk water drain sequence or manually DRAIN MCO by using steps outlined in section 9. 1.1. RECORD observations of PWC flow and pressure during the drain sequence.

4.) After "break through," ALLOW 10 minutes for MCO to drain into MCO bottom.

5.0 EVACUATE the remaining water from the MCO. VENT the MCO by following section 9.1.11. Visually INSPECT the MCO using the boroscope.

6.0 OBSERVE and RECORD where remaining water is located in logbook.

7.0 REMOVE borscope and CLOSE inspection port

8.) RECORD the WRT level

9.0 SLBTRACT the final WRT level reading from the initial WRT level reading to obtain the water total left inside the MCO by using the test log book.

10.0 DRY the inside of the MCO until it is visually dry. REPEAT steps 1 through 9 one additional time and record findings in the logbook.

\subsubsection{Clean MCO with Basket and Mock Fuel (all configurations)}

1.0 REPEAT section for a clcan MCO bulk water removal (section 9.1.1) utilizing a clean, dry MCO, baskct, and mock fuel. RECORD initial readings and temperatures in the logbook.

2.0 REPEAT step I for differing surface drain down times such as: 10,20, and 30 minutes. RECORD values in logbook.

MCO Bulk Water Removal and Totalization completed.

$\overline{\text { Test Engineer }}-\frac{1}{\text { Date }}$

\subsubsection{Bulk Water Removal at $50^{\circ} \mathrm{C}$}

1.0 START temepred water heating using computer sequence or section 9.1.3.

2.0 ADD 150 gallons of heated water $\left(50^{\circ} \mathrm{C} \pm 2^{\circ} \mathrm{C}\right)$ to the $\mathrm{MCO}$.

3.0 ALLOW MCO temperature to stablize within $\pm 2^{\circ} \mathrm{C}$ 
4.0 REPEAT Section 9.5.2 steps 3.0 through 6.0.

Witness Point

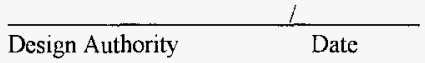

5.0 REPEAT steps 1.0 through 4.0 as directed by test engineer.

Heated Bulk Water Removal and Totalization completed.

Test Engineer

\subsection{FUEL DRYING}

\subsubsection{Heat Up Cycle Determination}

This test measures the time required to heat the $\mathrm{MCO}$ (containing the pristine fuel package) from a "cold" water fill to $50^{\circ} \mathrm{C}$. The MCO shall be filled with water to the filter guard plate on the bottom of the MCO shicld plug during this test.

Although described in this section, three primary heat up tests will be performed at the start of the "full cycle" pristine fuel test (section 9.6.2), the damaged fuel test (section 9.6.6) and the mixed fuel test (section 9.6.10). The remainder of the heating cycles for a given fuel configuration shall be shortened by adding warm water to the MCO between tests.

This activity will demonstrate the mock fucl and MCO heat-up characteristics, uniformity and duration, using a conservative MCO with no internal heat generation. The test will begin when the MCO and mock fuel temperatures are at established $\mathrm{K}$-Basin water temperature and end when all the test articles are at the tempered water system set point temperature

\subsubsection{Prerequisites}

1.) LOAD fucl in the MCO.

HP Fuel Configuration: $\sqcup$ Pristene fucl $\quad \sqsupset$ Damaged fuel $\quad \square$ Mixed fuel

Fucl configuration for fucl heating

\begin{tabular}{lc}
\hline Test Engineer & Date \\
\hline QC & Datc
\end{tabular}

2.0 FILL the MCO with water to the filter guard plate on the bottom of the MCO shield plug

HP MCO water level at shield plug bottom

\begin{tabular}{ll}
\hline Test Engineer & $\frac{1}{\text { Date }}$ \\
\hline $\mathrm{QC}$ & Date
\end{tabular}


3.0 RECORD obscrvations in the Logbook.

\subsubsection{Tempered Water Heatup}

1.0 FOLLOW steps in section 9.1.3.

\subsubsection{Pristine Fuel Normal Drying Sequence (Full 8-4-4 Cycle)}

A sequence of drying tests will be performed with the MCO in the pristine fueled configuration (as previously defined). This particular test utilizes the complete CVD process starting with the Full Cycle 8-4-4 sequence operation, followed by the Post Dry Operation described in section 9.1.9. This MCO fuel mockup represents the best case drying conditions that can be expected for a fucl loaded $\mathrm{MCO}$, and thus is described in Appendix A as the "most conservative best case MCO".

\subsubsection{Prerequisites}

1.0 LOAD MCO with Pristine Fuel

HP Pristene fuel loaded

\begin{tabular}{lc}
\hline Test Engineer & Date \\
\hline QC & Date
\end{tabular}

2.0 TWS is operating at stable $50^{\circ} \mathrm{C}$

30 $\mathrm{SCHe}$ is operational.

4.0 FILL MCO w/water to shield plug bottom.

HP MCO water level at shicld plug bottom

\begin{tabular}{l|}
\hline Test Engineer \\
\hline QC
\end{tabular}

5.0 RECORD Obscrvation in Logbook

\subsubsection{Instructions}

1.0 FOLLOW steps in section 9.1.7 for 8-4-4 sequence or using the computer controlled sequencing, if available.

\subsubsection{Damaged Fuel Drying Sequence (Full 8-4-4 Cycle)}

The next sequence of drying tests will be performed with the MCO in the damaged fucl configuration. This fucl mockup represents a difficult fuel condition for MCO drying, and thus is described in Appendix A 
as the "difficult drying case MCO". For this particular test, the MCO starts full of water and includes the Full Cycle 8-4-4 sequence operation, followed by the Post Dry Operation. The data acquired will aid in model validation and the system verification analysis under difficult drying conditions for the MCO fuel.

\subsubsection{Prerequisites}

1.0 LOAD MCO with damaged fuel.

HP Damaged Fuel Loaded

\begin{tabular}{lc} 
& $\frac{1}{\text { Test Engineer }}$ \\
& Date \\
\hline QC & Date
\end{tabular}

2.0 TWS is operating at stable $50^{\circ} \mathrm{C}$.

3.0 SCHe is operational.

4.0 FILL MCO with water to shicld plug bottom

HP MCO water level at shield plug bottom

\begin{tabular}{lc}
\hline Test Engineer & Datc \\
\hline $\mathrm{QC}$ & $\frac{1}{\text { Date }}$
\end{tabular}

5.0 RECORD Observation in Logbook

\subsubsection{Instructions}

1.0 FOLLOW the steps for the 8-4-4 cycle in section 9.1.7 or use the MCS resident programming UNTIL DRY.

2.) FOLLOW the sequence of operations for the Post Dry Operation section 9.1.8

\subsubsection{Mixed Fuel (Nominal) Normal Drying Sequence (Full 8-4-4 Cycle)}

This sequence of drying tests will be performed with the $\mathrm{MCO}$ in the mixed fucl configuration. This MCO fuel mockup represents an intermediate fuel condition between best and worst case drying conditions, which is probably more protolypic of authentic conditions, and is thus represented as the "nominal case" in Appendix A, Table A-2. This particular test starts with the MCO full of water and includes the Full Cycle 84-4 sequence operation, followed by the Post Dry Operation. The data acquired will aid in model validation and the system verification analysis under "nominal" case MCO fuel conditions

\subsubsection{Prerequisites}

1.0 LOAD MCO with mixed fucl. 
HP Mixed fuel loaded

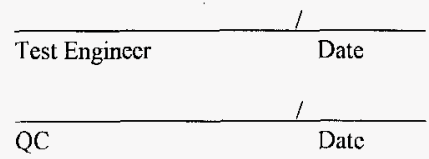

2.0 TWS is operating at stable $50^{\circ} \mathrm{C}$.

3.0 SCHe is operational

4.0 FILL MCO with water to shield plug bottom

HP MCO water level at shicld plug bottom

\begin{tabular}{lc}
\hline Test Engineer & Date \\
\hline QC & Date
\end{tabular}

5.0 RECORD Observation in Logbook

\subsubsection{Instructions}

1.0 FOLLOW the sequence of operations for the 8-4-4 drying cycle in section 9.1 .7 or the resident MCS programming UNTIL DRY.

2.0 FOLLOW the sequence of operations for the Post Dry Operation in section 9.1.8.

HP Design Authority Hold Point for data reduction and verification.

$\frac{1}{\text { Design Authority } \quad \text { Date }}$

\subsubsection{Mixed Fuel (Nominal) Condenser/Purge 1 SCFM Cycle Drying}

This test uscs only the vacuum pump, condenser and helium purge operations (but at l scfm), excluding the helium recycle operation, to accomplish drying of the MCO with mixed fuel. Since the Post Dry Operation is excluded, this will be a shorter test; the data acquired will help evaluate the role of the helium recycle operation in MCO drying.

\subsubsection{Prerequisites}

1.0 LOAD MCO with mixed fuel.

HP Mixed fucl loaded

\begin{tabular}{lc}
\hline Test Engineer & Date \\
\hline $\mathrm{QC}$ & Date
\end{tabular}

2.0 TWS is operating at stable $50^{\circ} \mathrm{C}$. 
3.0 SCHe is operational.

4.0 FILL MCO with water to shield plug bottom.

HP MCO water level at shield plug bottom

\begin{tabular}{lc} 
& \multicolumn{1}{c}{ Date } \\
\hline Test Engineer & $/$ \\
\hline QC & Date
\end{tabular}

5.0 RECORD observations in Logbook

\subsubsection{Instructions}

1.0 FOLLOW the sequence of operations in section 9.1.5 for vacuum with condendor at $1 \mathrm{scfm}$ (set FIC 1219).

\subsubsection{Mixed Fuel (35 ${ }^{\circ} \mathrm{C}$ Bath) 8-4-4 Cycle Drying}

This test shall be performed using the Full Cycle 8-4-4 sequence drying procedure; however, the bath is held at a reduced temperature of $35^{\circ} \mathrm{C}$, and the Post Dry Operation is not performed in order to shorten the testing time.

\subsubsection{Prerequisites}

1.0 LOAD MCO with mixed fuel

HP Mixed fuel loaded

\begin{tabular}{lc}
\hline Test Engineer & $\frac{1}{\text { Date }}$ \\
\hline QC & Date
\end{tabular}

2.0 TWS is operating at stable $50^{\circ} \mathrm{C}$.

3.0 SCHc is operational.

4.0 FILL MCO with water to shield plug bottom.

HP MCO water level at shield plug bottom

\begin{tabular}{lc} 
& \multicolumn{1}{c}{ Date } \\
\hline Test Engineer & Date
\end{tabular}

5.0 RECORD observation in logbook

\subsubsection{Instructions}


1.0 FOLLOW the 8-4-4 full cycle sequence of operations section 9.1.7 - set bath at $35^{\circ} \mathrm{C}$ - SET Tempered Water Heater TW-HTR-3211 to $35^{\circ} \mathrm{C}$.

\subsubsection{Mixed Fuel Vacuum Only with Purge 1.6 SCFM Cycle Drying}

This test uscs only the vacuum pump and helium purge operations ( $1.6 \mathrm{scfm}$ ), excluding the helium recycle operation at $10 \mathrm{scfm}$, to accomplish drying of the MCO. Since the Post Dry Operation is excluded, this will be a shorter test; the data acquired will help cvaluate the role of the helium recycle operation in $\mathrm{MCO}$ drying.

\subsubsection{Prerequisites}

1.0 LOAD MCO with mixed fuel

HP Mixed Fuel Loaded

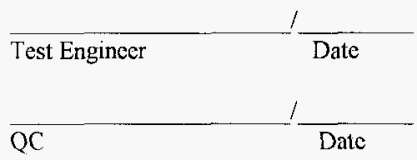

2.0 TWS is operating at stable $50^{\circ} \mathrm{C}$.

3.0 SCHe is operational.

4.0 FILL MCO with water to shield plug bottom

HP MCO water level at shicld plug bottom

\begin{tabular}{lc}
\hline Test Engineer & $\frac{1}{\text { Date }}$ \\
\hline QC & Date
\end{tabular}

5.0 RECORD Observation in Logbook

\subsubsection{Instructions}

1.0 FOLLOW the sequence of operations for Vacuum Drying with condensor section 9.1.6 with the purge set at $1.6 \mathrm{scfm}$.

\subsubsection{Mixed Fuel $\left(10^{\circ} \mathrm{C}\right.$ Condenser) 8-4-4 Cycle Drying}

This test shall be performed using a Full Cycle 8-4-4 sequence drying procedure (with a normal bath temperature of $50^{\circ} \mathrm{C}$ ), but the condenser temperature shall be increased to $10^{\circ} \mathrm{C}$. Again, the Post Dry Operation is excluded in order to shorten testing time 


\subsubsection{Prerequisites}

1.0 LOAD MCO with mixed fuel

HP Mixed fucl loaded

\begin{tabular}{lc}
\hline Test Engineer & Date \\
\hline QC & Date
\end{tabular}

2.0 TWS is operating at stable $50^{\circ} \mathrm{C}$.

3.0 SCHe is operational.

4.0 FILL MCO with water to shield plug bottom.

HP MCO watcr level at shield plug bottom

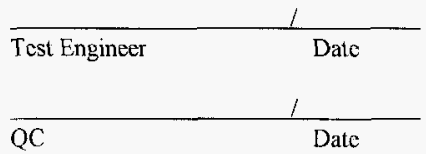

5.0 RECORD Observation in Logbook

\subsubsection{Instructions}

1.0 FOLLOW the sequence of operations for the 8-4-4 drying sequence, section 9.1.7 with the condensor temperature set at $10^{\circ} \mathrm{C}$ UNTIL DRY.

\subsubsection{Mixed Fuel Helium Recycle or Purge Only Drying}

This test uscs only the helium recycle ( $10 \mathrm{scfm})$ process to perform drying; the time required to perform this function will be the primary data obtained, and will be used to refine performance modeling with respect to other cycles.

\subsubsection{Prerequisites}

1.0 LOAD MCO with mixed fucl.

HP Mixed Fuel Loaded

\begin{tabular}{lc}
\hline Test Engineer & $\frac{1}{\text { Date }}$ \\
\hline QC & Date
\end{tabular}

2.0 TWS is opcrating at stable $50^{\circ} \mathrm{C}$.

3.0 SCHc is operational. 
HNF-2402

Rev. 0

4.0 FILL MCO with water to shield plug bottom.

HP MCO water level at shield plug bottom

\begin{tabular}{lc} 
& \multicolumn{1}{c}{ Datc } \\
\hline Test Engineer & $/$ \\
\hline QC & Datc
\end{tabular}

5.0 RECORD Observation in Logbook.

\subsubsection{Instructions}

1.0 FOLLOW the sequence of operations for hclium purge in section 9.1 .4 with flow set at $10 \mathrm{scfm}$.

\subsubsection{Mixed Fuel (Nominal) Normal Drying Revised Sequence (Full 8-4-4 Cycle)}

This sequence of drying tests will be performed with the MCO in the mixed fuel configuration. This MCO fuel mockup represents an intermediate fucl condition between best and worst case drying conditions, which is probably more prototypic of authentic conditions, and is thus represented as the "nominal case" in Appendix A. Table A-2. This particular test starts with the MCO full of water and includes the Full Cycle 84-4 sequence operation, followed by the Post Dry Operation. The data acquired will aid in model validation and the system verification analysis under "nominal" case MCO fuel conditions.

\subsubsection{Prerequisites}

1.0 LOAD MCO with mixed fuel.

HP Mixed fuel loaded

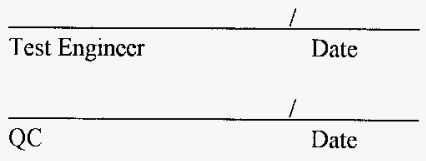

2.0 TWS is operating at stable $50^{\circ} \mathrm{C}$.

3.0 SCHe is operational.

4.0 FILL MCO with water to shicld plug bottom.

HP MCO water level at shicld plug bottom

\begin{tabular}{ll} 
& $\frac{1}{\text { Test Engincer }}$ \\
\hline DC & Date \\
\hline
\end{tabular}

5.0 RECORD Obscrvation in Logbook

\subsubsection{Instructions}


1.0 FOLLOW the revised sequence of operations for the 8-4-4 drying cycle in using the automated sequencing resident in the MCS UNTIL DRY.

\subsection{CASK PURGING}

This test will qualitatively determine the length of purge time to meet the MCO handling criteria established at the CSB. Temporary dew point sensors may be placed on the cask outlet to determine purging duration and cask dryness (defined in HNF-SD-SNF-OCD-001).

\subsubsection{Prerequisites}

1.0 INSTALL and ISOLATE dew point sensor probe into the cask lower port connector spool piece for draining the cask near quick disconnect PWC-QD-2020

\subsubsection{Instructions}

1.0 FILL cask annulus with water (if not completed in advance)

20 REMOVE cask lower port processing quick disconnect (if not completed in advance).

3.0 INSTALL cask drain connection with quick disconnect PWC-QD-2020

4.0 ENSURE MCO isolation. CLOSE GOV 1209, 1202 and 1230.

5.0 FOLLOW sequence for Bulk Water Draining in section 9.1.1.

6.0 Manually OPEN PWC-V-2048 AND GOV 1215.

7.0 Once break through has occurred, OPEN dew point sensor isolation valves AND CONTINUE purging for 30 minutes. RECORD dew point reading at in five minute intervals in logbook throughout purging interval.

8.0 CLOSE PWC-V-2048 AND GOV 1215. STOP PWC system pump PWC-P-4036.

90 REPEAT test as directed by test director.

\subsection{SPECIAL TOOLS AND SPECIAL FUNCTIONS}

\subsubsection{Special Tools}

Special tools such the $\mathrm{MCO}$ /process connectors and the cask tempered water connections shall be tested as part of the first article testing. The tool performance functions shall be noted in the test log book if any unusual circumstance (as defined by the test director and design authority) occur during operation of the tool.

Special tools such as: cask pressurization and relief tool; MCO valve closure tool prior to process connector installation: VPS leak check chamber; cask connectors; and additional special tools may be tested as part of the first article testing depending on tool fabrication schedules and also first article testing 
schedule and budget.

Procedures will be supplicd as tools become available for testing. Record tooling and procedurc \#'s in $\log$ book and record procedure exceptions.

\subsubsection{Special Functions}

Special functions of the VPS/TWS, PWC, Hood, and SCHe skids may be performed given first article testing schedule and budget or test review board approval. These features include: tempered water heat up to $85^{\circ} \mathrm{C}$; SC Helium purge line examination for water ingress and blow out; and PWC prefiltration with an IXM

Procedures will be supplicd and enter as exceptions to this procedure as the procedures become available. Record all findings in log book and record additional procedure exceptions.

\subsection{SAFETY CLASS ISOLATABLE MAIN LINE BREAK}

A temporary valve will be installed in the main line (within isolation valve control) allowing a simulation of a main line break that can be controlled by the MCO isolation valves. The objective of this test is to demonstrate instrument detection of the break and a safe shut down of the system (by reducing air concentration to acceptable limits) after a main linc break. Parameters to be measured include the timc required to backfill the $\mathrm{MCO}$ with helium and to isolate it. Also, the partial pressure of air ingress into the $\mathrm{MCO}$ will be measured

\subsubsection{Prerequisites}

1.0 RGA Data acquisition system is on-line and opcrational

2.0 ATTACH (as indicated) $1 / 4$ " flex tubing to process connector SCHe injection port opposite the main line break. FIELD ROUTE tubing to RGA (AE 2213). CONNECT tubing to the RGA calibration port. CLOSE sample valve SMP-V-2029. OPEN sample valve SMP-V-2032. ALLOW for system to reach a residual gas baseline. INJECT a small amount Helium into the other $\mathrm{SCHe}$ port on the same process connector as the 1/4" RGA flex tubing is connected. CHECK for system response time and RECORD the time lapse until the RGA detects the Helium. Consult test director and test engineer as necessary.

3.0 Safety Class Helium Injection system is VALVED IN and OPERATIONAL.

4.0 RECORD observations in logbook.

\subsubsection{HE.PA Filter Port Main Line Break Instructions}

1.0 ATTACH RGA flex tubing to the dip tube port process connector.

2.0 With an EMPTY MCO, OPERATE a vacuum with condenser sequence manually as described in section 9. 1.7.1 or automatically. ALLOW system come to a base pressure.

3.0 OPEN MLB-V-002. RECORD the clapsed time when the MLB-V-002 is opened until the SC 
Helium system begins injection and GOV isolation. RECORD the elapse time from isolation to the RGA detection of Helium and the clapsed time to remove the air present in the MCO below 20 percent (Flammability Characteristics of Combustible Gases and Vapors, Report 627, Burcau of Mincs)

\subsubsection{Diptube Port Main Line Break Instructions}

1.0 ATTACH RGA flex tubing to the HEPA filter port process connector.

2.0 With an EMPTY MCO, OPERATE a vacuum with condenser sequence manually as described in section 9.1.7.1 or automatically. ALLOW system come to a base pressurc.

3.0 OPEN MLB-V-004. RECORD the elapsed time when the MLB-V-004 is opened until the SC Helium system begins injection and GOV isolation. RECORD the clapse time from isolation to the RGA detection of Helium and the elapsed time to remove the air present in the MCO below 20 percent ("Flammability Characteristics of Combustible Gases and Vapors" Report 627 Bureau of Mincs).

\subsection{CLOSE MLB-V-004.}

\subsection{SAFETY CLASS NON-ISOLATABLE MAIN LINE BREAK}

A temporary valve will be installed in the main line (on the MCO side of the isolation valves outside of isolation valve control), again, allowing a simulation of a line break; however, without isolation valve control. The objective of this test is to demonstrate instrument detection of the break and a safe shut down of the system (by reducing air concentration to acceptable limits) under these conditions. Parameters to be measured include the time required to backfill the $\mathrm{MCO}$ with helium and to isolate it. Also, the partial pressure of air ingress into the $\mathrm{MCO}$ will be measured.

\subsubsection{Prerequisites}

1.0 RCiA Data acquisition system is on-line and operational

2.0 ATTACH (as indicated) 1/4" flex tubing to process connector SCHe injection port opposite the main line brcak. FIELD ROUTE tubing to RGA (AE 2213). CONNECT tubing to the RGA calibration port. CLOSE sample valve SMP-V-2029. OPEN sample valve SMP-V-2032. ALLOW for system to reach a residual gas baseline. INJECT a small amount Helium into the other SCHe port on the same process connector as the $1 / 4$ " RGA flex tubing is connected. CHECK for system response tume and RECORD the time lapse until the RGA detects the Helium. Consult test director and test engineer as necessary.

3.0 Salety Class Helium Injection system is valved in and operational.

4.0 RECORD observations in logbook 
HNF-2402

Rev. 0

\subsubsection{HEPA Filter Port Main Line Break Instructions}

1.0 ATTACH RGA flex tubing to the dip tube port process connector.

2.0 With an EMPTY MCO, OPERATE a vacuum with condenser sequence manually as described in section 9.1.7.1 or automatically. ALLOW system come to a base pressure.

3.0 OPEN MLB-V-001. RECORD the elapsed time when the MLB-V-001 is opened until the SC Helium system begins injection and GOV isolation. RECORD the elapse time from isolation to the RGA detection of Helium and the elapsed time to remove the air present in the MCO BELOW 20 percent (Flammability Characteristics of Combustible Gases and Vapors, Report 627, Bureau of Mines).

4.0 CLOSE MLB-V-00I

\subsubsection{Diptube Port Main Line Break Instructions}

1.0 ATTACH RGA flex tubing to the HEPA filter port process connector.

2.0 With an EMPTY MCO, OPERATE a vacuum with condenser sequence manually as described in section 9.1 .5 or automatically. ALLOW system come to a base pressure

3.0 OPEN MLB-V-003. RECORD the elapsed time when the MLB-V-003 is opened until the SC Hclium systcm begins injection and GOV isolation. RECORD the clapse time from isolation to the RGA detection of Helium and the elapsed time to rcmove the air present in the MCO BELOW 20 percent (Flammability Characteristics of Combustible Gases and Vapors, Report 627, Bureau of Mines).

4.0 CLOSE MLB-V-003.

\subsection{SLUDGE DRYING}

A known quantity of sludge simulant shall be placed into the CVD Proof-of-Concept Testing Apparatus (rather than the MCO) in the presence of the pristine fuel mockup, together with a quantity (to-bedetermined) of water. Then the Apparatus shall be heated to temperature (nominally $50^{\circ} \mathrm{C}$ ), and evacuatcd and dricd using the proof of concept system vacuum pump with the condenser operating at $1{ }^{\circ} \mathrm{C}$.

The purpose of this testing is to provide an understanding of sludge drying time utilizing a simulated sludge that will be similar to what is expected to form during the heating cycle of the CVD process. The tests may be conducted in parallel with the first article testing of the VPS/TWS. The tests shall be conducted in the CVD proof of concept test apparatus, illustrated in Figure 3 (Appendix J). Utilizing this test apparatus will allow visual indication of the sludge drying process and casy access to the sludge specimens during any stage of the drying process. 
HNF-2402

Rev. 0

\subsubsection{Prerequisites}

Assure the test apparatus is fabricated in accordance with the test director and calibration records are supplied and located in Appendix F . Refer to Figure 3 Appendix J for general set-up assistance. Verify proper operation of instruments and data acquisition system (DAS) operation.

\subsubsection{Instructions}

$\overline{\text { Test Engineer }} \frac{1}{\text { Date }}$

1.0 This procedure will be added by an ECN as required. 


\section{APPENDIX A \\ TENTATIVE CVD PROOF OF PERFORMANCE TESTING SCHEDULE}

The primary, "Phase I" CVD Proof of Performance tests are divided into two categorics, described as "Preliminary" and "First Article" tests. The Preliminary CVD proof of performance tests are summarized in Table A-1. whereas the First Article tests are summarized in Table A-2. Although an order of testing is implied in these two tables, testing order may be modified as described in section 5.3.2. The tests described in these two tables provide proof of performance data that will be used in process model validation and CVD system verification studies. These tests involve various permutations of fucl configurations and process hardware operations.

In addition to the high priority Phase I tests described in Tables A-1 and A-2, a lower priority set of "Phase II" tests arc identified below as follows:

- Damaged Fuel Drying - Helium Recycle Only

- Mixed Fucl Drying - Helium Recycle Only

- Duplication of Phase I Tests (to demonstrate repeatability of results)

- Runaway Reaction Study (using heated clements to simulate fuel thermal effects)

- Pressurc Relcase During Cask Lid Removal

Phase Il tests will be performed only if there is sufficient funds and time, and are not described in detail here. 
HNF-2402

Rev. 0

Table A-1 Preliminary Test Descriptions and Prioritics Array

(I hese tests may be removed or other tests may be substituted from the testing program per change control previously identified in this document

\begin{tabular}{|c|c|c|c|c|c|c|c|c|c|c|}
\hline $\begin{array}{c}\text { Test } \\
\#\end{array}$ & Description of Test & Test Objectives & $\begin{array}{c}\text { Bath } \\
\text { Temp } \\
{ }^{\circ} \mathrm{C}\end{array}$ & $\begin{array}{l}\text { Cond } \\
\text { Temp } \\
{ }^{\circ} \mathrm{C}\end{array}$ & $\begin{array}{l}\text { Expected } \\
\text { Test } \\
\text { Duration } \\
\text { (days) } \\
\end{array}$ & Timing & Priority & $\begin{array}{l}\text { Design } \\
\text { Impacts } \\
(\mathbf{Y} / \mathbf{N})\end{array}$ & $\begin{array}{l}\text { Test Articles } \\
\text { Inside MCO }\end{array}$ & No-Test Consequences \\
\hline 1 & $\begin{array}{l}\text { Fuel Basket luel Water Retention } \\
\text { Test }\end{array}$ & $\begin{array}{l}\text { Determine water retention in the three mock } \\
\text { configurations (Pristine, Damaged and } \\
\text { Mixed) }\end{array}$ & Amb. & Amb. & 2 & 1 & 2 & $\mathrm{~N}$ & Clean filter & $\begin{array}{l}\text { Needed to quantify water removal } \\
\text { effectiveness in other test operations }\end{array}$ \\
\hline 2 & $\begin{array}{l}\text { Process Connector and System } \\
\text { Flushing Efficiency Test }\end{array}$ & $\begin{array}{l}\text { Establishes if siudge will remain in process } \\
\text { connector piping and valves after rinsing - } \\
\text { associated radiological hazard }\end{array}$ & Amb. & Amb. & 1 & 2 & 2 & Y & NA & Potentially unacceptable dose rates. \\
\hline 3 & Water Ingress & $\begin{array}{l}\text { Verify that water didn't leak into MCO } \\
\text { during flushing efficiency test }\end{array}$ & Amb & Amb. & 1 & 3 & 2 & $\mathrm{Y}$ & Clean filter & Potential facility contamination risks \\
\hline 4 & Sludge Drying & Establish sludge simulant drying times & 50 & 1 & 2 & 4 & 3 & $\mathrm{Y}$ & $\begin{array}{l}\text { Clean filter } \\
\text { Pristine fuel }\end{array}$ & $\begin{array}{l}\text { Potential inability to dry sludge with } \\
\text { required times. }\end{array}$ \\
\hline 5 & Hood Ventilation & $\begin{array}{l}\text { Verify process hood air flow integrity - no } \\
\text { eddy currents to contaminate breathable air } \\
\text { space }\end{array}$ & NA & NA & 1 & 5 & 2 & $\mathrm{Y}$ & NA & $\begin{array}{l}\text { Potentially unacceptable personnel } \\
\text { dose rate levels. }\end{array}$ \\
\hline 6 & Seal Ring Leak Checking & Verify leak rates of MCO to seal rings seals & NA & NA & 1 & 6 & 2 & $\mathrm{Y}$ & $\begin{array}{l}\text { Seal Ring, } \\
\text { Cask, MCO, } \\
\text { Shield plug }\end{array}$ & $\begin{array}{l}\text { Potential inability to leak check the } \\
\text { main MCO seal after the CVD } \\
\text { process }\end{array}$ \\
\hline 7 & MCS Setup and Testing & $\begin{array}{l}\text { Debug the software hardware interfaces and } \\
\text { demonstrate adequate system control to } \\
\text { perform first article testing }\end{array}$ & NA & NA & 3 & 7 & 1 & $\mathrm{Y}$ & $\begin{array}{l}\text { Clean filter } \\
\text { Pristine fuel }\end{array}$ & $\begin{array}{l}\text { Delays and expensive manual } \\
\text { operation of system during testing. }\end{array}$ \\
\hline
\end{tabular}


HNF-2402

Rev: 0

Table A-2 First Article Test Descriptions and Priorities Array

(These tests may be removed or other tests may be substituted from the testing program per change control previously identified in this document)

\begin{tabular}{|c|c|c|c|c|c|c|c|c|c|c|}
\hline $\begin{array}{c}\text { Test } \\
\#\end{array}$ & Description of Test & Test Objectives & $\begin{array}{c}\text { Bath } \\
\text { Temp } \\
{ }^{\circ} \mathbf{C}\end{array}$ & $\begin{array}{c}\text { Cond } \\
\text { Temp } \\
{ }^{\circ} \mathrm{C}\end{array}$ & $\begin{array}{l}\text { Expected } \\
\text { Test } \\
\text { Duration } \\
\text { (days) }\end{array}$ & Timing & Priority & $\begin{array}{l}\text { Design } \\
\text { Impacts } \\
(\mathbf{Y} / \mathbf{N})\end{array}$ & $\begin{array}{l}\text { Test Articles } \\
\text { Inside MCO }\end{array}$ & No-Test Consequences \\
\hline ] & Baseline Establishment & $\begin{array}{l}\text { Establishes sustem leak tightness, off } \\
\text { gassing, dryness, preliminary heatup times } \\
\text { and overali system verification }\end{array}$ & 50 & 1 & 2 & 1 & 1 & $\mathrm{Y}$ & Clean filter & MUS1 Test to verify system integrity. \\
\hline 2 & Upset Conditions lest & $\begin{array}{l}\text { Demonstrate safe system shutdown under } \\
\text { loss of electrical power, and loss of } \\
\text { computer }\end{array}$ & Amb. & Amb. & 2 & 2 & 1 & $\mathrm{Y}$ & Clean filter & $\begin{array}{l}\text { Operational Safety Compromised at } \\
\text { CVDF. }\end{array}$ \\
\hline 3 & 32 L iter Residual Water Drying Test & $\begin{array}{l}\text { Establishes system baselines and system } \\
\text { verification for condenser operations }\end{array}$ & 50 & 1 & 1 & 3 & 1 & $\mathrm{Y}$ & Clean filter & $\begin{array}{l}\text { Inability to distinguish between basic } \\
\text { MCO and fuel fuel basket effects. }\end{array}$ \\
\hline 4 & Pristine Fuel Water Retention & $\begin{array}{l}\text { Determine water quantity left in pristine } \\
\text { fueied MCO after buik water removed }\end{array}$ & Amb. & Amb. & 1 & 12 & 1 & $\mathrm{~N}$ & $\begin{array}{l}\text { Clean filter } \\
\text { Pristine fuel }\end{array}$ & $\begin{array}{l}\text { Unabic to compare removal rate data } \\
\text { between different fuel config. }\end{array}$ \\
\hline 5 & Pristine Fuel Heat Ujp Cycle & Establish system Heat Up cycle times & 50 & 1 & 1 & 12 & 1 & Y & $\begin{array}{l}\text { Clean filter } \\
\text { Pristine fuel }\end{array}$ & $\begin{array}{l}\text { Lost time due to heating inefficiency } \\
\text { for each CVD test. }\end{array}$ \\
\hline 6 & $\begin{array}{l}\text { Pristine Fuel Drying } \\
\text { (Full Cycle } 8-4-4 \text {; includes Post Dry } \\
\text { Operation after Full Cycle } \\
\text { completed) }\end{array}$ & $\begin{array}{l}\text { Establishes drying times and process } \\
\text { parameters for most conservative best case } \\
\text { MCO using complete system capabilities. } \\
\text { Process model validation and system } \\
\text { verification. (Note: Full Cycle =- vacuum } \\
\text { pump \& condenser \& helium purge }\{1.6 \\
\text { scfm\} for } 8 \text { hrs, helium recycle }\{10 \mathrm{scfm}\} \\
\text { for } 4 \text { hrs, followed by vacuum pump for } 4 \\
\text { hrs.) }\end{array}$ & 50 & 1 & 2 & 12 & 1 & $\mathrm{Y}$ & $\begin{array}{l}\text { Clean filter } \\
\text { Pristine fuel }\end{array}$ & $\begin{array}{l}\text { Inability to establish effects of } \\
\text { different fuel configurations on } \\
\text { system performance. }\end{array}$ \\
\hline 7 & Main Line Break I Upset & $\begin{array}{l}\text { Establish the effects of a main line break } \\
\text { inside isolation valve control, with respect to } \\
\text { I \& C control and safety performance }\end{array}$ & 50 & 1 & 1 & 5 & 1 & $Y$ & $\begin{array}{l}\text { Clean filter } \\
\text { Pristine fuel }\end{array}$ & Potentially unsafe system. \\
\hline 8 & Main Line Break II Upset & $\begin{array}{l}\text { Establish the effects of a main line break } \\
\text { between the isolation valves and } \mathrm{MCO} \text { (no } \\
\text { isolation valve control) with respect to I \& } \mathrm{C} \\
\text { control and safety performance }\end{array}$ & 50 & 1 & 1 & 6 & 1 & $\mathrm{Y}$ & $\begin{array}{l}\text { Clean filter } \\
\text { Pristine fuel }\end{array}$ & Potentially unsafe systern \\
\hline 9 & Damaged Fuel Water Retention & $\begin{array}{l}\text { Determine water quantity left in damaged } \\
\text { fueled MCO after bulk water removed. }\end{array}$ & Amb & Amb. & 1 & 13 & 1 & $\mathrm{~N}$ & $\begin{array}{l}\text { Clean filter } \\
\text { Damaged fuel }\end{array}$ & $\begin{array}{l}\text { Unable to compare removal rate data } \\
\text { between different fuel config. }\end{array}$ \\
\hline
\end{tabular}


HNF-2402

Rev: 0

Table A-2 First Article Test Descriptions and Priorities Array

(These tests may be removed or other tests may be substituted from the testing program per change control previously identified in this document)

\begin{tabular}{|c|c|c|c|c|c|c|c|c|c|c|}
\hline $\begin{array}{c}\text { Test } \\
\#\end{array}$ & Description of Test & Test Objectives & $\begin{array}{c}\text { Bath } \\
\text { Temp } \\
{ }^{\circ} \mathrm{C}\end{array}$ & $\begin{array}{l}\text { Cond } \\
\text { Temp } \\
{ }^{\circ} \mathrm{C}\end{array}$ & $\begin{array}{l}\text { Expected } \\
\text { Test } \\
\text { Duration } \\
\text { (days) }\end{array}$ & Timing & Priority & $\begin{array}{l}\text { Design } \\
\text { Impacts } \\
(\mathbf{Y} / \mathbf{N})\end{array}$ & $\begin{array}{l}\text { Test Articles } \\
\text { Inside MCO }\end{array}$ & No-Test Consequences \\
\hline 10 & Damaged 1-uel Heat Up Cicle & Establish system Heat Up cycle times & 50 & 1 & 1 & 13 & 3 & $\mathrm{~N}$ & $\begin{array}{l}\text { Clcan filter } \\
\text { Damaged fuel }\end{array}$ & $\begin{array}{l}\text { Lost time due to hcating inefficiency } \\
\text { for each CVD test. }\end{array}$ \\
\hline 11 & $\begin{array}{l}\text { Damaged Fuel Drying } \\
\text { (Fuil Cycle } 8-4-4 \text {; includes Post }] \text { ry } \\
\text { Operation after Full Cvcle } \\
\text { completed) }\end{array}$ & $\begin{array}{l}\text { Establishes drying times and process } \\
\text { parameter for difficult drying case MCO } \\
\text { using complete system capabilities. Process } \\
\text { model validation and system verification. }\end{array}$ & 50 & 1 & 2 & 13 & 1 & $\mathrm{Y}$ & $\begin{array}{l}\text { Clean filter } \\
\text { Damaged fuel }\end{array}$ & $\begin{array}{l}\text { Inability to establish effects of } \\
\text { different fuel configurations on } \\
\text { system performance. }\end{array}$ \\
\hline 12 & Mixed Fuel Water Retention & $\begin{array}{l}\text { Determine water quantity left in mixed } \\
\text { fueled MCO after bulk water removed. }\end{array}$ & Amb. & Amb & 1 & 4 & 1 & $\mathrm{~N}$ & $\begin{array}{l}\text { Clean filter } \\
\text { Mixed fuel }\end{array}$ & $\begin{array}{l}\text { Unable to compare removal rate data } \\
\text { between different fuel config. }\end{array}$ \\
\hline 13 & Mixed Fuel Heat Up Cycle & Establish system Heat Up cycle times & 50 & 1 & 1 & 4 & 3 & $\mathrm{~N}$ & $\begin{array}{l}\text { Clean filter } \\
\text { Mixed fuel }\end{array}$ & $\begin{array}{l}\text { Lost time due to heating inefficiency } \\
\text { for each CVD test. }\end{array}$ \\
\hline 14 & $\begin{array}{l}\text { Mixed Fuel Drying } \\
\text { (Full Cycle } 8-4-4 \text {; includes Post Dry } \\
\text { Operation after Full Cycle } \\
\text { completed) }\end{array}$ & $\begin{array}{l}\text { Establishes drying times and process } \\
\text { parameter for most conservative nominal } \\
\text { case MCO using complete system } \\
\text { capabilities. Process model validation and } \\
\text { system verification. }\end{array}$ & 50 & I & 2 & 4 & 1 & $\mathrm{~N}$ & $\begin{array}{l}\text { Clean filter } \\
\text { Mixed fuel }\end{array}$ & $\begin{array}{l}\text { Inability to establish effects of } \\
\text { different fucl configurations on } \\
\text { system performance. }\end{array}$ \\
\hline 15 & $\begin{array}{l}\text { Mixed Fuel Drying } \\
\text { (Continuous vacuum pump and } \\
\text { condenser operation with helium } \\
\text { purge at } 1 \text { scfm) }\end{array}$ & $\begin{array}{l}\text { Establishes drying times and process } \\
\text { parameter for most conservative nominal } \\
\text { case MCO using vacuum pump, condenser, } \\
\text { and helium purge ( }(a) \text { scfm) drying. } \\
\text { Process model validation and system } \\
\text { verification. }\end{array}$ & 50 & 1 & 2 & 7 & 2 & $\mathrm{~N}$ & $\begin{array}{l}\text { Clean filter } \\
\text { Mixed fuel }\end{array}$ & $\begin{array}{l}\text { Reduces data for model validation } \\
\text { with respect to vacuum pump } \\
\text { operation in worst case fue! } \\
\text { configuration. }\end{array}$ \\
\hline 16 & $\begin{array}{l}\text { Mixed Fuel Drying } \\
\text { (Continuous vacuum pump } \\
\text { operation with helium purge at } 1.6 \\
\text { scfm) }\end{array}$ & $\begin{array}{l}\text { Establishes drying times and process } \\
\text { parameter for difficult drying case MCO } \\
\text { using vacuum pump and helium purge } \\
\text { (@1.6 scfm) drying. Process model } \\
\text { validation and system verification. }\end{array}$ & 50 & l & 2 & 8 & 2 & $\mathrm{~N}$ & $\begin{array}{l}\text { Clean filter } \\
\text { Damaged fuel }\end{array}$ & $\begin{array}{l}\text { Reduces data for model validation } \\
\text { with respect to lower flow rate } \\
\text { condenser operation in difficult case } \\
\text { fuel configuration. }\end{array}$ \\
\hline 17 & $\begin{array}{l}\text { Mixed Fuel Drying } \\
\text { (Full Cycle 8-4-4, reduced bath } \\
\text { temperature) }\end{array}$ & $\begin{array}{l}\text { Establishes drying times and process } \\
\text { parameter for difficult drying case MCO } \\
\text { using reduced bath temperature. Process } \\
\text { model validation and system verification. }\end{array}$ & 35 & 1 & 2 & 9 & 2 & $\mathrm{~N}$ & $\begin{array}{l}\text { Clean filter } \\
\text { Damaged fuel }\end{array}$ & $\begin{array}{l}\text { Reduces data for model validation } \\
\text { with respect to bath temperature } \\
\text { effects in worst case fuel } \\
\text { configuration. }\end{array}$ \\
\hline
\end{tabular}




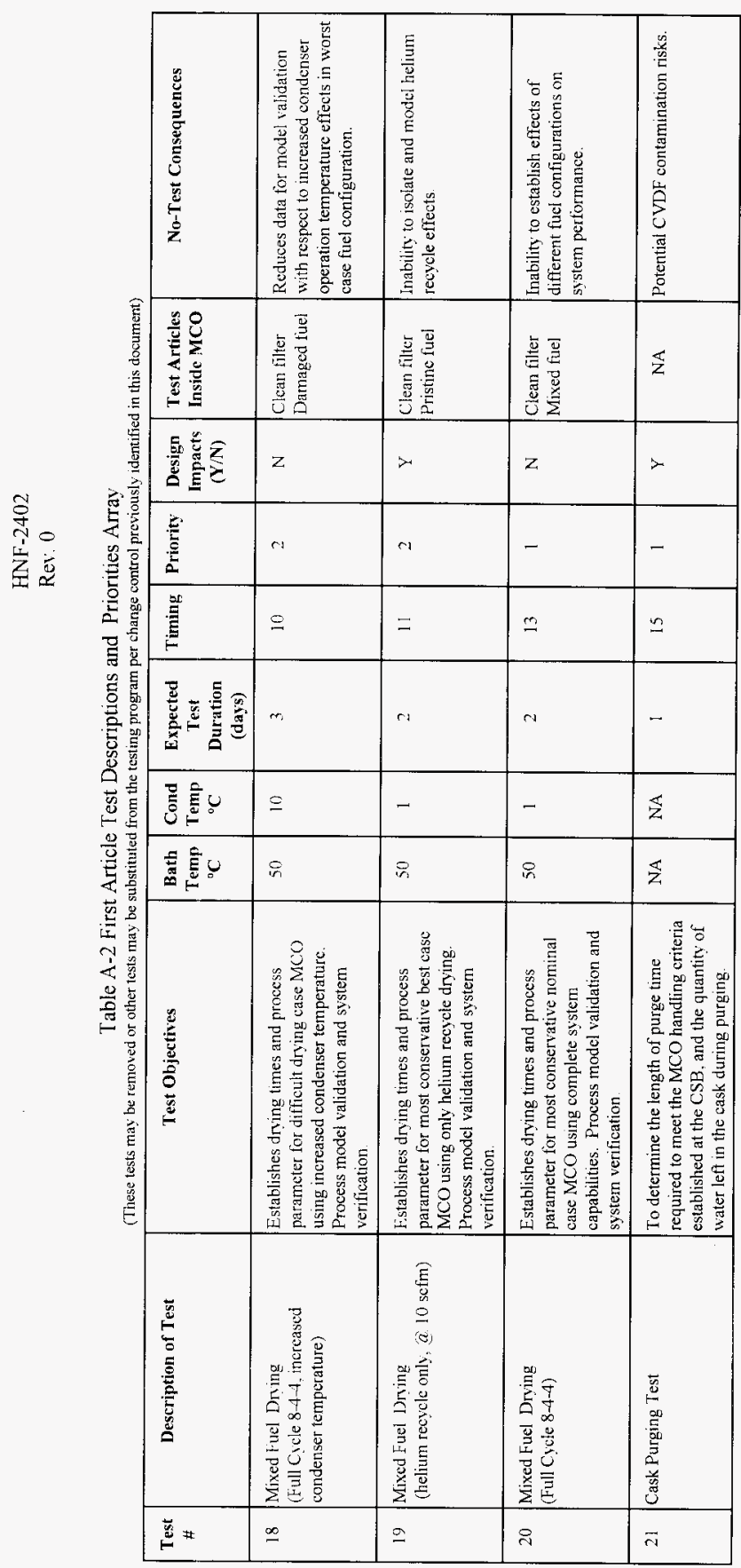


HNF-2402

Rev. 0

\section{APPENDIX B \\ EQUIPMENT DESCRIPTIONS}

\section{First Article Testing Components}

The VPS and TWS constitute the first article apparatus for CVD to undergo proof of performance testing. The rest of the CVD system including the PWC, MCO/Cask Seal Ring and Local Process Ventilation Hood systems are prototypes or mockups, which will be described in more detail as follows. Refer to the First Article Test bed layout and the First Article Testing, Piping and Instrumentation Diagram in Figure 5 (Appendix J), and the test facility, respectively, for additional information on the first article testing components. Miscellaneous instrumentation and hand isolation valving will be included in any of the test components fabricaled in the test facility.

\section{Process Water Conditioning (PWC) System}

Utilizing the design specified per the Process Water Conditioning Skid W-441-P2 Revision N procurement specification, the process water conditioning system mock-up consists of a design specified ejector jet pump, a non-prototypic pump that closely matches the flow curve of the design specified pumps, and a single tank which doubles as the water retention tank as described in section 8.2.3. The water is circulated out of the tank, through the pump, and through the ejector. The piping of the circulation system is fabricated from PVC pipe with removable unions to allow basket water inventory measurements to be completed The tank also has the capability to be heated in order to reduce MCO heating time. The system includes the capability for water removal from the tank to the $\mathrm{MCO}$, filling the MCO through the MCO long dip tube. All piping to the PWC skid from the VPS skid is prototypic (equivalent length and inside diameter) and the piping from the PWC skid boundary flange to the ejector is prototypic with the exception of the inline flow meter and pressure instrumentation.

\section{MCO}

The MCO for the CVD first article testing is the Phase I prototype mechanical closurc MCO. Shield plug modifications described in section 8.2 .3 simulate the actual MCO process connections that CVDF operations personnel shall be required to perform in the field. The modifications also include provisions for simulating the shicld plug flow paths and pressure losses through the internal filters and shield plug.

Three mockup fuel configurations are planned for performance testing in the $\mathrm{MCO}$; note that sludge will not be included in these configurations. The fuel configurations are defined as:

Pristinc Fucl: Unpainted carbon steel tubing that simulates the N Reactor fuel in geometry, assembled in a fuel basket. (Consisting of an inner and outer fuel element with nearly the same outside and inside diameter and wall thickness.) Scrap fuel (undamaged) and scrap fucl basket are included, scrap "fincs" are not.

Damaged Fuel: Same as pristine fucl, except that all fuel "clements " are damaged to provide water retention sites and debris similar to that observed for $\mathrm{K}$ Basin fuel with open end caps Scrap fucl (damaged), the scrap fucl basket and scrap "fines" are included.

Mixed Fucl: Combination of pristine and damaged fuel (approximately $37 \%$ damaged fuel); scrap fucl (damaged and undamaged), the scrap fuel basket and scrap "fines" arc included. 
Based on permutations of the above test cycles and mock fuel configurations, a number of performance proof tests will be constructed and described in the following sections.

\section{Cask}

The cask used in $306 \mathrm{E}$ Building proof of performance testing is an actual transportation cask identical to those that will be used to transport an MCO to the CVDF and CSB. Due to 306E facility limitations, the cask was removed from the cask transporter and placed on a cask load distribution frame that will closely simulate the transporter deck height and access catwalk. The distribution frame will also simulate the bottom cask port access.

\section{Seal Ring Assembly}

The scal ring prototype that provides the closure of the Cask/MCO annulus closure was fabricated per the design specified in the Process Hood, Seal Ring and Piping Assembly W-441-P4 Revision N procurement specification utilizing carbon steel components.

\section{Process Ventilation Hood Piping Assembly}

The process hood piping prototype assembly was fabricated per the Process Hood, Scal Ring and Piping Assembly W-441-P4 Revision N procurement specification utilizing carbon steel or stainless steel schedule 40 piping and valving. The piping assembly does not have redundant isolation valves or redundant instrumentation as required by the design. The framework to hold the piping was constructed entirely from uni-strut rather than the design specified 3 in. by 3 in. angle iron. The framework was mounted to the cask load distribution frame catwalk and provides a "home" position for the process ventilation hood and seal ring assemblies. Heat tape and insulation will not be installed for the first article testing, however if testing results indicate the heat trace and insulation needs, they will be installed.

\section{Process Ventilation Hood}

The process ventilation hood prototype was fabricated per the Process Hood, Seal Ring and Piping Asscmbly W-44 I-P4 Revision N procurement specification utilizing carbon or galvanized steel riveted together rather than welding per the design.

\section{SC Helium Injection and SCIC Systems}

The SC Helium Injection system was mocked up referencing Safety Class Helium System Equipment W-441-P5 Revision N procurement specification. The mock-up will provide helium injection to MCO process connectors from both a single bottle and the VPS/TWS skid main helium supply. All system redundancy has been removed for the purpose of this testing. The injection system was fabricated only from $1 / 4$ in tubing rather than pipe and welded fittings. The system pressure was maintained using readily available regulators at the test facility. System back pressure regulators were procured referencing the Safety Class Helium System I \& C W-441-P6 Revision N procurement specification. Tubing runs simulate the design specified piping runs

The SC Instrumentation and Controls will not be utilized during first article testing, however many of the instruments and valves designated in the SC I \& $\mathrm{C}$ are required for proper operation of the process. Again, redundancy will not be included in the fabrication of the safety class system mock-ups. 


\section{APPENDIX C \\ TEST PROCEDURE EXCEPTION INSTRUCTIONS}

Instructions

1 The test procedure exception is documented per the following instructions using the Exception Log provided in the log book and the Test Procedure Exception form attached.

2 Record serial number and short description of the exception in the test procedurc exception log provided.

3 Detcrminc the approval designator for the exception per HNF-PRO-233 Review and Approval of Documents and enter approval designation on the test procedure exception form.

4 Enter the next test procedure exception serial number. Make an entry in the test log book. A redlined note in the appropriate procedure section shall be made so that the exception is easily identificd and traceable.

5 Enter a detailed description of the exception including procedure section, page etc. or for procedurc changes the exception form may be attached to the form that shows the "as is" conditions and the "should be" conditions in the log book.

For procedure changes, ncw type-written pages may be substituted. Pages being replaced must be saved in Appendix D. The test procedurc exception number, date, and initials of the person making the change must appear on each page in the vicinity of the change. All replaced pages shall be marked "REPLACED" and retained in Appendix D of the controlled copy of the test procedure.

Enter the disposition to the exception

8 Based on the approval designator and cxception contents obtain the required test procedurc exception approvals.

Insert the completed form in the test logbook. 


\section{TEST PROCEDURE EXCEPTION LOG}

\section{TEST PROCEDURE EXCEPTION LOG}

Instructions: Enter the next sequential serial number, i.e. 001, and a short description of the exception. Fill out the exception form using the serial number obtained from this log.

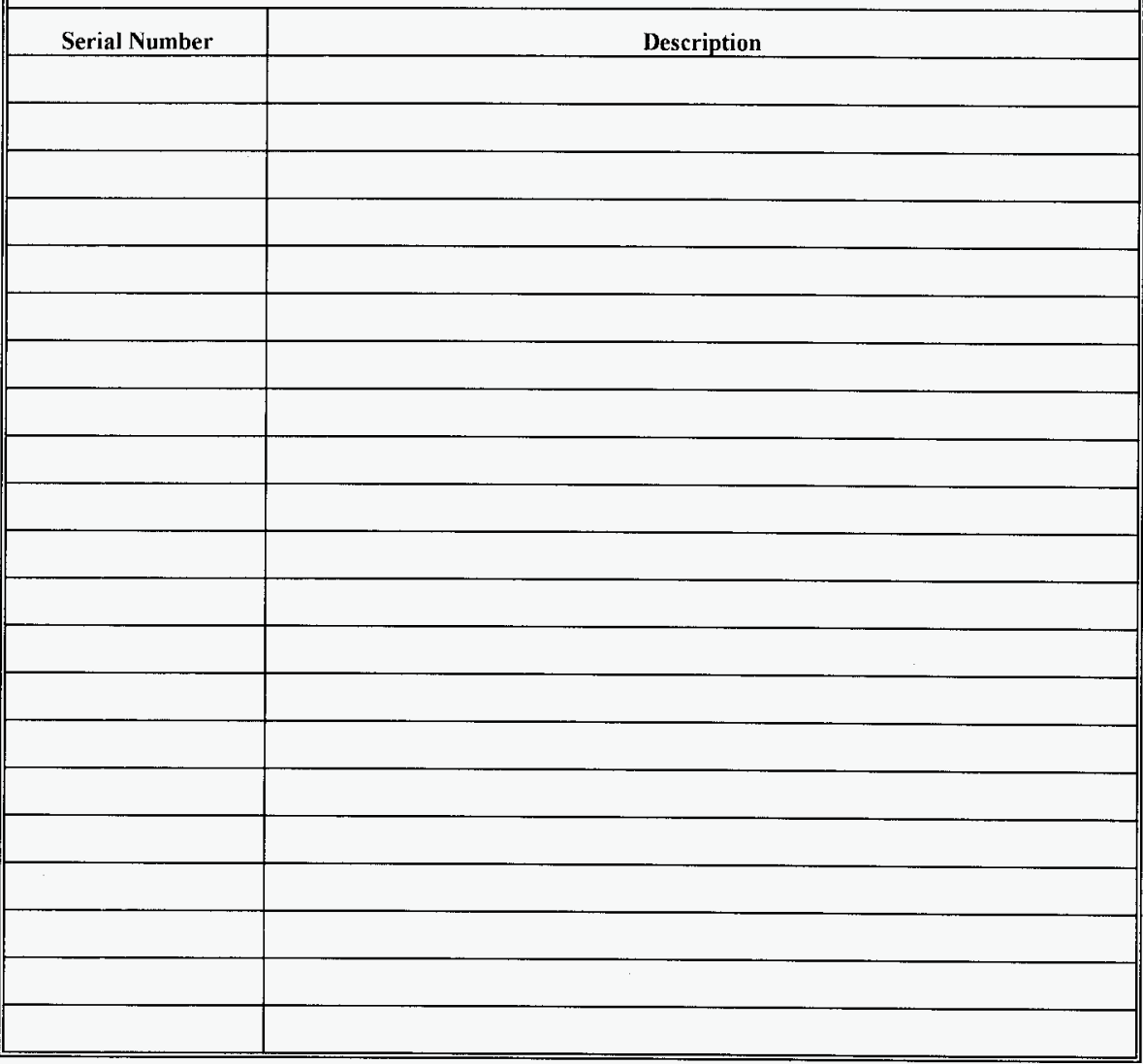


TEST PROCEDURE EXCEPTION

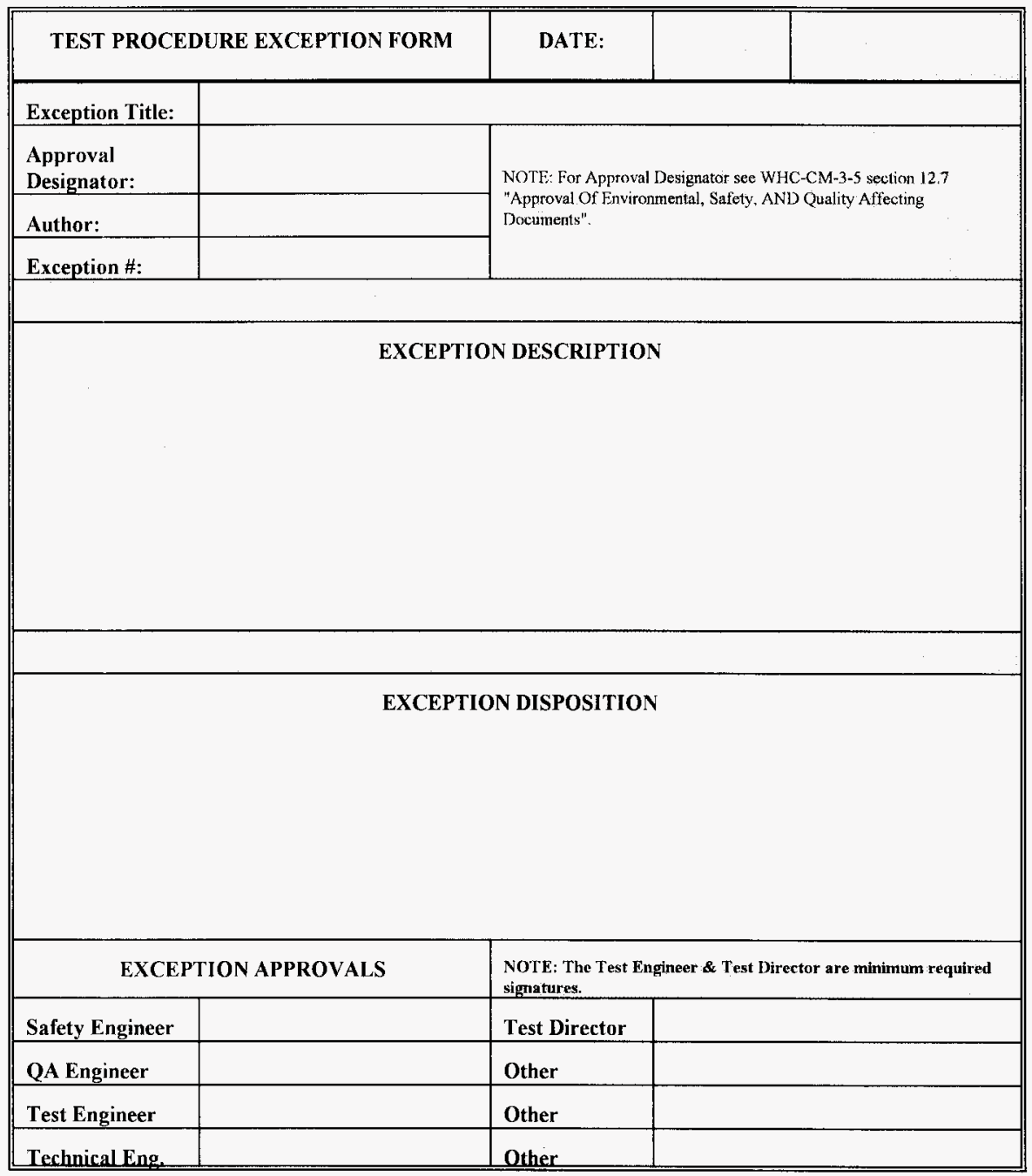


$\mathrm{HNF}-2402$

Rev. 0

APPENDIX D

CHANGED PAGES

D. 1 


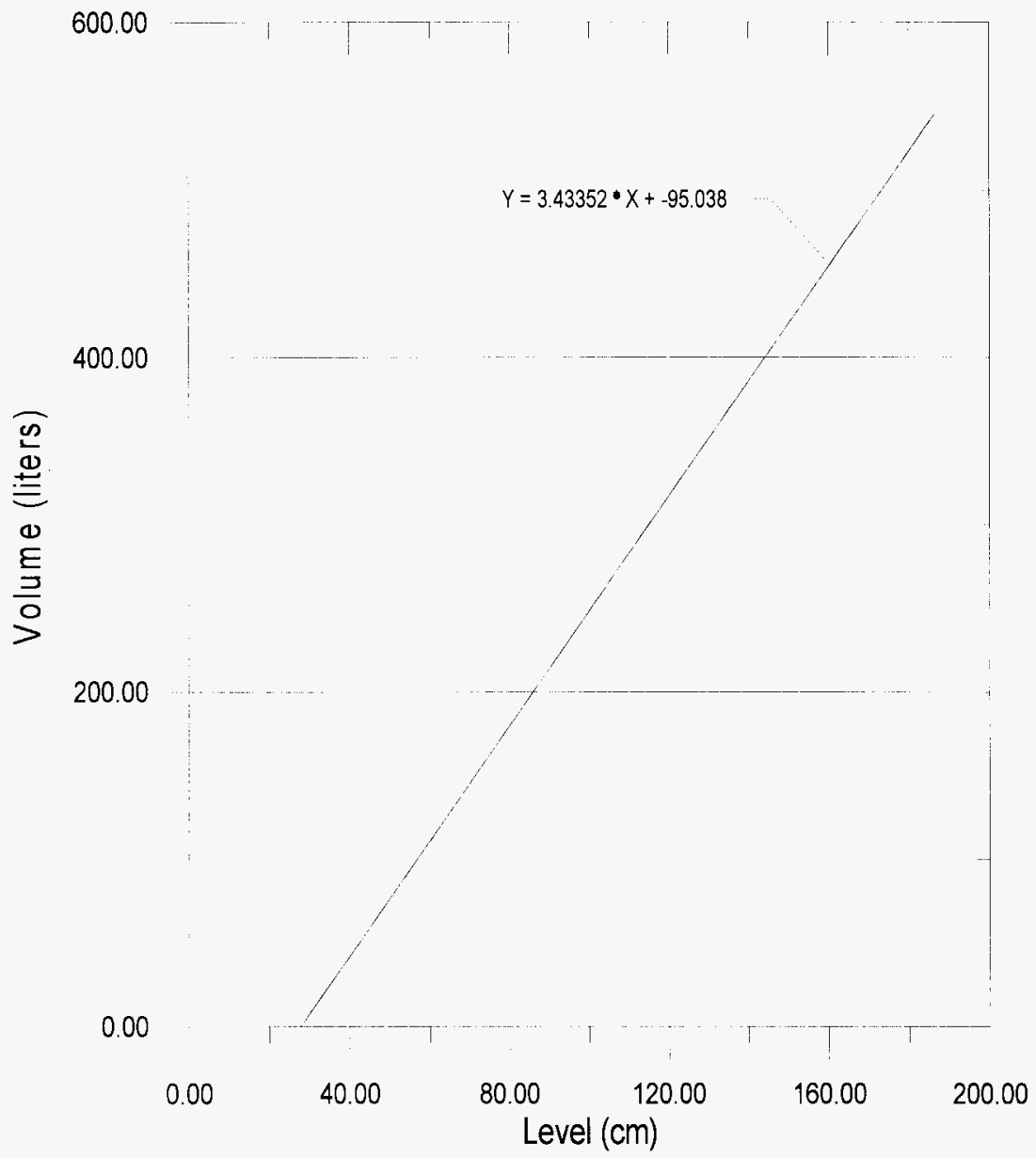

Note: Curve determined from "As Mcasured" data and utilizing Grapher ${ }^{1}$ computer software version 1.30.

${ }^{1}$ Grapher is a registered trademark of Golden Software, Golden, Colorado. 
HNF-2402

Rev. 0

APPENDIX F

INSTRUMENT CALIBRATION RECORDS 


\begin{tabular}{|c|c|c|c|c|c|c|c|c|c|c|}
\hline & \multicolumn{6}{|c|}{ Component } & \multicolumn{4}{|c|}{ First Article Calibration (Records in Appendix F) } \\
\hline $\begin{array}{l}\text { Item } \\
\text { No. }\end{array}$ & $\mathrm{P \& ID}$ & $\begin{array}{c}\text { Component } \\
\text { Tag \# }\end{array}$ & Component Description & Units & $\begin{array}{l}\text { Leak } \\
\text { Tightness }\end{array}$ & $\begin{array}{c}\text { Procurement } \\
\text { Specification Reference }\end{array}$ & $\begin{array}{l}\text { NIST/ } \\
\text { HSL }\end{array}$ & $\begin{array}{c}306 E \text { CAL } \\
Q C \\
\text { VERIFY } \\
\end{array}$ & Manufacturer & QC Signature \\
\hline & & & $\begin{array}{c}\text { VPS/HOOD } \\
\text { INSTRUMENTATION } \\
\end{array}$ & & & & & & & \\
\hline 1 & H-1-82161 & PDIT-1*34 & $\begin{array}{l}\text { MCO Differential Pressurc } \\
\text { Indicator/Transmitter }\end{array}$ & IN. $\mathrm{H} 2 \mathrm{O}$ & MLSD & W-441-P4 & $\mathrm{x}$ & & & \\
\hline 2 & H-1-82161 & Pl- I*40 & MCO Pressure Local Indicator & $\begin{array}{l}\text { PSI } / \\
\text { IN. Hg }\end{array}$ & MLSD & W-441-P4 & $\mathrm{NA}$ & NA & NA & \\
\hline 3 & H-1-82161 & PT $-1^{*} 08$ & $\begin{array}{l}\text { MCO Pressure Transmitter to } \\
\text { SCIC }\end{array}$ & TORR & MLSD & $W-441-P 4$ & $\mathrm{X}$ & & & \\
\hline 4 & H-1-82161 & $\mathrm{PT}-1 * 36$ & $\begin{array}{l}\text { MCO Pressure Transmitter to } \\
\text { SCIC }\end{array}$ & PSI & MLSD & W-441-P4 & $\mathrm{x}$ & & & \\
\hline 5 & $\mathrm{H}-1-82162$ & $\mathrm{AE}-2 * 13$ & $\begin{array}{l}\text { Residual Gas Analyzer - } \\
\text { "EVR" Inlet Valve }\end{array}$ & AMU & MLSD & W-441-P1 & & & $X$ & \\
\hline 6 & H-1-82162 & FE-2*12 & $\begin{array}{l}\text { VPS Condenser Inlet Flow } \\
\text { Element }\end{array}$ & SCFM & MLSD & W-441-P1 & & & $\mathrm{X}$ & \\
\hline 7 & H-1-82162 & LSH-2*25 & $\begin{array}{l}\text { VPS Condenser Level Switch } \\
\text { High }\end{array}$ & NA & MLSD & W-44l-P I & & $\begin{array}{l}\text { MCS } \\
\text { CAT }\end{array}$ & & \\
\hline 8 & H-1-82161 & MT- $1 * 16$ & $\begin{array}{l}\text { MCO Outlet Moisture } \\
\text { Indicator Transmitter }\end{array}$ & deg. C & MLSD & W-441-P1 & & & $\mathrm{X}$ & \\
\hline 9 & H-1-82161 & PDIT-1*13 & $\begin{array}{l}\text { MCO Inlet HEPA Differential } \\
\text { Pressure Indicator/Transmitter }\end{array}$ & IN. $\mathrm{H} 2 \mathrm{O}$ & MLSD & W-441-P1 & & & $\mathrm{X}$ & \\
\hline 10 & H-1-82162 & PIT-2*08 & $\begin{array}{l}\text { VPS Vacuum Inlet Pressure } \\
\text { Indicator/Transmitter }\end{array}$ & TORR & MLSD & W-441-P1 & & & $x$ & \\
\hline 11 & H-I.82162 & PIT-2*09 & $\begin{array}{l}\text { VPS Vacuum Inlet Pressure } \\
\text { Indicator/Transmitter }\end{array}$ & TORR & MLSD & W-44l-P1 & & & $\mathrm{X}$ & \\
\hline 12 & $\mathrm{H}=1.82162$ & PIT-2*11 & $\begin{array}{l}\text { VPS Condenser Inlet Pressure } \\
\text { Indicator/Transmitter }\end{array}$ & TORR & MLSD & W-441-P I & & & $\mathrm{X}$ & \\
\hline 13 & H-1-82162 & AT-2*13 & $\begin{array}{l}\text { Residual Gas Analyzer - } \\
\text { Transmitter }\end{array}$ & AMU & NA & W-441-P1 & & & $\mathrm{X}$ & \\
\hline 14 & H-1-82162 & FIT $-2 * 12$ & $\begin{array}{l}\text { VPS Condenser Inlet Flow } \\
\text { Indicator/Transmitter }\end{array}$ & SCFM & NA & W-441-P1 & & & $\mathrm{X}$ & \\
\hline
\end{tabular}




\begin{tabular}{|c|c|c|c|c|c|c|c|c|c|c|}
\hline & \multicolumn{6}{|c|}{ Component } & \multicolumn{4}{|c|}{ First Article Calibration (Records in Appendix F) } \\
\hline $\begin{array}{l}\text { Item } \\
\text { No. }\end{array}$ & P\&ID & $\begin{array}{l}\text { Component } \\
\text { Tag \# }\end{array}$ & Component Description & Units & $\begin{array}{l}\text { Leak } \\
\text { Tightness }\end{array}$ & $\begin{array}{c}\text { Procurement } \\
\text { Specification Reference }\end{array}$ & $\begin{array}{l}\text { NIST/ } \\
\text { HSL }\end{array}$ & $\begin{array}{c}306 \mathrm{ECAL} \\
\text { QC } \\
\text { VERIFY }\end{array}$ & Manufacturer & QC Signature \\
\hline 15 & $H \cdot I-8216 I$ & Ti/TIT-1*07 & $\begin{array}{l}\text { VPS Condenser Gas Inlet } \\
\text { Temperature } \\
\text { Indicator/Transmitter } \\
\end{array}$ & deg. C & $\mathrm{NA}$ & W-44l-Pl & & & $\mathrm{X}$ & \\
\hline 16 & $\mathrm{H}-1-82162$ & TI/TIT $-2 * 14$ & $\begin{array}{l}\text { VPS Condenser Outlet } \\
\text { Temperature } \\
\text { Indicator/Transmitter }\end{array}$ & deg. C & NA & W-44l-PI & & & $\mathrm{X}$ & \\
\hline 17 & H-l-82162 & TI/TIT $-2 * 15$ & $\begin{array}{l}\text { VPS Vacuum Pump Outlet } \\
\text { Temperature } \\
\text { Indicator/Transmitter } \\
\end{array}$ & deg. C & NA & W-441-P1 & & & $\mathrm{X}$ & \\
\hline 18 & H-l-82l62 & TIT $-2 * 18$ & $\begin{array}{l}\text { VPS Blower Discharge } \\
\text { Temperature } \\
\text { Indicator/Transmitter }\end{array}$ & deg. C & NA & W-441-P1 & & & $\mathrm{X}$ & \\
\hline 19 & H-1-82162 & TIT $-2 * 35$ & $\begin{array}{l}\text { VPSCHW Condenser Inlet } \\
\text { Temperature } \\
\text { Indicator/Transmitter } \\
\end{array}$ & deg. C & NA & W-441-P1 & & $\mathrm{X}$ & & \\
\hline 20 & H-1-82162 & TIT-2*36 & $\begin{array}{l}\text { VPSCHW Condenser Outlet } \\
\text { Temperature } \\
\text { Indicator/Transmitter } \\
\end{array}$ & deg. C & NA & $\mathrm{W}-441-\mathrm{P} 1$ & & $X$ & & \\
\hline 21 & H-1-82161 & ZS-1*09 & $\begin{array}{l}\text { MCO Short Dip Tube } \\
\text { Isolation Valve Position } \\
\text { Switch }\end{array}$ & $\begin{array}{l}\text { OPEN/ } \\
\text { CLOSE }\end{array}$ & NA & W-441-P4 & & $\begin{array}{l}\text { MCS } \\
\text { CAT }\end{array}$ & & \\
\hline 22 & $\mathrm{H}-\mathrm{I}-82161$ & ZS-1*11 & $\begin{array}{l}\text { MOV 1*11 Valve Position } \\
\text { Switch }\end{array}$ & \begin{tabular}{|l|} 
DV/ \\
CLOSED \\
/VPS \\
\end{tabular} & $\mathrm{NA}$ & W-441-P4 & & $\begin{array}{l}\text { MCS } \\
\text { CAT }\end{array}$ & & \\
\hline 23 & H-1-82161 & ZS-1*17 & $\begin{array}{l}\text { MCO Long Dip Tube } \\
\text { Isolation Valve Position } \\
\text { Switch }\end{array}$ & $\begin{array}{l}\text { OPEN/ } \\
\text { CLOSE }\end{array}$ & NA & W-44I-P4 & & $\begin{array}{l}\text { MCS } \\
\text { CAT }\end{array}$ & & \\
\hline 24 & H-1-82162 & $\mathrm{ZS}-2 * 03$ & $\begin{array}{l}\text { VPS Condenser Bypass Valve } \\
\text { Position Switch }\end{array}$ & $\begin{array}{l}\text { OPEN/ } \\
\text { CLOSE }\end{array}$ & NA & W-44I-PI & & $\begin{array}{l}\text { MCS } \\
\text { CAT }\end{array}$ & & \\
\hline 25 & H-I -82162 & $\mathrm{ZS}-2 * 04$ & $\begin{array}{l}\text { VPS Blower Inlet Valve } \\
\text { Position Switch }\end{array}$ & $\begin{array}{l}\text { OPEN/ } \\
\text { CLOSE }\end{array}$ & NA & W-44l-Pl & & $\begin{array}{l}\text { MCS } \\
\text { CAT }\end{array}$ & & \\
\hline
\end{tabular}




\begin{tabular}{|c|c|c|c|c|c|c|c|c|c|c|}
\hline & \multicolumn{6}{|c|}{ Component } & \multicolumn{4}{|c|}{ First Article Calibration (Records in Appendix F) } \\
\hline $\begin{array}{l}\text { Item } \\
\text { No. }\end{array}$ & P\&ID & $\begin{array}{l}\text { Component } \\
\text { Tag \# }\end{array}$ & Component Description & Units & $\begin{array}{l}\text { Leak } \\
\text { Tightness }\end{array}$ & $\begin{array}{c}\text { Procurement' } \\
\text { Specification Reference }\end{array}$ & $\begin{array}{l}\text { NIST/ } \\
\text { HSL }\end{array}$ & $\begin{array}{c}306 \mathrm{ECAL} \\
\text { QC } \\
\text { VERIFY }\end{array}$ & Manufacturer & QC Signature \\
\hline 26 & $\mathrm{H}-1-82162$ & $25-2 * 05$ & $\begin{array}{l}\text { VPS Vacuum and Blower } \\
\text { Bypass Valve Position Switch }\end{array}$ & $\begin{array}{l}\text { OPEN/ } \\
\text { CLOSE }\end{array}$ & $\mathrm{NA}$ & $\mathrm{W}-44 \mathrm{l}-\mathrm{PI}$ & & $\begin{array}{l}\text { MCS } \\
\text { CAT } \\
\end{array}$ & $=$ & \\
\hline 27 & $\mathrm{H}-1-82162$ & ZS-2*07 & $\begin{array}{l}\text { VPS Vacuum Pump Inlet } \\
\text { Valyc Position Switch }\end{array}$ & $\begin{array}{l}\text { OPEN/ } \\
\text { CLOSE }\end{array}$ & $\mathrm{NA}$ & W-44I-PI & & $\begin{array}{l}\text { MCS } \\
\text { CAT }\end{array}$ & & \\
\hline 28 & H-1-82162 & $2 \mathrm{~S}-2 * 21$ & $\begin{array}{l}\text { VPS Condenser Outlet Valve } \\
\text { Position Switch }\end{array}$ & $\begin{array}{l}\text { OPEN/ } \\
\text { CLOSE }\end{array}$ & NA & W-441-P1 & & $\begin{array}{l}\text { MCS } \\
\text { CAT }\end{array}$ & & \\
\hline 29 & H-l-82162 & $\mathrm{ZS}-2 * 22$ & $\begin{array}{l}\text { VPS Condenser Inlet Valve } \\
\text { Position Switch }\end{array}$ & $\begin{array}{l}\text { OPEN/ } \\
\text { CLOSE }\end{array}$ & NA & W-441-Pl & & $\begin{array}{l}\text { MCS } \\
\text { CAT }\end{array}$ & & \\
\hline 30 & H-1-82162 & ZS $-2 * 28$ & $\begin{array}{l}\text { Blower Return Line to MCO, } \\
\text { GOV } 2 * 28 \text { Valve Position } \\
\text { Switch }\end{array}$ & $\mid \begin{array}{l}\text { OPEN/ } \\
\text { CLOSE }\end{array}$ & NA & W-441-P1 & & $\begin{array}{l}\text { MCS } \\
\text { CAT }\end{array}$ & & \\
\hline & & & $\begin{array}{l}\text { COMPRESSED AIR } \\
\text { INSTRUMENTATION }\end{array}$ & & & & & & & \\
\hline 31 & H-1-82161 & $\mathrm{F}[-1 * 33$ & $\begin{array}{l}\text { CA to VPS Flow Indicator: } \\
\text { Rotameter }\end{array}$ & SCFM & NA & W-441-P1 & & & $\mathrm{X}$ & \\
\hline 32 & H-1-82161 & PIT-1*04 & $\begin{array}{l}\text { Cask/MCO Seal Ring } \\
\text { Pressure Indicator/Transmitter }\end{array}$ & PSIG & NA & W-44l-Pl & & & $\mathrm{X}$ & \\
\hline 33 & H-1-82161 & $2 S-1 * 15$ & $\begin{array}{l}\text { TW Compress Air Supply to } \\
\text { Cask Valve Position Switch }\end{array}$ & $\begin{array}{l}\text { OPEN/ } \\
\text { CLOSE } \\
\end{array}$ & NA & W-441-Pl & & $\begin{array}{l}\text { MCS } \\
\text { CAT }\end{array}$ & $x$ & \\
\hline & & & $\begin{array}{c}\text { HELIUM SUPPLY } \\
\text { INSTRUMENTATION } \\
\end{array}$ & & & & & & & \\
\hline 34 & $\mathrm{H}-1-82161$ & FE-1*19 & $\begin{array}{l}\text { Normal Helium to MCO Flow } \\
\text { Element }\end{array}$ & SCFM & NA & W-441-P1 & & & $\mathrm{X}$ & \\
\hline 35 & H-l-82161 & FIT-1*19 & $\begin{array}{l}\text { Normal Helium to MCO Flow } \\
\text { Indicator/Transmitter }\end{array}$ & SCFM & NA & W-441-P1 & & & $\mathrm{X}$ & \\
\hline 36 & H-1-82161 & $Z S-1 * 12$ & $\begin{array}{l}\text { Normal He Supply Isolation } \\
\text { Valve Position Switch } \\
\end{array}$ & $\begin{array}{l}\text { OPEN/ } \\
\text { CLOSE }\end{array}$ & NA & W-44l-Pl & & $\begin{array}{l}\mathrm{MCS} \\
\mathrm{CAT}\end{array}$ & & \\
\hline 37 & H-1-82161 & $Z S-1 * 06$ & $\begin{array}{l}\text { MCO Short Dip Tube Iso to } \\
\text { Normal He, Valve Pos Switch } \\
\end{array}$ & $\begin{array}{l}\text { OPEN/ } \\
\text { CLOSE }\end{array}$ & NA & $W-441-P 4$ & & $\begin{array}{l}\text { MCS } \\
\text { CAT }\end{array}$ & & \\
\hline & & & SCHC INSTRUMENTATION & & & & & & & \\
\hline
\end{tabular}




\begin{tabular}{|c|c|c|c|c|c|c|c|c|c|c|}
\hline & \multicolumn{6}{|c|}{ Component } & \multicolumn{4}{|c|}{ First Article Calibration (Records in Appendix F) } \\
\hline $\begin{array}{l}\text { Item } \\
\text { No. }\end{array}$ & P\&ID & $\begin{array}{c}\text { Component } \\
\text { Tag \# }\end{array}$ & Component Description & Units & $\begin{array}{l}\text { Leak } \\
\text { Tightness }\end{array}$ & $\begin{array}{c}\text { Procurement } \\
\text { Specification Reference }\end{array}$ & $\begin{array}{c}\text { NIST/ } \\
\text { HSL }\end{array}$ & $\begin{array}{c}\text { 306E CAL } \\
\text { QC } \\
\text { VERIFY }\end{array}$ & Manufacturer & QC Signature \\
\hline 38 & $H-1-82165$ & $\mathrm{PI}-5 * 48$ & $\begin{array}{l}\text { SCHe } 2 \text { psig Pressure } \\
\text { Indicator }\end{array}$ & PSIG & $\mathrm{MLSD}$ & $\mathrm{W}-441-\mathrm{P} 5$ & & $X$ & & \\
\hline 39 & $H-1-82165$ & PI-5*46 & $\begin{array}{l}\mathrm{SCHe} 15 \text { psig Pressure } \\
\text { Indicator }\end{array}$ & PSIG & MLSD & W-44I-P5 & & $\mathrm{X}$ & & \\
\hline 40 & H-1-82165 & PI-5*09 & $\begin{array}{l}\text { SCHe } 7 \text { psig Pressure } \\
\text { Indicator }\end{array}$ & PSIG & MLSD & $\mathrm{W}-441-\mathrm{P} 5$ & & $\mathrm{X}$ & & \\
\hline 41 & H-1.82l65 & $\mathrm{PI}-5 * 07$ & $\begin{array}{l}\text { SCHe } 15 \text { psig Pressure } \\
\text { Indicator }\end{array}$ & PSIG & MLSD & W-441-P5 & & $\mathrm{X}$ & & \\
\hline 42 & H-1 -82165 & PI-5*02 & $\begin{array}{l}\text { SCHe Bottle Pressure Local } \\
\text { Indicator }\end{array}$ & PSIG & MLSD & W-441-P5 & & $\mathrm{X}$ & & \\
\hline 43 & H-1-82165 & FI- $5^{*} 52$ & $\begin{array}{l}\text { SCHe Flow Indication to } \\
\text { Vent: Rotameter }\end{array}$ & SCFM & MLSD & W-441-P5 & & & $\mathrm{X}$ & \\
\hline 44 & $\mathrm{H}-1-82165$ & $\mathrm{FI}-5 * 49$ & $\begin{array}{l}\text { SCHe Flow Indication to } \\
\text { MCO; Rotameter }\end{array}$ & SCFM & MLSD & W-441-P5 & & & $\mathrm{X}$ & \\
\hline 45 & H-1-82165 & $\mathrm{FI}-5 * 10$ & $\begin{array}{l}\text { SCHe Flow Indication to } \\
\text { MCO; Rotameter }\end{array}$ & SCFM & MLSD & W-441-P5 & & $\mathrm{X}$ & & \\
\hline 46 & H-1-82165 & $2 \mathrm{~S}-5 * 51$ & $\begin{array}{l}\text { SCHe Isolation Valve Position } \\
\text { Indicator Switch }\end{array}$ & $\begin{array}{l}\text { OPEN/ } \\
\text { CLOSE }\end{array}$ & NA & W-44l-P5 & & $\begin{array}{l}\text { MCS } \\
\text { CAT }\end{array}$ & & \\
\hline 47 & H-1-82165 & $2 S-5 * 12$ & $\begin{array}{l}\text { SCHe Isolation Valve Position } \\
\text { Indicator Switch }\end{array}$ & $\begin{array}{l}\text { OPEN/ } \\
\text { CLOSE }\end{array}$ & NA & W-441-P5 & & $\begin{array}{l}\text { MCS } \\
\text { CAT }\end{array}$ & & \\
\hline & & & $\begin{array}{c}\text { DI WATER } \\
\text { INSTRUMENTATION }\end{array}$ & & & & & & & \\
\hline 48 & H-1-82161 & $\mathrm{FI}-1 * 31$ & $\begin{array}{l}\text { DI Water Inlet to flex line } \\
\text { Flow Indicator; Rotameter }\end{array}$ & GPM & NA & W-44l-P5 & & & $\mathrm{X}$ & \\
\hline 49 & H-I-82161 & ZS- $1^{*} 01$ & $\begin{array}{l}\text { DI Water Isolation Valve } \\
\text { Position Switch }\end{array}$ & $\begin{array}{l}\text { OPEN/ } \\
\text { CLOSE }\end{array}$ & $\mathrm{NA}$ & $\mathrm{W}-441-\mathrm{P} 1$ & & $\begin{array}{l}\text { MCS } \\
\text { CAT }\end{array}$ & & \\
\hline & & & PWC INSTRUMENTATION & & & & & & & \\
\hline 50 & H-1-82164 & PIT-4038 & $\begin{array}{l}\text { PWC Pump Recirc Pressure } \\
\text { Indicator/Transmitter }\end{array}$ & PSIG & Hydrotest & $\mathrm{W}-441-\mathrm{P} 2$ & & $x$ & & \\
\hline 51 & H-1-82164 & PIT-403I & $\begin{array}{l}\text { PWC Ejector Inlet Pressure } \\
\text { Indicator/Transmitter }\end{array}$ & $\begin{array}{l}\mathrm{PSIG} / " \\
\mathrm{H} 20\end{array}$ & Hydrotest & $\mathrm{W}-441-\mathrm{P} 2$ & & $\mathrm{X}$ & & \\
\hline
\end{tabular}




\begin{tabular}{|c|c|c|c|c|c|c|c|c|c|c|}
\hline & \multicolumn{6}{|c|}{ Component } & \multicolumn{4}{|c|}{ First Article Calibration (Records in Appendix F) } \\
\hline $\begin{array}{l}\text { Item } \\
\text { No. }\end{array}$ & P\&ID & $\begin{array}{c}\text { Component } \\
\text { Tag \# }\end{array}$ & Component Description & Units & $\begin{array}{l}\text { Leak } \\
\text { Tightness }\end{array}$ & $\begin{array}{c}\text { Procurement } \\
\text { Spccification Reference }\end{array}$ & $\begin{array}{l}\text { NIST/ } \\
\text { HSL }\end{array}$ & $\begin{array}{c}306 \mathrm{ECAL} \\
\text { QC } \\
\text { VERLFY }\end{array}$ & Manufacturer & QC Signature \\
\hline 52 & $\mathrm{H}-\mathrm{l}-82164$ & FE-4050 & PWC Ejector Flow Element & GPM & Hydrotest & $\mathrm{W}-441-\mathrm{P} 2$ & & $\mathrm{X}$ & & \\
\hline 53 & H-I-82162 & ZS-2*16 & $\begin{array}{l}\text { VPS Condenser Drain Valve } \\
\text { Position Switch }\end{array}$ & $\begin{array}{l}\text { OPEN/ } \\
\text { CLOSE }\end{array}$ & NA & W-44I-PI & & $\begin{array}{l}\mathrm{MCS} \\
\mathrm{CAT}\end{array}$ & & \\
\hline 54 & H-1-82161 & ZS- $1 * 30$ & $\begin{array}{l}\text { VPS to PWC Isolation Valie } \\
\text { Local Position Indication, } \\
\text { (Switch is non-safety) }\end{array}$ & $\begin{array}{l}\text { OPEN/ } \\
\text { CLOSE }\end{array}$ & NA & W-441-P4 & & $\begin{array}{l}\text { MCS } \\
\text { CAT }\end{array}$ & & \\
\hline 55 & H-I-8216] & ZS-1*02 & $\begin{array}{l}\text { MCO Long Dip Tube } \\
\text { Isolation Valve Position } \\
\text { Switch }\end{array}$ & $\begin{array}{l}\text { OPEN/ } \\
\text { CLOSE }\end{array}$ & NA & $\mathrm{W}-441-\mathrm{P} 4$ & & $\begin{array}{l}\text { MCS } \\
\text { CAT }\end{array}$ & & \\
\hline 57 & H. 1.82164 & LE-4033 & $\begin{array}{l}\text { PWC Receiver Tanks Level } \\
\text { Element }\end{array}$ & $\Gamma \mathrm{N}$ & Hydrotest & $\mathrm{W}-441-\mathrm{P} 2$ & & $\mathrm{X}$ & & \\
\hline 59 & H- $1-82164$ & FIT -4050 & $\begin{array}{l}\text { PWC Ejector Inlet Flow } \\
\text { Indicator/Transmitter }\end{array}$ & GPM & NA & $\mathrm{W}-441-\mathrm{P} 2$ & & $\mathrm{X}$ & & \\
\hline & & & TWS INSTRUMENTATION & & & & & & & \\
\hline 61 & H-1-82163 & ZS-3*14 & $\begin{array}{l}\text { TW MCO Inlet GOV } 3 * 14 \\
\text { Valve Position Switch }\end{array}$ & $\begin{array}{l}\text { OPEN/ } \\
\text { CLOSE }\end{array}$ & NA & W-441-P1 & & $\begin{array}{l}\text { MCS } \\
\text { CAT }\end{array}$ & & \\
\hline 62 & H-1-82161 & ZS-1*14 & $\begin{array}{l}\text { TW MCO Outlet GOV 1*14 } \\
\text { Valve Position Switch }\end{array}$ & $\begin{array}{l}\text { OPEN/ } \\
\text { CLOSE }\end{array}$ & NA & W-441-P1 & & $\begin{array}{l}\text { MCS } \\
\text { CAT }\end{array}$ & & \\
\hline 63 & $\mathrm{H}-1-82163$ & TIT $-3 * 13$ & $\begin{array}{l}\text { TW Heater Inlet Temperature } \\
\text { Indicator/Transmitter }\end{array}$ & deg. C & NA & $\mathrm{W}-441-\mathrm{P} 1$ & & & $\mathrm{x}$ & \\
\hline 64 & H-1-82163 & TIT $-3 * 12$ & $\begin{array}{l}\text { TW MCO Outlet Temperature } \\
\text { Indicator/Transmitter }\end{array}$ & deg. C & NA & $\mathrm{W}-441-\mathrm{P} 1$ & & & $\mathrm{X}$ & \\
\hline 65 & H-1-82163 & TIT $-3 * 05$ & $\begin{array}{l}\text { TW MCO Inlet Temperature } \\
\text { Indicator/Transmitter }\end{array}$ & deg. $C$ & NA & W-441-P1 & & & $x$ & \\
\hline 66 & $\mathrm{H}-1-82 \mathrm{l} 63$ & $\mathrm{TC}-3 * 05$ & $\begin{array}{l}\text { TW Temperature Controller/ } \\
\text { Indicator }\end{array}$ & $\operatorname{deg} \mathrm{C}$ & NA & $\mathrm{W}-441-\mathrm{P} 1$ & & & $\mathrm{X}$ & \\
\hline 67 & $\mathrm{H}-1-82163$ & PIT-3*08 & $\begin{array}{l}\text { TW Pump Discharge Pressure } \\
\text { Indicator/Transmitter }\end{array}$ & PSIG & MLSD & W-441-P1 & & & $\mathrm{X}$ & \\
\hline 68 & H- $1-82163$ & LSH-3*06 & TW Tank Level Switch High & NA & MLSD & W-441-P1 & & $\begin{array}{l}\mathrm{MCS} \\
\mathrm{CAT}\end{array}$ & & \\
\hline
\end{tabular}




\begin{tabular}{|c|c|c|c|c|c|c|c|c|c|c|}
\hline & \multicolumn{6}{|c|}{ Component } & \multicolumn{4}{|c|}{ First Article Calibration (Records in Appendix F) } \\
\hline $\begin{array}{l}\text { Item } \\
\text { No. }\end{array}$ & P\&ID & $\begin{array}{l}\text { Component } \\
\text { Tag \# }\end{array}$ & Component Description & Units & $\begin{array}{l}\text { Leak } \\
\text { Tightness }\end{array}$ & $\begin{array}{l}\text { Procurement } \\
\text { Specification Reference }\end{array}$ & $\begin{array}{l}\text { NIST/ } \\
\text { HSL }\end{array}$ & $\begin{array}{l}\text { 306E.CAl: } \\
\text { QC } \\
\text { VERIIY }\end{array}$ & Manufacturer & QC Signature \\
\hline 69 & $H-1.82163$ & LIT $-3 * 04$ & $\begin{array}{l}\text { TW Tank Level Indicatori } \\
\text { Transmitter }\end{array}$ & IN. & MLSD & W-44 I-P I & & & $\mathrm{X}$ & \\
\hline 70 & H-I-82163 & LE-3*04 & TW Tank Level Element & IN. & NA & & & & $\mathrm{X}$ & \\
\hline 71 & H-1-82163 & FIT $-3 * 16$ & $\begin{array}{l}\text { TW Flow: } \\
\text { Indicator/Transmitter }\end{array}$ & GPM & NA & $\mathrm{W}-441-\mathrm{P} 1$ & & & $\mathrm{x}$ & \\
\hline 72 & H-l-82163 & $\mathrm{FE}-3 * 16$ & TW Cask Inlet Flow Element & GPM & NA & $\mathrm{W}-441-\mathrm{Pl}$ & & & $\mathrm{X}$ & \\
\hline \multirow[t]{3}{*}{73} & H-1-82163 & $Z S-3 * 01$ & $\begin{array}{l}\text { TW MCO Outlet GOV } 3 *^{*} 01 \\
\text { Valve Position Switch }\end{array}$ & $\begin{array}{l}\text { OPEN/ } \\
\text { CLOSE }\end{array}$ & NA & W-441-P1 & & $\begin{array}{l}\text { MCS } \\
\text { CAT }\end{array}$ & & \\
\hline & & & $\begin{array}{l}\text { ADDITIONAL TEST } \\
\text { INSTRUMENTATION } \\
\end{array}$ & & & & & & & \\
\hline & & & WATER RETENTION TEST & & & & & & & \\
\hline \multirow[t]{2}{*}{74} & Fig 1 & WRT & $\begin{array}{l}\text { Measures Retained Water on } \\
\text { Baskets in the MCO and PWC } \\
\text { System }\end{array}$ & Liter/Gal & Hydro & NA & $\mathrm{X}$ & $X$ & & \\
\hline & & & $\mathrm{MCO}$ & & & & & & & \\
\hline 75 & Fig. 7 & $\begin{array}{l}\text { MCO TE } \\
1-10 \\
\end{array}$ & $\begin{array}{l}\text { MCO Outer Wall Shield Plug } \\
\text { Thermocouples }\end{array}$ & deg. C & Hydro & NA & $\mathrm{X}$ & & & \\
\hline \multirow[t]{2}{*}{76} & Fig. 7 & \begin{tabular}{|l} 
FUEL TE \\
$11-22$
\end{tabular} & $\begin{array}{l}\text { Fuel and Basket } \\
\text { Thermocouples }\end{array}$ & deg. C & MSLD & NA & $\mathrm{X}$ & & & \\
\hline & & & VPS CHILLED WATER & & & & & & & \\
\hline 77 & NA & $\begin{array}{l}\text { VPSCHW } \\
\text { FLOW }\end{array}$ & $\begin{array}{l}\text { Flow Meter From VPSCHW } \\
\text { Chiller to VPS Skid }\end{array}$ & GPM & Hydro & NA & & $X$ & & \\
\hline \multirow[t]{2}{*}{78} & NA & $\begin{array}{l}\text { VPS CHW } \\
\text { INLET } \\
\text { TEMP } \\
\end{array}$ & $\begin{array}{l}\text { From VPSCHW Chiller to } \\
\text { VPS Skid }\end{array}$ & $\operatorname{deg} C$ & Hydro & NA & & $\mathrm{X}$ & & \\
\hline & & & ROOM ATMOSPHERE & & & & & & & \\
\hline \multirow[t]{2}{*}{79} & NA & $\begin{array}{l}\text { ROOM } \\
\text { TEMP }\end{array}$ & TC for Room Temp & deg. C & NA & NA & & $\mathrm{X}$ & & \\
\hline & & & CASK DRYING & & & & & & & \\
\hline
\end{tabular}




\begin{tabular}{|c|c|c|c|c|c|c|c|c|c|c|}
\hline \multirow{2}{*}{$\begin{array}{l} \\
\text { Item } \\
\text { No. }\end{array}$} & \multicolumn{6}{|c|}{ Component } & \multicolumn{4}{|c|}{ First Article Calibration (Records in Appendix F) } \\
\hline & P\&ID & $\begin{array}{c}\text { Component } \\
\text { Tag \# }\end{array}$ & Component Description & Units & $\begin{array}{l}\text { Leak } \\
\text { Tightncss }\end{array}$ & $\begin{array}{c}\text { Procurement } \\
\text { Specification Reference }\end{array}$ & $\begin{array}{l}\text { NIST/ } \\
\text { HSL }\end{array}$ & $\begin{array}{c}\text { 306E CAL } \\
\text { QC } \\
\text { VERIFY }\end{array}$ & Manufacturer & QC Signature \\
\hline 80 & NA & $\begin{array}{l}\text { Cask Dew } \\
\text { Point }\end{array}$ & $\begin{array}{l}\text { Dew Point Sensor for Cask } \\
\text { Purging }\end{array}$ & deg. C & Hydro & $\mathrm{NA}$ & & & $\mathrm{X}$ & \\
\hline & & & WATER INGRESS TEST & & & & & & & \\
\hline 81 & $\mathrm{NA}$ & PI 1 & Air Pressure & PSIG & Hydro & $\mathrm{NA}$ & & $\mathrm{X}$ & & \\
\hline 82 & $\mathrm{NA}$ & PI 2 & Water Pressure & PSIG & Hydro & NA & & $\mathrm{X}$ & & \\
\hline 83 & $\mathrm{NA}$ & FI 1 & Air flow & SCFM & Hydro & $\mathrm{NA}$ & & $\mathrm{X}$ & & \\
\hline \multirow[t]{2}{*}{84} & $\mathrm{NA}$ & FI 2 & Water flow & GPM & Hydro & NA & & $\mathrm{X}$ & & \\
\hline & & & SCHE INSTRUMENTATION & & & & & & & \\
\hline 85 & $\mathrm{H}-1-82165$ & FE $5 * 11$ & SC He 0I Flow Element & SCFM & MSLD & $\mathrm{NA}$ & & & $\mathrm{X}$ & \\
\hline 86 & $\mathrm{H}-1-82165$ & FIT 5*I1 & SC He 0l Flow Transmitter & SCFM & MSLD & $\mathrm{NA}$ & & & $\mathrm{X}$ & \\
\hline 87 & H-1-82165 & FE 5*50 & SC He 03 Flow Element & SCFM & MSLD & $\mathrm{NA}$ & & & $\mathrm{X}$ & \\
\hline 88 & H-1-82165 & FIT $5 * 50$ & SC He 03 Flow Transmitter & SCFM & MSLD & NA & & & $\mathrm{X}$ & \\
\hline 89 & H-1-82165 & PIT 5*09 & \begin{tabular}{|l} 
SC He 01 Pressure \\
Transmitter
\end{tabular} & PSIG & MSLD & NA & $\mathrm{X}$ & & & \\
\hline \multirow[t]{2}{*}{90} & H-1-82165 & PIT 5*48 & $\begin{array}{l}\text { SC He } 03 \text { Pressure } \\
\text { Transmitter }\end{array}$ & PSIG & MSLD & NA & $\mathrm{X}$ & & & \\
\hline & & & $\begin{array}{c}\text { HELIUM SUPPLY } \\
\text { VALVING } \\
\end{array}$ & & & & & & & \\
\hline 91 & H-l-82161 & $\mathrm{FV}-1 * 19$ & Helium Elow Valve & SCEM & MSLD & NA & & & $\mathrm{x}$ & \\
\hline
\end{tabular}


HNF-2402

Rev. 0

\section{APPENDIX F (Cont.) \\ CVD FIRST ARTICLE PRE-TEST INSTRUMENTATION CALIBRATION REPORT}

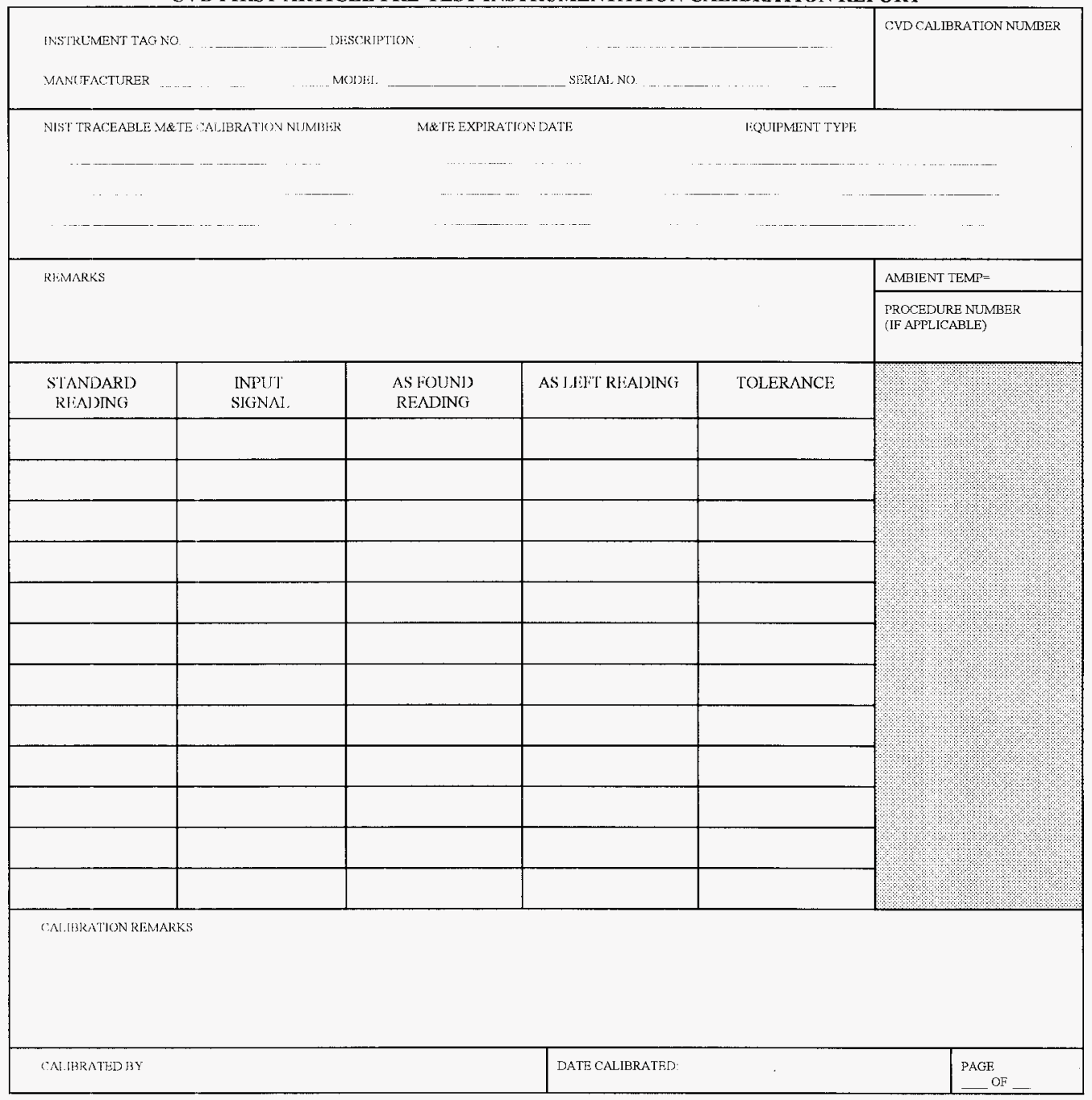




\begin{tabular}{|c|c|c|}
\hline \multicolumn{2}{|c|}{ PRE-JOB SAFETY MEETING FORM } & Page 1 of 2 \\
\hline \multicolumn{2}{|l|}{ Job Description/Title } & Date \\
\hline Work Package No.: & \multicolumn{2}{|l|}{ Person in Charge (PIC): } \\
\hline \multicolumn{3}{|l|}{ First Aid Qualified Person: } \\
\hline \multicolumn{3}{|l|}{ Check Items Discussed } \\
\hline II Procedures/Plans to be Used & \multicolumn{2}{|l|}{ No. } \\
\hline II Applicable OSR's & \multicolumn{2}{|l|}{ No. } \\
\hline II Radiation Work Permit & \multicolumn{2}{|l|}{ No. } \\
\hline II Job Hazard Analysis & \multicolumn{2}{|l|}{ No. } \\
\hline II Construction Permit (as needed) & \multicolumn{2}{|l|}{ No. } \\
\hline $\begin{array}{l}\text { II Additional Permits (i.c., confined } \\
\text { space, excavation, etc.) }\end{array}$ & \multicolumn{2}{|l|}{ No. } \\
\hline \multicolumn{3}{|c|}{ [] Revicw All Applicable Safety Precautions and Prestart Conditions per Procedures/Plans to be used } \\
\hline \multicolumn{3}{|l|}{ [] Components Locked and Tagged } \\
\hline \multicolumn{3}{|c|}{ [] ALARA Considerations (applicable MSDS's) } \\
\hline \multicolumn{3}{|c|}{ Il Respiratory Protection (fresh air, PAPR's, chemical filters, etc.) } \\
\hline \multicolumn{3}{|c|}{ Il Radioactive Contamination Containment Device } \\
\hline \multicolumn{3}{|l|}{ II Emergency Response and Actions } \\
\hline \multicolumn{3}{|l|}{ II Summary of Job Sequence (or steps) } \\
\hline \multicolumn{3}{|c|}{ II Work Area Conditions (high/low temperatures, lighting, ete.) } \\
\hline \multicolumn{3}{|c|}{ II All Equipment Functionally Checked and at Work Site } \\
\hline \multicolumn{3}{|l|}{ Special Circumstances or COMMENTS: } \\
\hline \multicolumn{3}{|l|}{ Chairman Signature: } \\
\hline \multicolumn{3}{|l|}{ Operations } \\
\hline \multicolumn{3}{|l|}{ Maintenance } \\
\hline \multicolumn{3}{|l|}{ Other } \\
\hline
\end{tabular}


HNF-2402

Rev. 0

Pre-Job Safety Meeting Form

ATTENDANCE ROSTER

Page 2 of 2

Name

Org. Code

Payroll No. 
HNF-2402

Rev. 0

APPENDIX H

SIGNATURE VERIFICATION DATA SHEET

Instructions: Anyone entering their signature or initials in this test procedure must complete the information below.

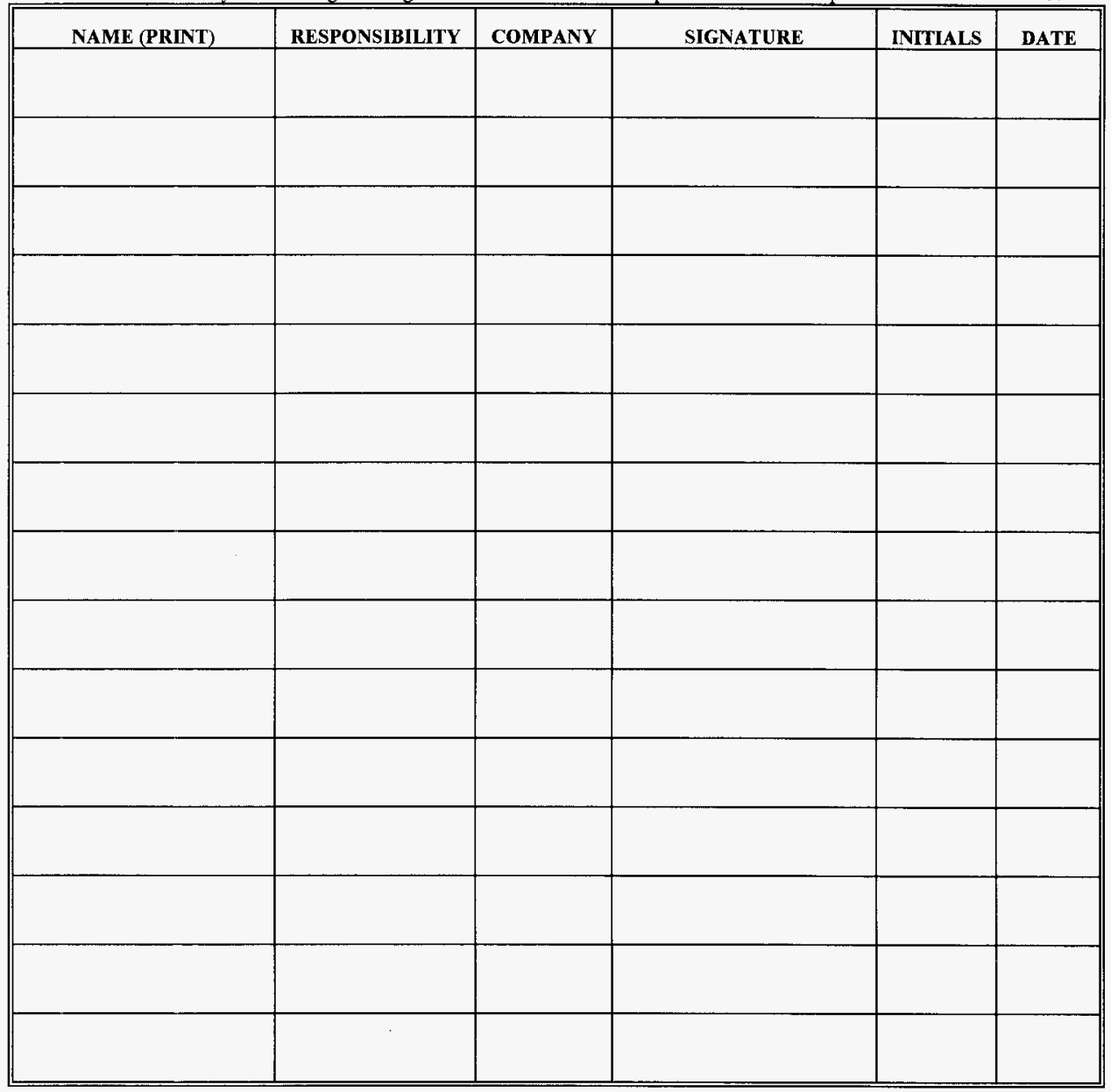


$\mathrm{HNF}-2402$

Rev. 0

\section{APPENDIX I}

LEAK TEST PROCEDURES AND TEST REPORTS

\begin{tabular}{|c|c|c|c|c|c|}
\hline Test \# & Test Engincer & Datc & $\begin{array}{l}\text { Section } \\
\text { number }\end{array}$ & Leak Rate Results & NDE Technician \\
\hline & & & & & \\
\hline & & & & & \\
\hline & & & & & \\
\hline & & & & & \\
\hline & & & & & \\
\hline & & & & & \\
\hline & & & & & \\
\hline & & & & & \\
\hline & & & & & \\
\hline & & & & & \\
\hline & & & & & \\
\hline & & & & & \\
\hline & & & & & \\
\hline & & & & & \\
\hline & & & & & \\
\hline & & & & & \\
\hline & & & & & \\
\hline & & & & & \\
\hline & & & & & \\
\hline
\end{tabular}


HNF-2402

Rev. 0

APPENDIX J

FIGURES

J-1 


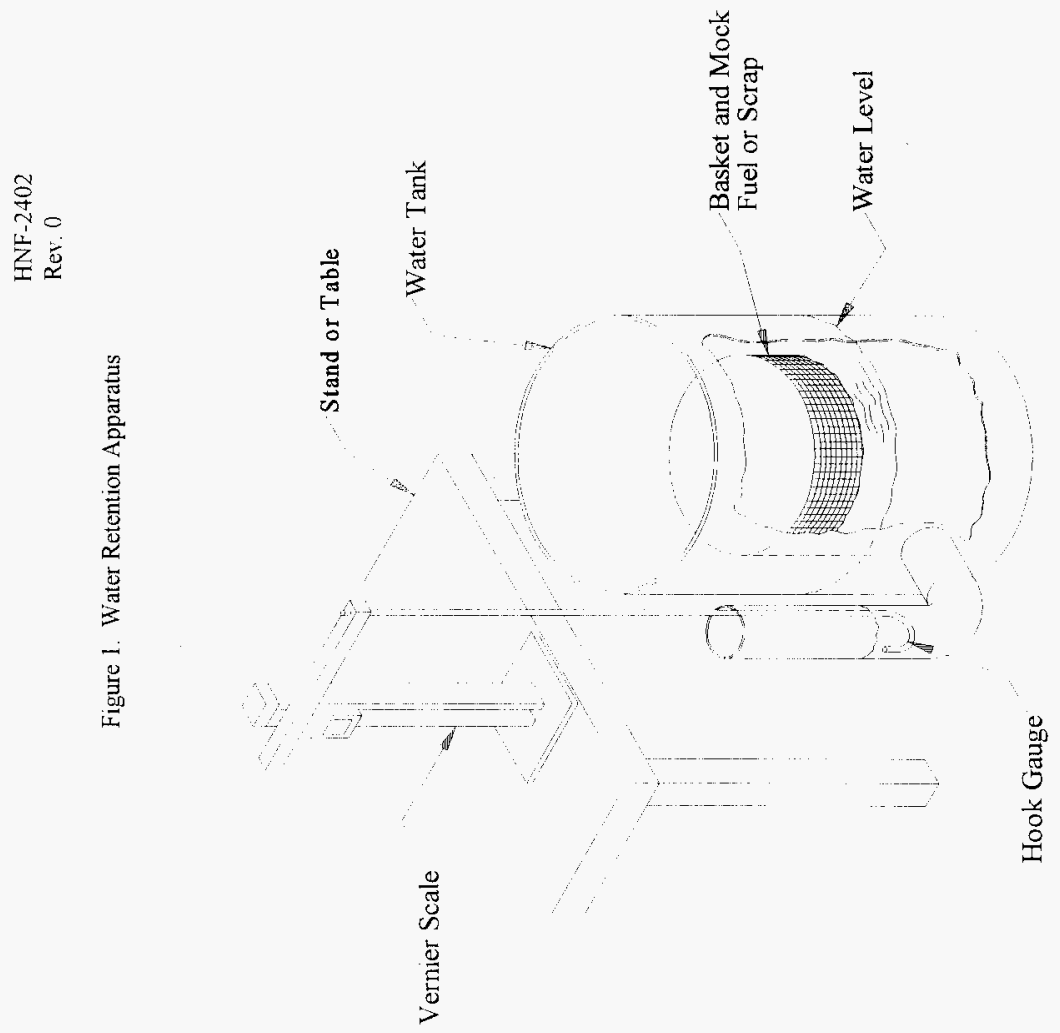

$\stackrel{ }{\longrightarrow}$ 
草。
岌它
至

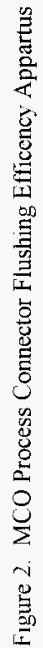

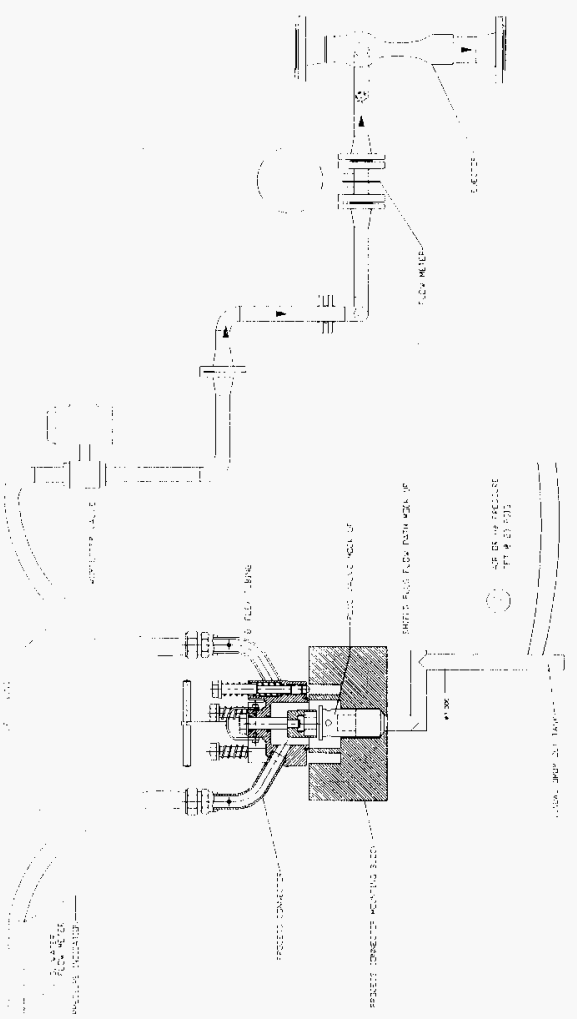




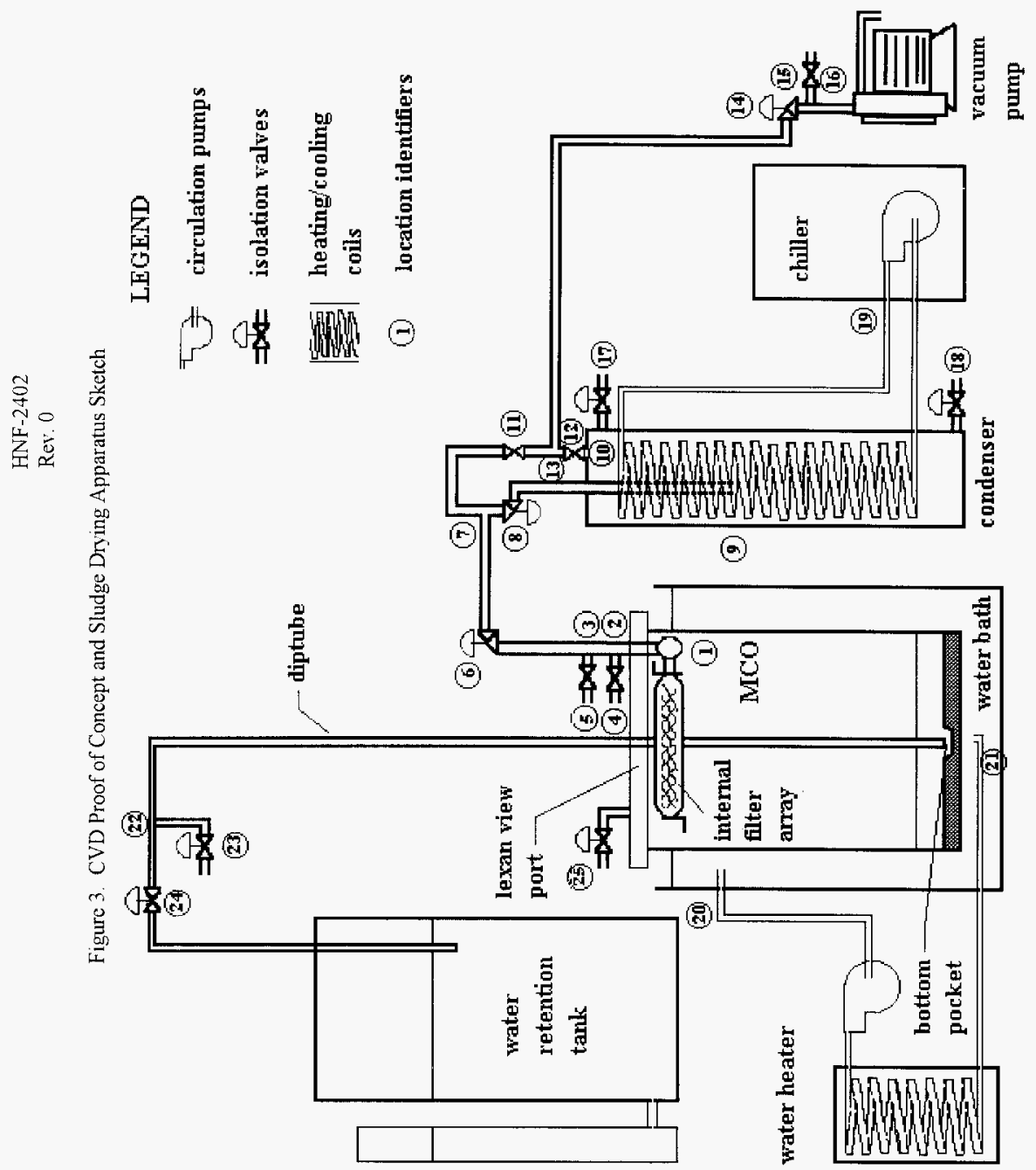




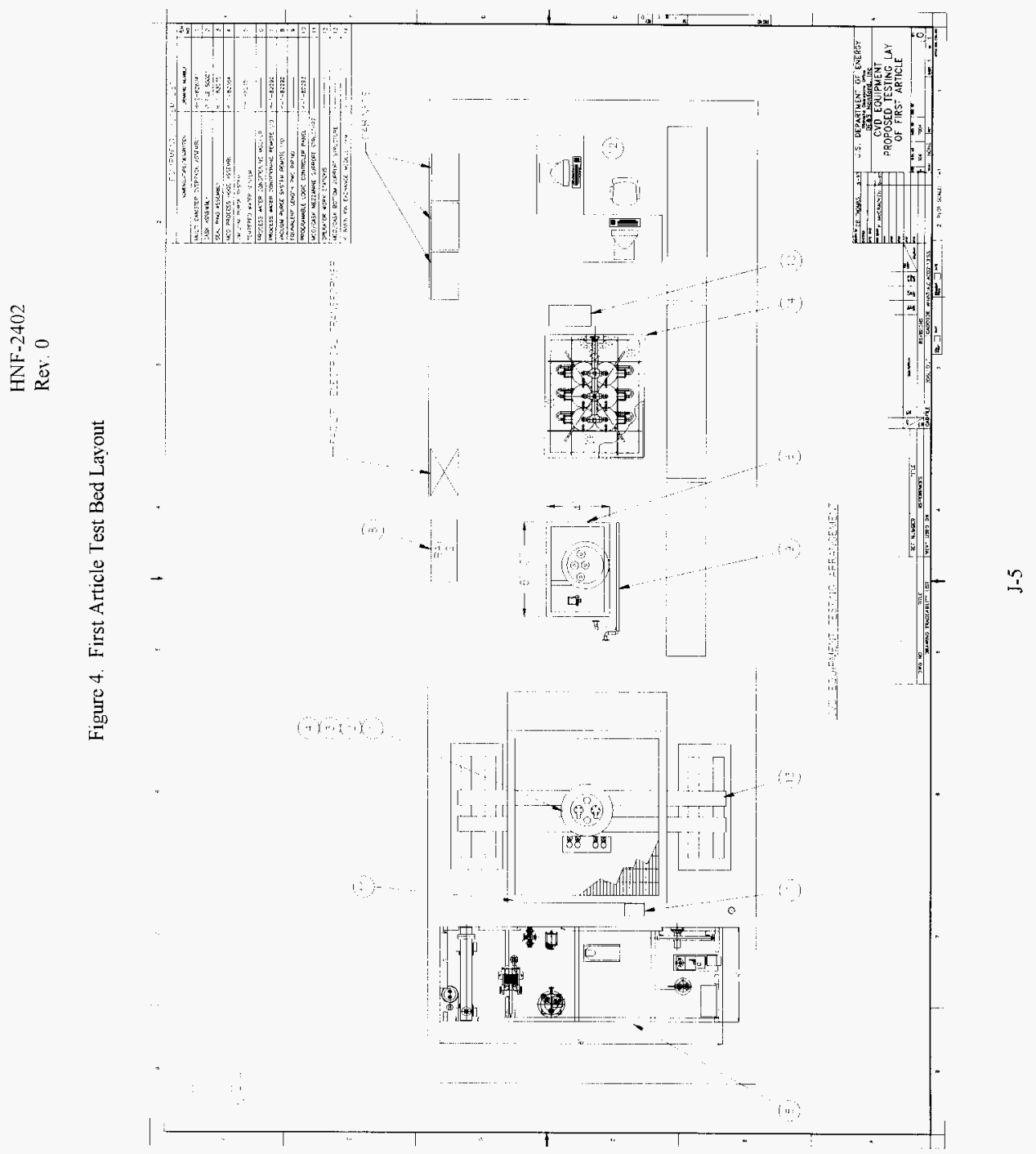




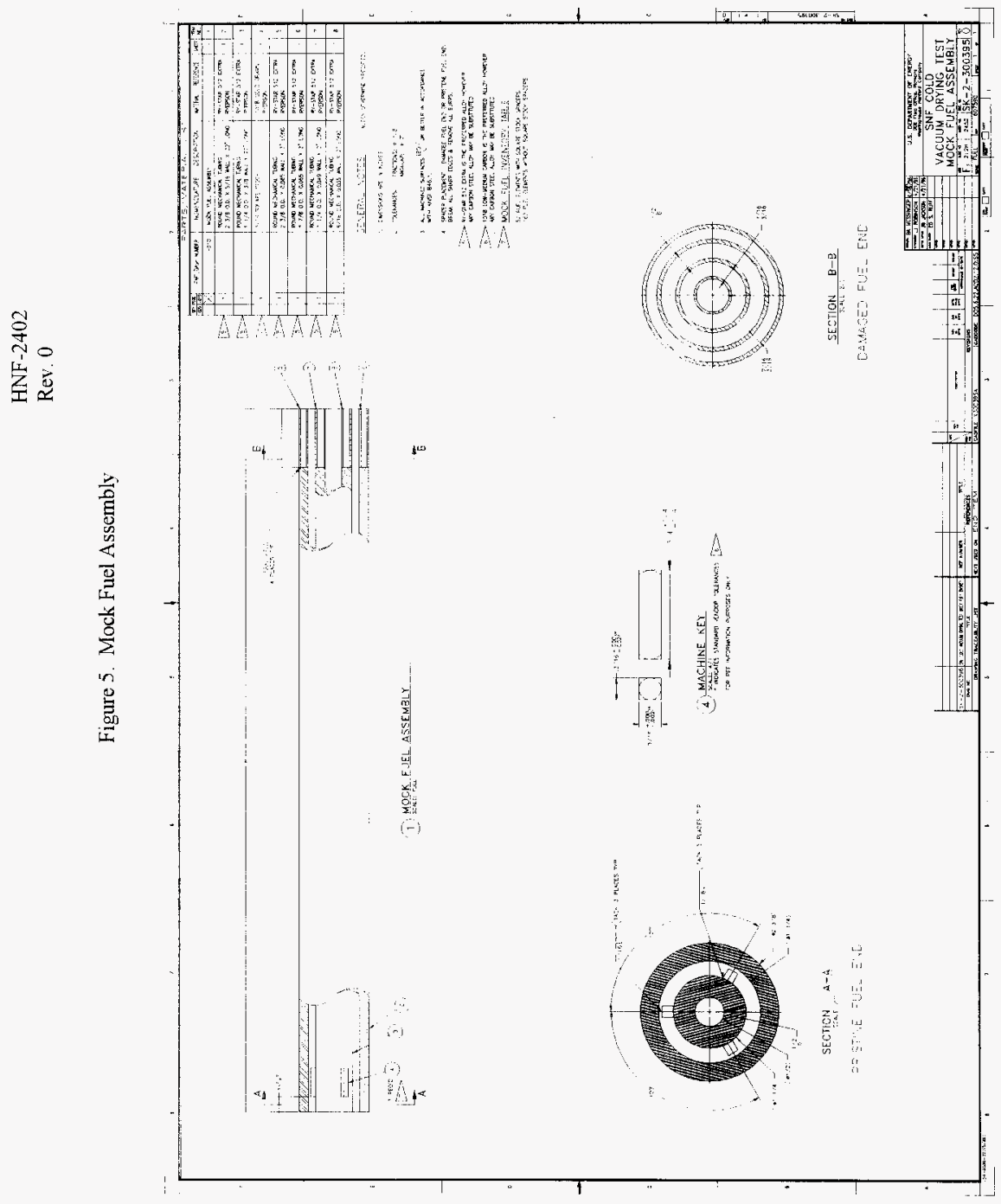


Figure 6. Mixed Fuel Basket Layout

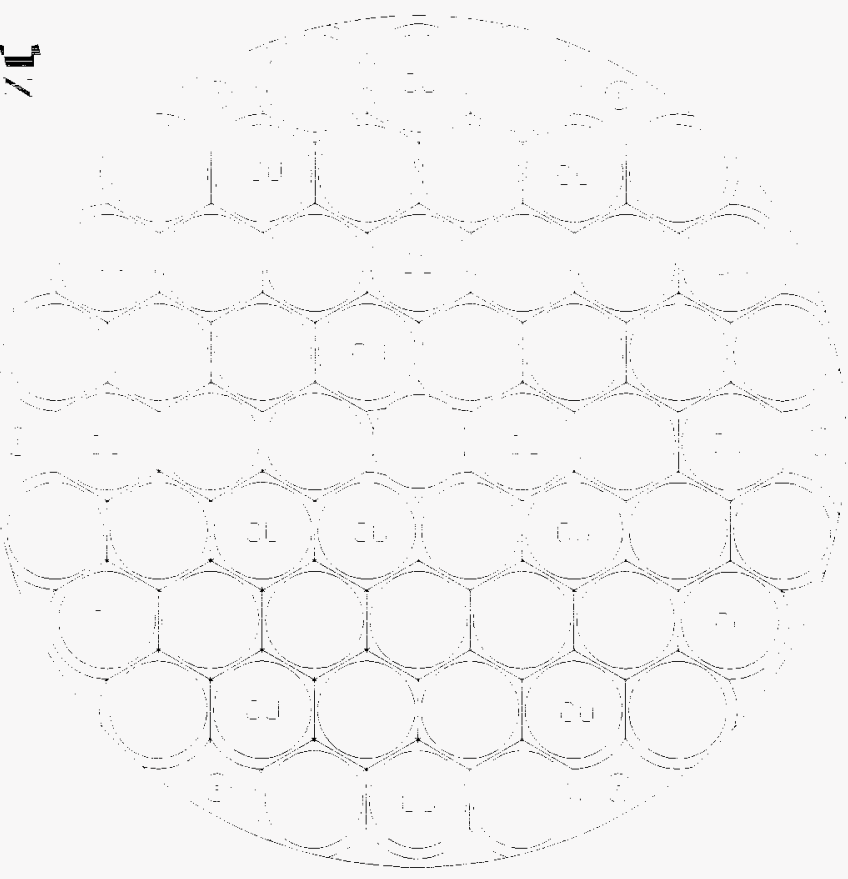

\section{NOTE : $\quad$ CU is "Cavities Up.}

For each additional stacked basket--rotate baskets in 20 degree increments counter clockwise in the MCO. 


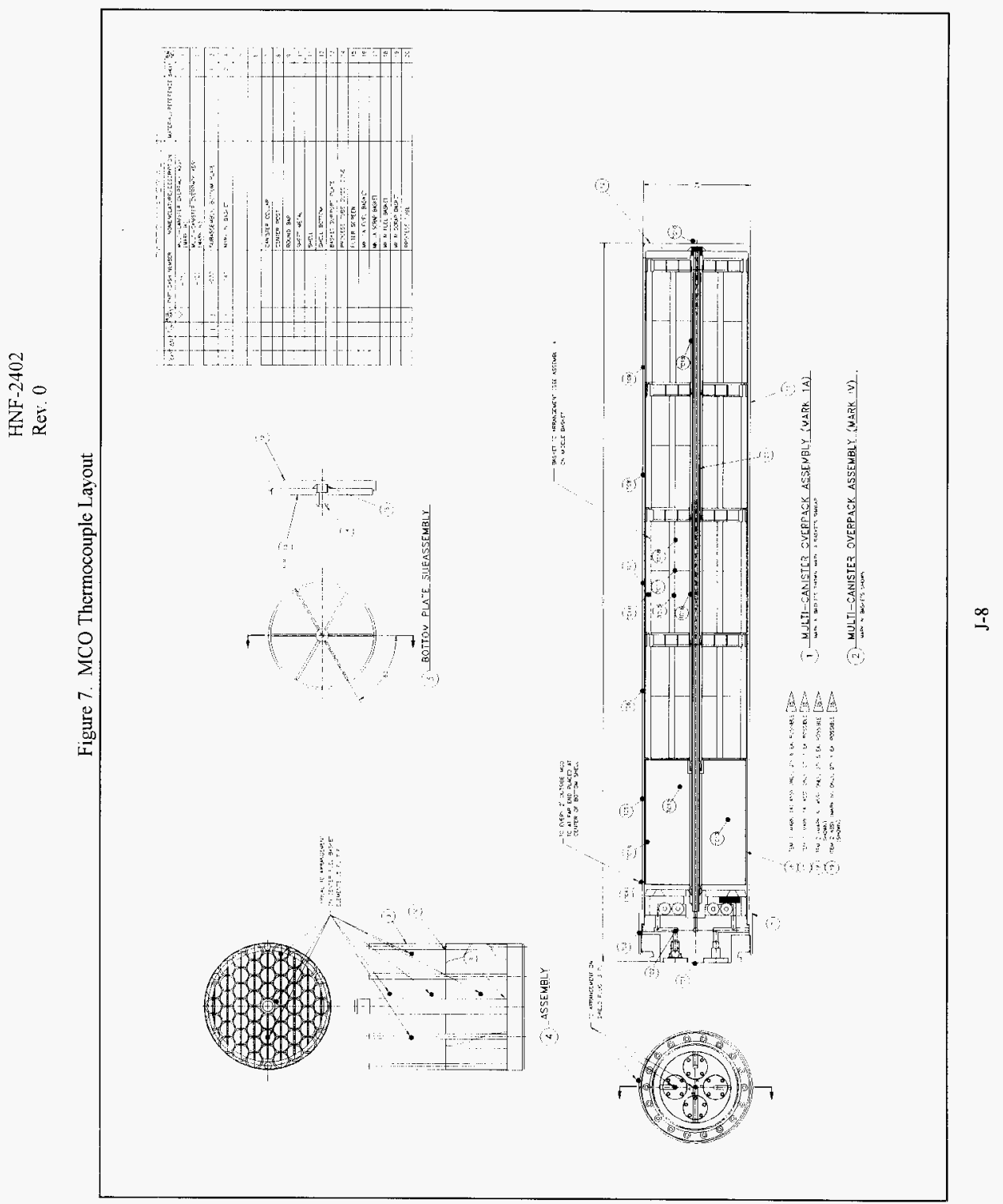


Figure 8. Composite System P \& ID

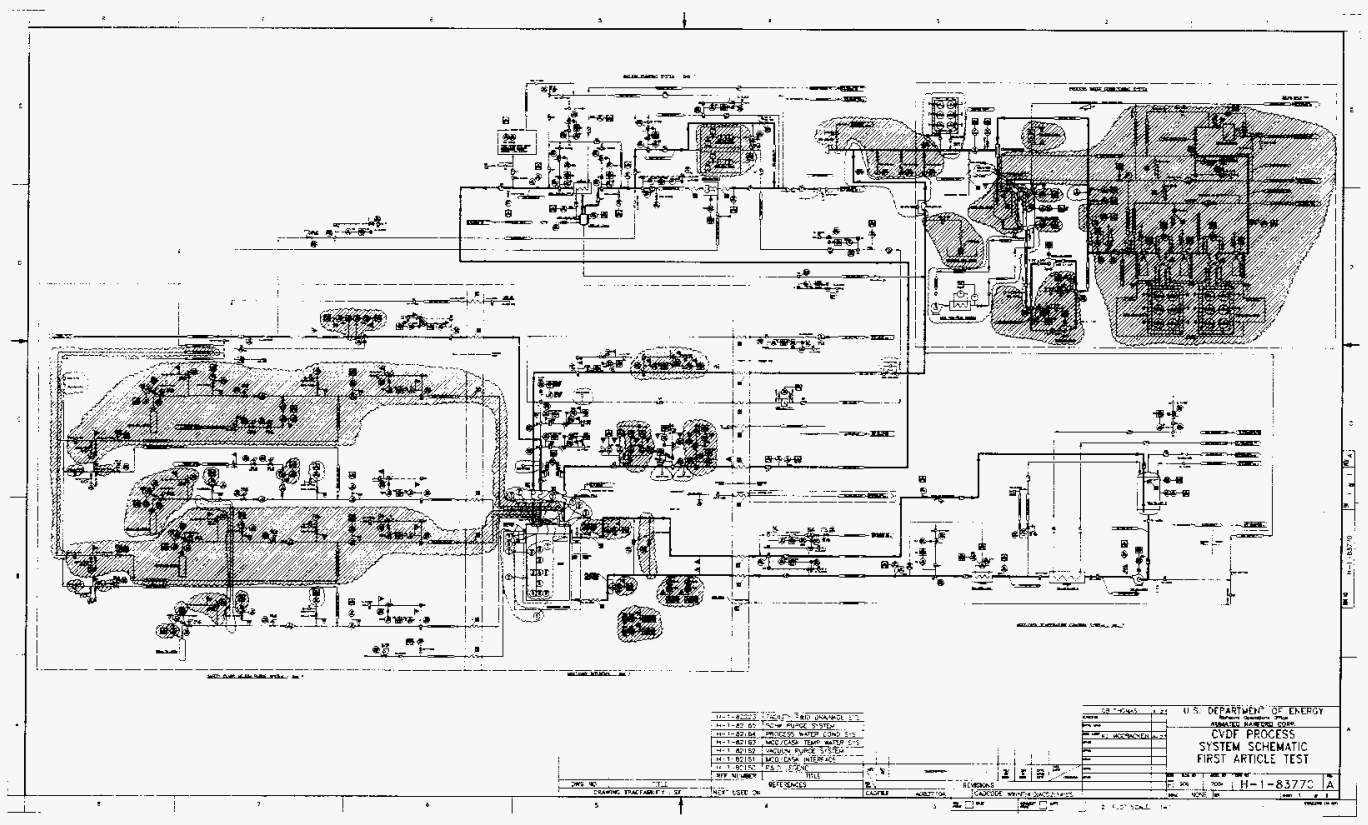




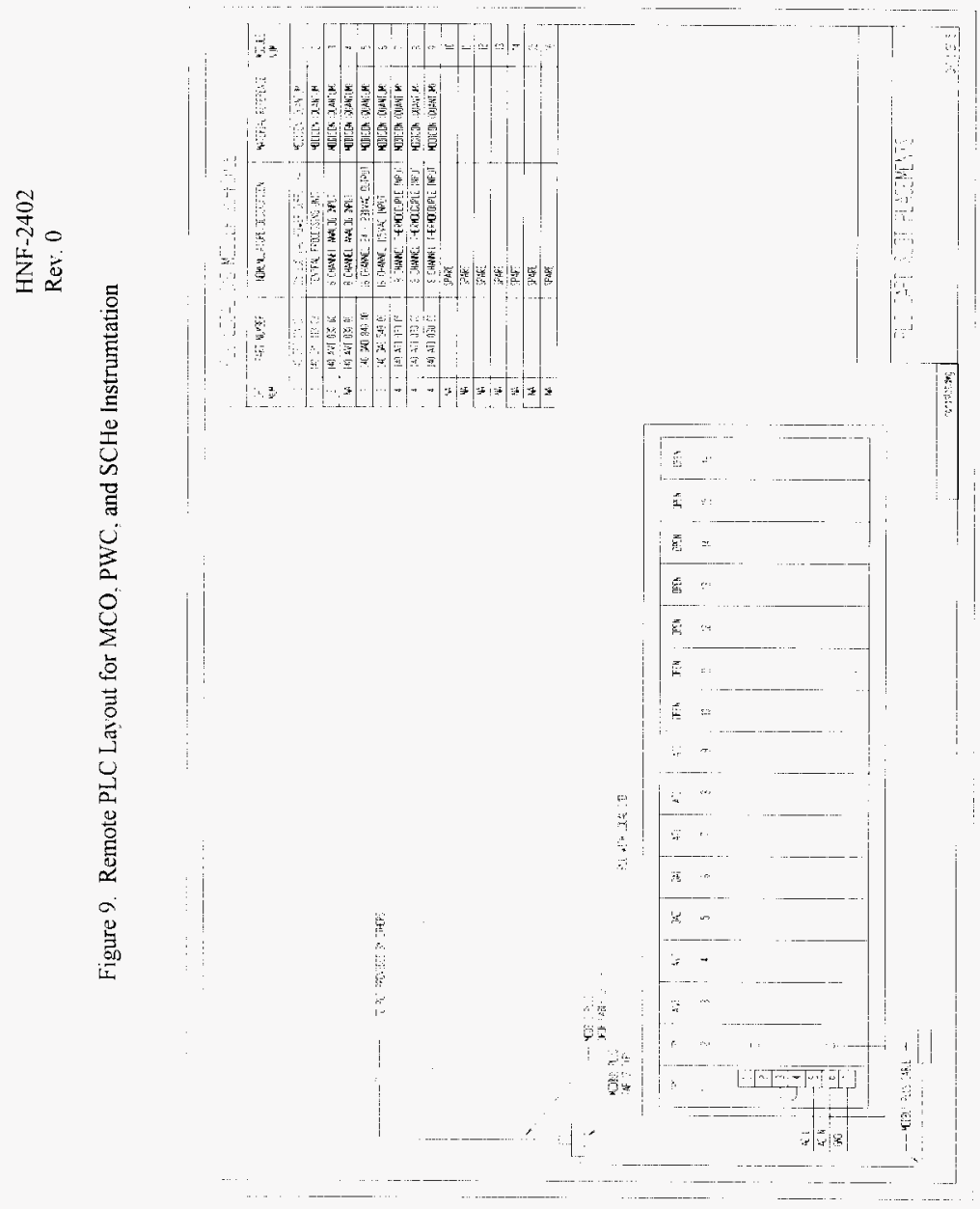

$\stackrel{ }{1}$ 


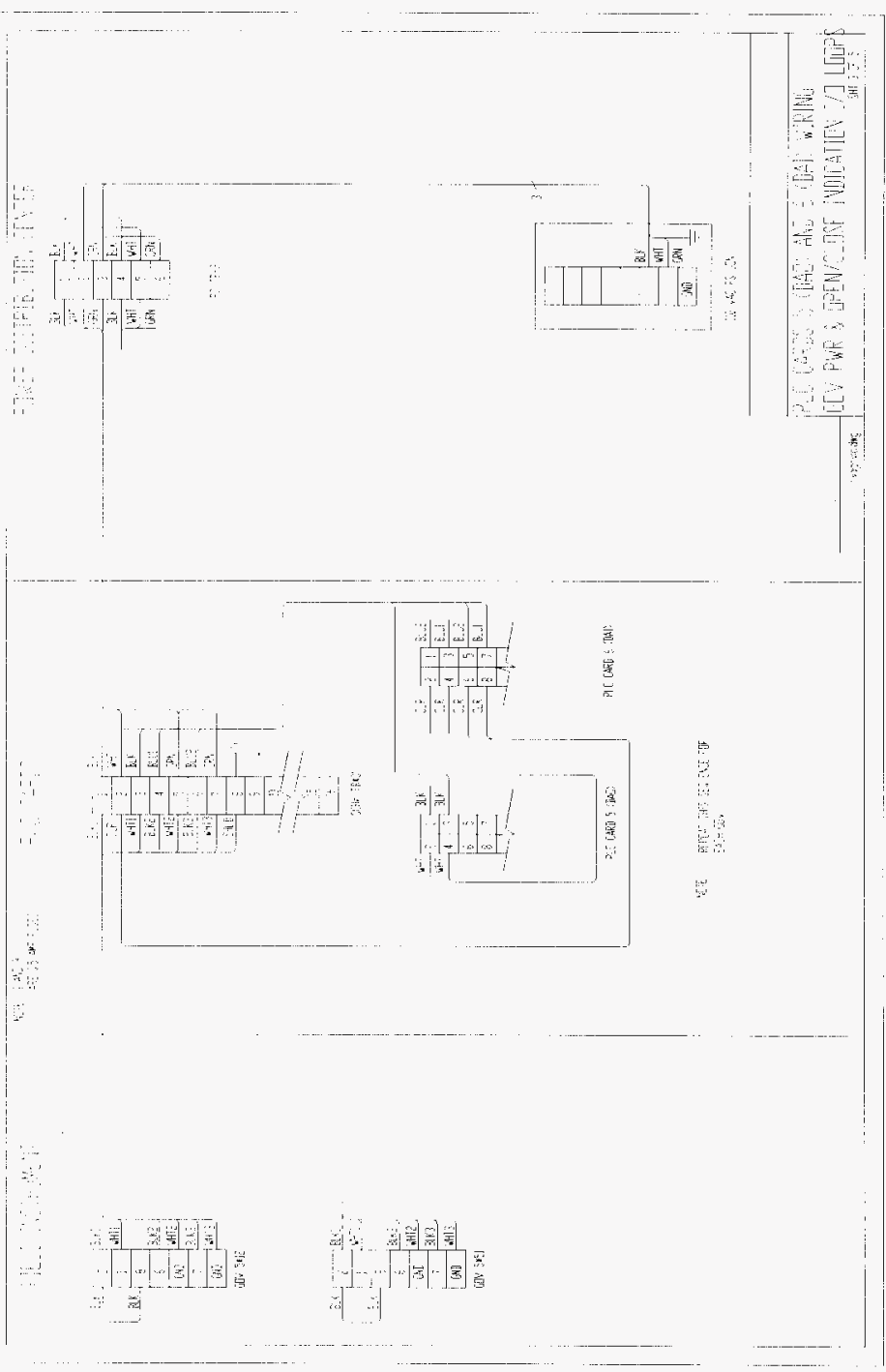

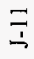




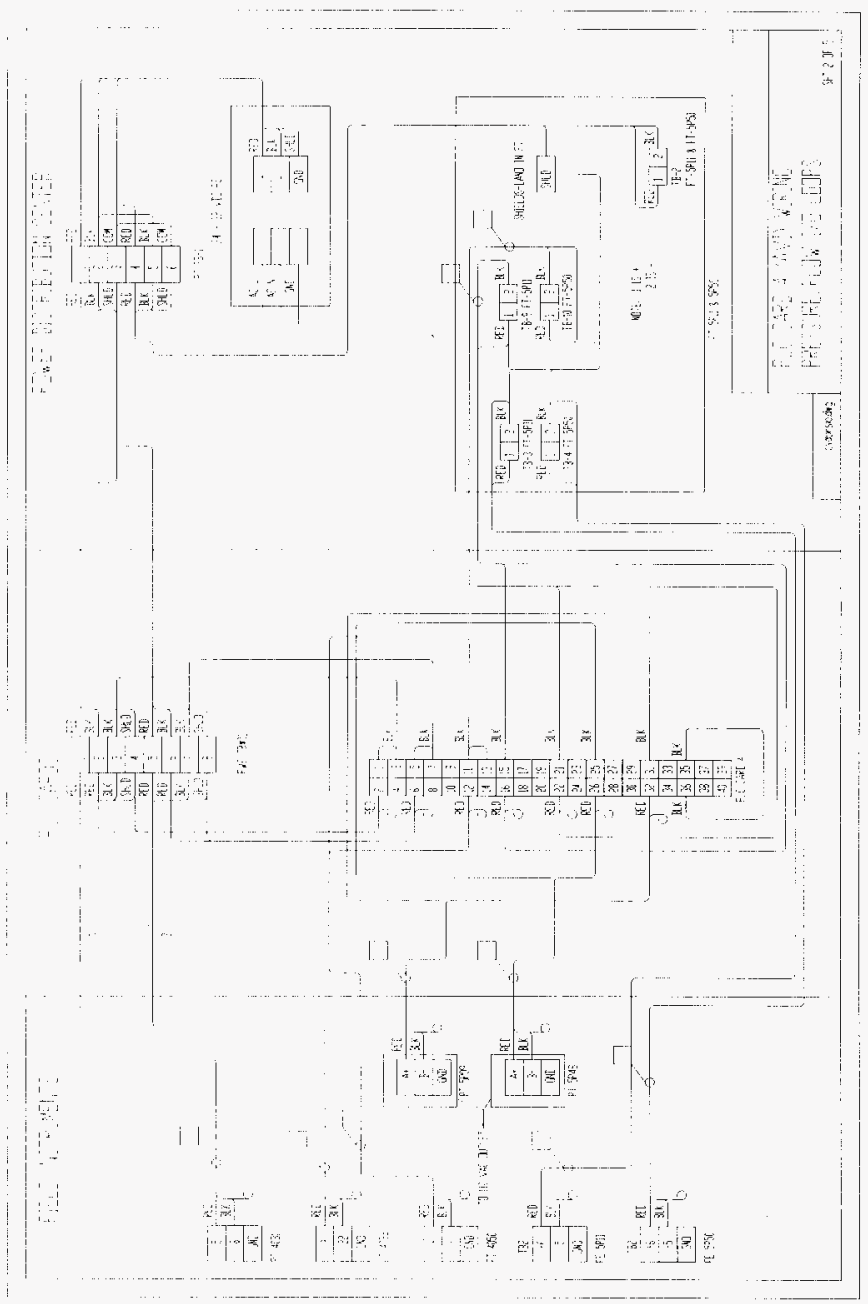




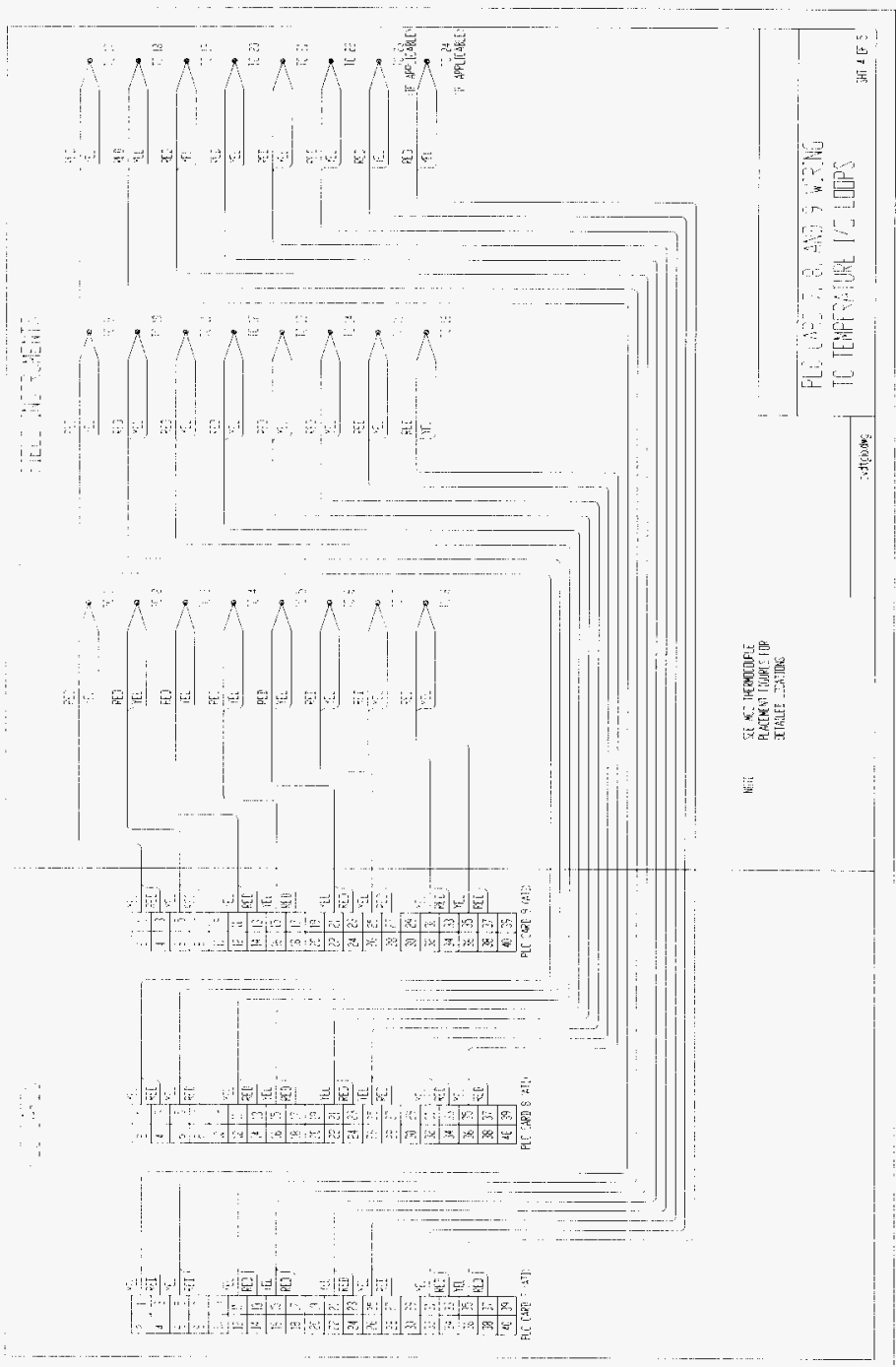

$\stackrel{m}{\leftrightarrows}$ 


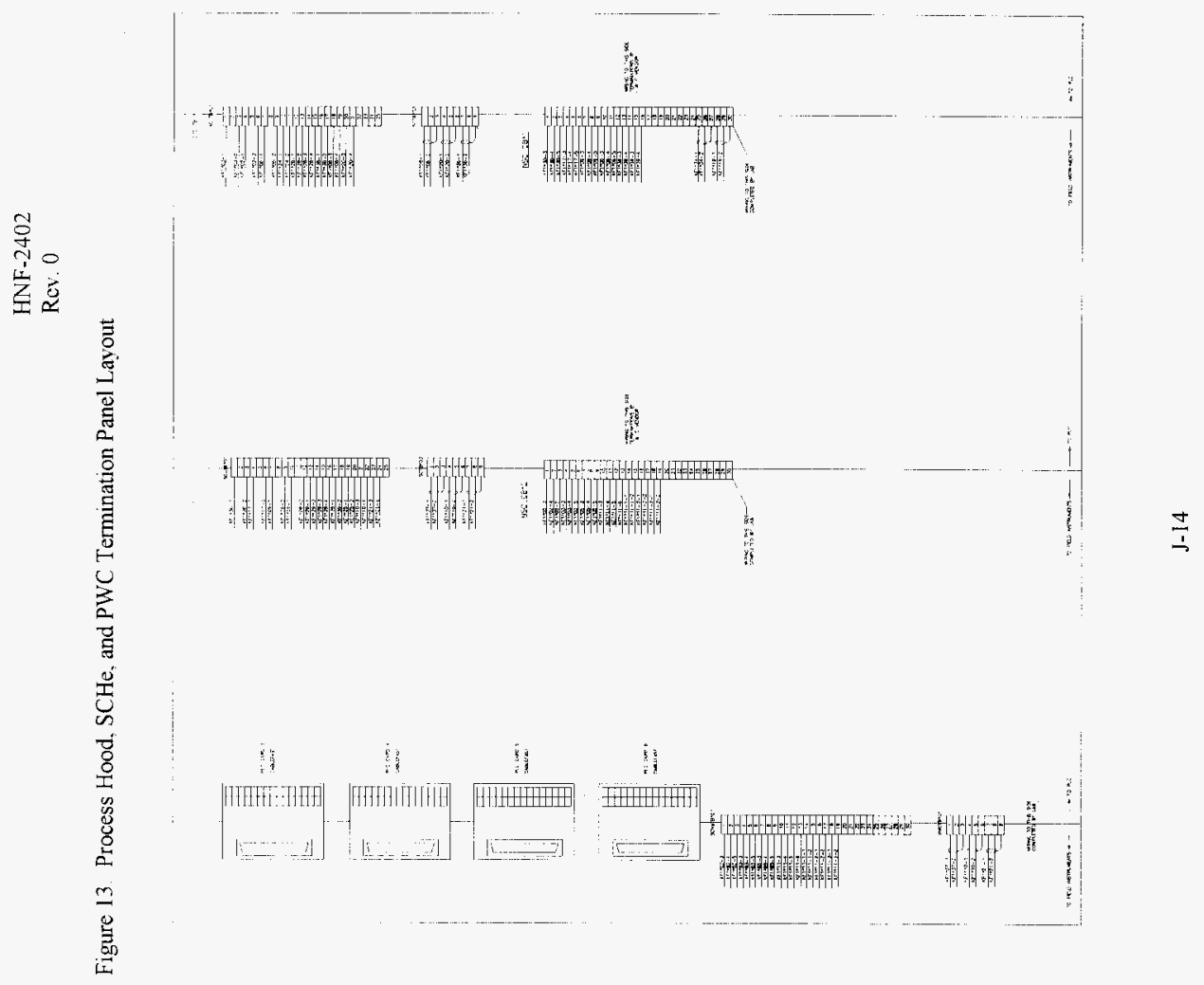


鄯敦

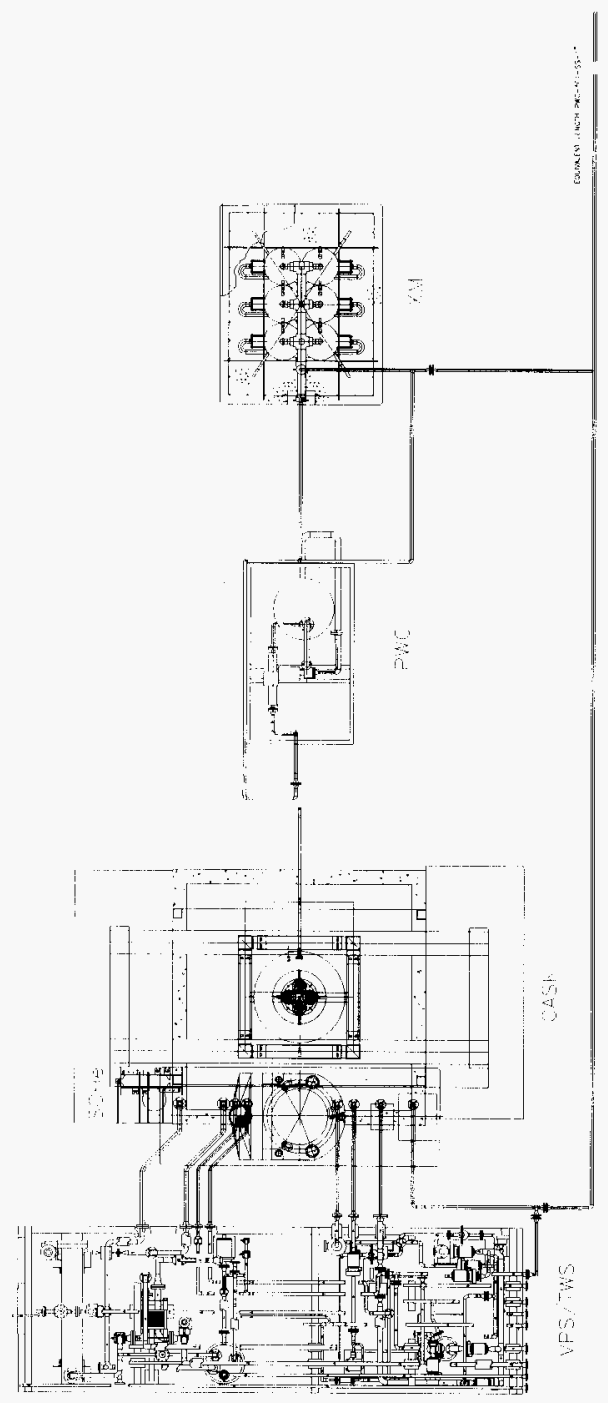

$\frac{n}{1}$ 


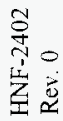

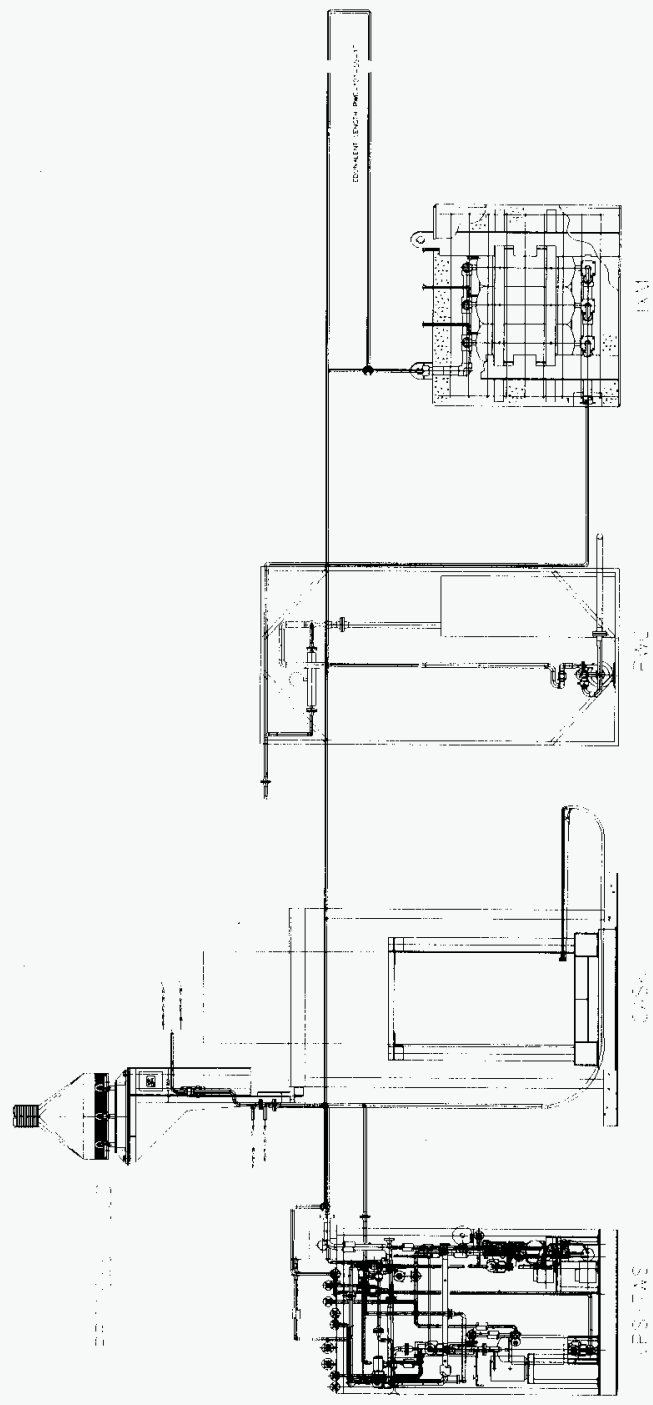

$\stackrel{0}{\leftrightarrows}$ 